



\section{Developing GHG mitigation strategies for agro-sectors: feasibility study for the dairy sector}

Beldman, A.C.G. ${ }^{1}$, Lesschen, J.P. ${ }^{1}$, Vellinga, Th. ${ }^{1}$, Pishgar Komleh, H. ${ }^{1}$, Boone, $\mathrm{K} .^{1}$, Blonk, $\mathrm{H} .^{2}$, Scholten, J. ${ }^{2}$

1 Wageningen University \& Research

2 Blonk Consultants

This study was carried out by Wageningen University \& Research and Blonk Consultants and financed by Rabobank

Wageningen Economic Research

Wageningen, September 2021

REPORT

2021-105

ISBN 978-94-6395-992-6 
Beldman, A.C.G., Lesschen, J.P., Vellinga, Th., Pishgar Komleh, H., Boone, K., Blonk, H., Scholten, J., 2021. Developing GHG mitigation strategies for agro-sectors: feasibility study for the dairy sector. Wageningen, Wageningen Economic Research, Report 2021-105. 68 pp.; 12 fig.; 6 tab.; 104 ref.

De financiële sector kan en wil een rol spelen in het verlagen van de emissie van broeikasgassen in de agro-sectoren. Rabobank heeft opdracht gegeven voor een haalbaarheidsstudie naar drie kernpunten van een gezamenlijke benadering voor de internationale financiële sector: (1) methodologie voor vaststellen van doelen voor reductie van broeikasgasemissies; (2) het schatten van huidige emissies om monitoring mogelijk te maken en (3) het identificeren van opties om emissies broeikasgassen te reduceren. Dit rapport geeft een overzicht van de beschikbare literatuur rond deze punten. Een hoofdconclusie van het rapport is om waar mogelijk af te stemmen met sectorale of nationale doelen en programma's.

The financial sector can and wants to play an important role in contributing to the reduction of GHG emissions in agro-sectors. Rabobank commissioned a feasibility study to assess the possibilities and challenges for what is seen as three key-elements of a joint approach for the international financial sector: (1) methodologies for setting GHG emission targets; (2) estimation of current emissions for monitoring purposes; and (3) identification of mitigation options. This report gives an overview of available literature on these elements. A main conclusion of the report is to align where possible with sectoral or national GHG targets and tools of programmes.

Key words: greenhouse gas, mitigation strategies, dairy

This report can be downloaded for free at https://doi.org/10.18174/553850 or at www.wur.eu/economic-research (under Wageningen Economic Research publications).

(C) 2021 Wageningen Economic Research

P.O. Box 29703, 2502 LS The Hague, The Netherlands, T +31 (0)70 33583 30,

E communications.ssg@wur.nl, http://www.wur.eu/economic-research. Wageningen Economic Research is part of Wageningen University \& Research.

\section{(cc) BY-NC}

This work is licensed under a Creative Commons Attribution-Non Commercial 4.0 International License.

(C) Wageningen Economic Research, part of Stichting Wageningen Research, 2021

The user may reproduce, distribute and share this work and make derivative works from it. Material by third parties which is used in the work and which are subject to intellectual property rights may not be used without prior permission from the relevant third party. The user must attribute the work by stating the name indicated by the author or licensor but may not do this in such a way as to create the impression that the author/licensor endorses the use of the work or the work of the user. The user may not use the work for commercial purposes.

Wageningen Economic Research accepts no liability for any damage resulting from the use of the results of this study or the application of the advice contained in it.

Wageningen Economic Research is ISO 9001:2015 certified.

Wageningen Economic Research Report 2021-105 | Project code 2282300474

Cover photo: Shutterstock 


\section{Contents}

Preface

$\begin{array}{lll}1.1 & \text { Goal and approach of the project } & 7\end{array}$

$\begin{array}{lll}1.2 & \text { Dairy sector and GHG emissions } & 7\end{array}$

1.3 Target setting $\quad 8$

1.4 Monitoring emissions of farms 9

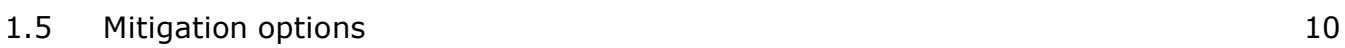

$\begin{array}{ll}1.6 & \text { Overall conclusions } \\ \end{array}$

1.1 Doel en werkwijze van het project $\quad 12$

1.2 Zuivelsector en broeikasgasemissies $\quad 12$

$\begin{array}{lll}1.3 & \text { Doelstelling } & 13\end{array}$

$\begin{array}{lll}1.4 & \text { Uitstootmonitoring van agrarische bedrijven } & 14\end{array}$

$\begin{array}{lll}1.5 & \text { Klimaatmaatregelen } & 16\end{array}$

$\begin{array}{lll}1.6 & \text { Algemene conclusies } & 16\end{array}$

$\begin{array}{lll}2.1 & \text { Introduction } & 17\end{array}$

$\begin{array}{ll}2.1 .1 \text { Policy context } & 17\end{array}$

2.1.2 What makes the agricultural sector different? 18

$\begin{array}{ll}2.1 .3 \text { Sector initiatives } & 18\end{array}$

2.1.4 Science based targets setting 19

$\begin{array}{ll}2.1 .5 \text { Objective } & 19\end{array}$

$\begin{array}{lll}2.2 & \text { Approach for setting targets } & 20\end{array}$

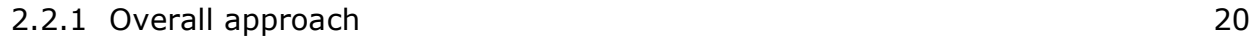

2.2.2 Setting an overall reduction target $\quad 20$

2.2.3 Determining a fair share for the dairy sector 21

2.2.4 Determining the scope and system boundary for the reduction
target

2.2.5 How to get to national sectoral or farm level targets 26

$\begin{array}{ll}2.2 .6 & \text { Type of reduction target } \\ & 27\end{array}$

$\begin{array}{lll}2.3 & \text { Recommendations } & 28\end{array}$

$\begin{array}{lll}3.1 & \text { Introduction } & 30\end{array}$

3.2 Most relevant methodological guidelines for the dairy industry 30

$\begin{array}{lll}3.3 & \text { Results of tools and data availability investigation } & 31\end{array}$

3.3.1 New Zealand 31

3.3.2 United States $\quad 33$

$\begin{array}{ll}3.3 .3 \text { Australia } & 34\end{array}$

3.3.4 The Netherlands $\quad 35$

3.3.5 Non-regional specific tools 36

$\begin{array}{lll}3.4 & \text { Strategic selection and use of monitoring tools } & 37\end{array}$

$\begin{array}{ll}3.4 .1 & \text { Baseline tool }\end{array}$

$\begin{array}{ll}3.4 .2 \text { Monitoring } & 38\end{array}$ 
$\begin{array}{lll}4.1 & \text { Introduction } & 43\end{array}$

4.2 Animal production (enteric fermentation) $\quad 45$

$\begin{array}{lll}4.3 & \text { Animal management } & 47\end{array}$

$\begin{array}{lll}4.4 & \text { Feed production } & 48\end{array}$

$\begin{array}{lll}4.5 & \text { Manure management } & 49\end{array}$

4.5.1 Introduction $\quad 49$

4.5.2 In-barn techniques $\quad 50$

4.5.3 Intermediate techniques 53

4.5.4 Application of manure $\quad 54$

4.6 Green energy $\quad 55$

4.7 Factors influencing the selection of GHG mitigation actions $\quad 55$

$\begin{array}{lll}4.8 & \text { Relation to GHG monitoring stage } & 60\end{array}$

References and websites 


\section{Preface}

Climate change and the reduction of greenhouse gas emissions (GHG) is one of the most import challenges for companies in the agro supply chains. The financial sector can and wants to play an important role in contributing to the solution of this problem. Rabobank is working on an initiative in which banks and financial institutions collaborate to organise this. As a first step Rabobank commissioned a feasibility study to assess the possibilities of a joint approach for the financial sector.

We are thankful for the guidance and support in this project by a Rabobank team consisting of Michel van den Berg, Alexandre Dumitru and Marian van Riel. The project was executed by a joint project team from Wageningen University \& Research and Blonk Consultants.

Prof.dr.ir. J.G.A.J. (Jack) van der Vorst General Director Social Sciences Group (SSG)

Wageningen University \& Research 


\section{$1 \quad$ Summary and synthesis}

\subsection{Goal and approach of the project}

Climate change and the reduction of greenhouse gas emissions (GHG) is one of the most import challenges for companies in the agro supply chains. Agro-chains produce a significant amount of total GHG emissions in the world but could also play an important role in reducing emissions. In most agro supply chains a large share of the emissions takes place at farm level, but this does not mean that it is just up to the farmers to solve the problem. The financial sector can and wants to play an important role in contributing to the solution of this problem. Rabobank is working on an initiative in which banks and financial institutions collaborate to organise this.

As a first step Rabobank commissioned a feasibility study to assess the possibilities and challenges for what is seen as three key elements of a joint approach for the financial sector:

- Methodologies for setting up GHG emission targets and a pathway towards these targets for different agro-sectors

- An estimation of current emissions, both on client (starting with farms) and portfolio level in order to be able to monitor progress

- Identification of mitigation options in order to be able to provide support for farmers and other sector players in mitigating GHG emissions.

The study is a limited study. The study is executed for the dairy sector and four countries (Netherlands, New Zealand, Australia and USA) have been selected as a pilot. The overall purpose is to collect input for an approach that can be used by the financial sector to monitor and work on the reduction of greenhouse gas emissions in agricultural sectors and on a global level. The three elements mentioned above have been studied separately through literature review, with limited attention for overall synthesis. The study was executed by Wageningen University \& Research and Blonk Consultants. The study was executed from July until December 2020.

\subsection{Dairy sector and GHG emissions}

Regarding greenhouse gas emissions, the dairy sector and agriculture in general are different and more complicated than many other sectors (Chapter 2.1). First, the production of dairy (and agriculture in general) is based on biological processes, of which some lead inevitably to emissions, like the methane emission of ruminants. These biological processes are also complicated to control in detail because they can depend on e.g. weather circumstances. Second, the emission profile of dairy farms is complex. A relevant share of the emissions is upstream (e.g. in inputs as feed and fertiliser) and the emissions are divided over $\mathrm{CH}_{4}, \mathrm{CO}_{2}$ and $\mathrm{N}_{2} \mathrm{O}$. There are a large number of mitigation options, but each option contributes relatively little to the overall reduction (Chapter 4). Moreover, the impact of mitigation options depends on and is influenced by many variable biological factors. The more complex GHG profile also implies that quite detailed data is required to assess GHG emissions at farm level, especially if the goal is to give farm-specific advice on fitting mitigation options. Availability and access to data for monitoring GHG emissions at farm level is a challenge (Chapter 3). Third, it is important to be aware of the fact that the dairy sector relates to more sustainability topics than climate change: e.g. water use and quality, biodiversity and animal welfare. So, it is important to beware of trade-offs and ensure an integrated approach towards the dairy farmers (Chapter 4).

This does not mean it is not possible to achieve progress in GHG mitigation in the dairy sector. On the contrary: Many mitigation options are available and several studies show reduction can be achieved (Chapter 4). Many programmes in the dairy sector have shown that progress on specific topics can be 
achieved if a good plan with the right incentives and alignment with the relevant stakeholders is in place (Reijs et al., 2021).

\subsection{Target setting}

The following steps or choices have to be made in order to define a target (Chapter 2.2):

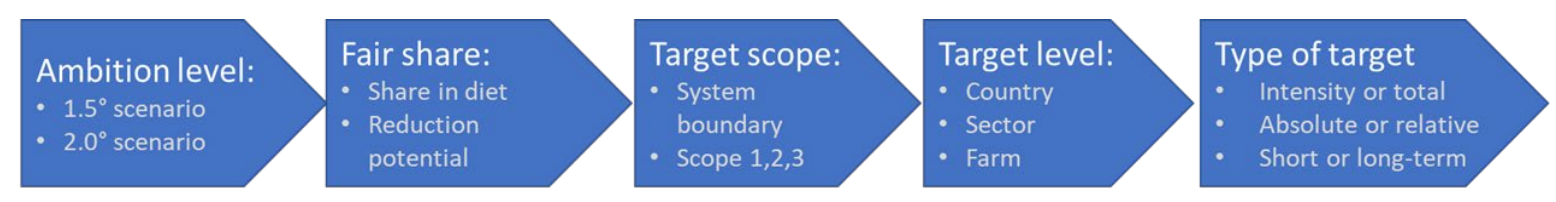

A general approach for science-based target setting is available, that is also relevant for agriculture and forestry. A key barrier for reporting on agriculture, forestry and land use is the lack of available standards. The Science Based Target initiative is working on this in the SBTi FLAG project. It is important to include land use change and carbon sequestration since those play a relevant role in GHG calculations in the dairy sector as in most other agricultural sectors.

For the Netherlands and New Zealand GHG national targets (agreement between government and sector) have been set for the overall livestock sector. In Australia and the USA, the dairy sector has set its own targets. Some individual dairy companies have set their own targets. One complicating factor is the difference in scope between the different targets. Dairy companies and sometimes also the dairy sector often work with cradle-to-factory scope (LCA product footprint) and national targets are linked to the national inventories, which are based on the IPCC emission sectors. The emissions from the IPCC emission sector agriculture only comprise the non- $\mathrm{CO}_{2}$ emissions from enteric fermentation, manure management and direct and indirect $\mathrm{N}_{2} \mathrm{O}$ soil emissions. It is important to be aware of these differences and take them into account in the overall approach.

It is complicated to check if sector targets are in line with the Paris Agreement, because national plans are usually not made sector by sector and only the national programme is assessed on alignment. The second complicating factor is that within the approach of the Paris Agreement the idea is that progress is assessed every five years (stock take) based on which countries should provide an updated National Determined Contribution (NDC) with a more ambitious reduction target.

Basically two scenarios are possible if the financial sector wants to work with targets:

1. A regional or national sector target is available.

If a national or sectoral target is available, this study recommends the financial sector work in alignment with these targets. The main advantage is that direct action is possible. For the studied cases specific targets for the dairy sector have been set. Disadvantages are that different regions will have different targets and it is uncertain that each regional sector target is in line with the Paris Agreement. The last point can be followed up by the action to assess the alignment with Paris and depending on the result interact with relevant stakeholders about updating the target.

2. A regional or national sector target is not available.

If a regional or national sector target is not available this study recommends the financial sector start with a prioritisation of relevant sectors and regions, based on the impact (in terms of emissions level and reduction potential) that can be made. This is preferably followed by the step to develop targets in interaction with relevant stakeholders from the sector and government. It is important that these stakeholders are involved in this process and work in a joint approach to increase the chance to create impact. It can be expected that this process will be organised in most countries and chains at some point. Such an approach will require substantial resources and will take time (a number of years). A complicating factor in defining a sectoral target is setting a fair share in emission reduction, as long as there is no specific methodology available.

More detailed recommendations related to target setting can be found in Chapter 2.3. 
This report is limited to target setting itself, to the approach that can be used to set targets and to the targets that have been set in the 4 case countries. For the initiative of the banking sector the following question has to be answered in a next step: How can sectoral pathways be developed either based on targets that have been set e.g. in national programmes or on sectoral climate scenarios similar to what has been done in the energy sector? The International Energy Agency has developed sustainable development scenario towards achieving net-zero emissions by $2050 .{ }^{1}$ Such a global sectoral scenario is not yet available for the dairy sector, but will be developed in 2021 by several organisations involved in the livestock sector. ${ }^{2}$

\subsection{Monitoring emissions of farms}

The goal of monitoring GHG emissions is to assess the baseline in order to (1) asses where the sector stands relative to a pathway/targets at country and/or sector level and to (2) suggest opportunities for reduction through available mitigation options. Monitoring can be organised in different ways. It is possible to work with (sector) models, samples or averages for specific types of farming/country combinations. This can help to list generic mitigation options and can also be used to estimate the emissions of the overall population,

In some countries and chains individual farm level GHG tools are widely used or will be widely adopted in the near future. The individual carbon footprint tools can contribute to raising awareness of farmers. With the right set up of the tool it can give the farmer insight into how different sources contribute to the overall GHG emission of the farm, it can provide a benchmark to compare his performance with peers and suggest specific mitigation options. These individual farm level tools can be used to monitor progress on targets on individual farms but also to set up monitoring of GHG emission on sector or portfolio level. For less professional farming systems (e.g. smallholders and subsistence farms) an individual carbon footprint is less relevant. For these type of farms the focus can be on getting the basics right and professionalising.

Overall many different tools are available which differ in scope $(1,2$ or 3$)$, in inclusion of other environmental themes, in methodology (e.g. inclusion of sequestration, (indirect) land use change), in resolution/precision (mitigation options), in verification, in connection to (digitally) available data and/or administrative burden and complexity and last but not least in outreach in use by farmers. In several countries tools are available, but not widely used. So, a first step that can be made is to increase the outreach. More details on the available tools in New Zealand, Netherlands, Australia and USA can be found in Chapter 3. Also some international tools are available. The Cool Farm Tool (CFT) can be used for many different farm types and is used in many countries and projects. The Cool Farm Tool is developed and maintained by an industry platform: the cool farm alliance. ${ }^{3}$ GLEAM and EX-ACT have been developed by FAO. These tools have not been developed primarily to be used by individual farmers, although this is possible. The main goal is to estimate impact for groups of farmers for assessing (potential) impacts of projects. GLEAM has been developed to be used on a broader level (e.g. regional or national level), but it is suitable for calculations at farm level as well. So if no other tools are available these tools could be used as a starting point. Ex-ACT is a simulation tool on project basis and not suitable for farm level calculations.

Overall GHG tools for dairy farmers are available in the countries studied and it is expected that the use will increase significantly driven by processing company targets. GHG monitoring should ideally be connected to existing databases, farm management systems or accountancy data to achieve a lower administrative burden for farms and improve the quality and consistency of the data. The availability of existing data is also a reason why many countries develop their own specific tool based on the available data. Another reason for national tools is that the tool can be modelled specifically for the national circumstances and farming systems.

\footnotetext{
1 https://www.iea.org/reports/world-energy-model/sustainable-development-scenario

2 http://www. livestockdialogue.org/

3 https://coolfarmtool.org/cool-farm-alliance/
} 
The financial sector is advised to align with the national tools when they are available and widely used or are expected to be widely used in the near future. This offers a great possibility to raise awareness and to organise (joint) incentives. The use of multiple tools on one farm should however be avoided to avoid confusion and administrative burden. Obviously minimum requirements for the use of tools have to be set. Results from national tools will at some point have to be harmonised for global portfolio results. If there are no national tools available, the alternative is to support the implementation of internationally harmonised tools.

If tools or data are not available and it is not expected that even with support of the financial sector, the use will increase in the short term, other proxies should be used to estimate the emissions of individual farmers as well as the bank portfolio in the short term. This can be done by using sector level models (GLEAM, EX-ACT) and estimating averages of penetration rates of mitigation options. Or by working with samples of farms either by asking clients to use a farm level tool or to extract information from existing samples like national Farm Accountancy Data Networks. This could be solved by developing emission profiles of typical dairy farms in these countries (e.g. extensive, intensive, herd size/composition, feedlot/pasture based, organic, et cetera). This approach requires a custommade solution per region based on data availability. This approach is less detailed then having farmspecific emission profiles. Also it is not possible to provide specific advice how the farmers could reduce their GHG emissions.

\subsection{Mitigation options}

Related to greenhouse gas emissions the dairy sector (and more in general agriculture) is more complicated than many other sectors. This also holds for mitigation options. For dairy 5 main categories of mitigation options can be distinguished:

- Animal production

- Animal management

- Feed production

- Manure management

- Production management.

For each category several mitigation options are available. Chapter 4 gives an overview of the main mitigation options, their GHG reduction potential and their requirements (skills, investment, time). The applicability of each mitigation option depends on farm type and farmer attitude.

This study has focused on 4 case studies in developed countries. The situation in many developing countries is very different. Smallholder farms with 1-5 cows are very common in those countries. These farms can in general be characterised as low efficiency farms with relatively high GHG emissions per kg of milk (Gerber et al., 2013).

\subsection{Overall conclusions}

\section{Overall conclusions}

Target-setting: The different steps for target setting are described in this report. The recommendation to the financial sector is where possible to align with national or sectoral targets that have been set. This is more efficient and working together with other stakeholders is a prerequisite to create impact.

Estimating current emission: The financial sector is advised to align with existing tools and programmes when they are available and widely used or are expected to be widely used in the near future. This offers a great possibility to raise awareness and to organise (joint) incentives. If there are no (national) tools available, the alternative is to work with samples of farms either by asking clients to use a farm level tool or to extract information from existing samples like national Farm Accountancy Data Networks for monitoring purposes. 
Mitigation options: Related to greenhouse gas emissions the dairy sector (and more in general agriculture) is more complicated than many other sectors. Chapter 4 gives an overview of a large number of mitigation options, their GHG reduction potential and their requirements (skills, investment, time). The applicability of each mitigation option depends on farm type and farmer attitude.

In an ideal situation goal setting, monitoring and mitigations options are all fully integrated and aligned with the Paris Agreement. This means that the methodology used for monitoring is fully aligned with the way the goal is defined and the effect of all mitigation options that have been identified are integrated in the monitoring tool. The current situation is however that some countries already have targets and tools in place as in all of the four case studies. The alignment with the relevant stakeholders is critical to achieve impact. Therefore, we propose to work with a growth model. Align with the tools that already are in use and with the goals that already have been set where this is the case. Specifically for the dairy sector it is relevant to note that the sector is working on a pathway to low carbon dairy, which will be available in 2021. 


\section{$1 \quad$ Samenvatting en synthese}

\subsection{Doel en werkwijze van het project}

Klimaatverandering en de vermindering van broeikasgasemissies vormen een van de belangrijkste uitdagingen voor bedrijven in de agrarische ketens. Deze ketens leveren een belangrijke bijdrage aan de wereldwijde totale broeikasgasemissie, maar ze kunnen ook een belangrijke rol spelen bij vermindering van de emissies. In de meeste agrarische ketens vindt een groot deel van de uitstoot plaats bij de primaire agrarische bedrijven, maar dit wil niet zeggen dat de boeren het probleem alleen moeten oplossen. De financiële sector kan en wil een belangrijke rol spelen om bij te dragen aan de oplossing van dit probleem. Rabobank werkt aan een initiatief waarin banken en financiële instellingen samenwerken om dit te voor elkaar te krijgen.

Als eerste stap heeft Rabobank een haalbaarheidsonderzoek laten uitvoeren om de mogelijkheden en knelpunten te beoordelen voor wat wordt gezien als drie basiselementen van een gezamenlijke aanpak voor de financiële sector:

- methoden om doelstellingen voor reductie van broeikasgasemissies vast te stellen en een traject om die doelstellingen te behalen, voor verschillende agrarische sectoren;

- een schatting van de huidige niveau van emissies, zowel op cliëntniveau (te beginnen bij primaire agrarische bedrijven) als op portefeuilleniveau, om de vooruitgang te kunnen monitoren; en

- identificatie van maatregelen voor vermindering van broeikasgasemissies, te gebruiken om boeren en andere partijen in de sector te kunnen ondersteunen.

Het gaat om een onderzoek van beperkte omvang. Het onderzoek wordt uitgevoerd voor de zuivelsector en er zijn vier landen (Nederland, Nieuw-Zeeland, Australië en de VS) geselecteerd voor een pilot. Het algemene doel is input verzamelen voor een manier waarop de financiële sector de wereldwijde broeikasgasemissies in landbouwsectoren kan monitoren en helpen verminderen. De drie genoemde elementen zijn los van elkaar onderzocht door middel van literatuuronderzoek, met aanvullend beperkte aandacht voor een algemene synthese. Het onderzoek, dat is uitgevoerd door Wageningen University \& Research en Blonk Consultants, liep van juli tot en met december 2020.

\subsection{Zuivelsector en broeikasgasemissies}

Op het gebied van broeikasgasemissies zijn specifiek de zuivelsector en de agrarische sector in het algemeen anders en ingewikkelder dan veel andere sectoren (hoofdstuk 2.1). Ten eerste is de zuivelproductie (net als de agrarische sector in het algemeen) gebaseerd op biologische processen, waarvan sommige onvermijdelijk tot emissies leiden, zoals de methaanemissie van herkauwers. Deze biologische processen zijn ook moeilijk volledig onder controle te houden, omdat ze afhankelijk kunnen zijn van bijv. de weersomstandigheden. Ten tweede is het emissieprofiel van melkveebedrijven complex. Een relevant deel van de uitstoot vindt upstream plaats (bijvoorbeeld bij inputs als veevoer en kunstmest) en de emissie is verdeeld over drie broeikasgassen: $\mathrm{CH}_{4}, \mathrm{CO}_{2}$ en $\mathrm{N}_{2} \mathrm{O}$. Er bestaan heel veel mogelijke maatregelen voor emissiereductie op melkveebedrijven, maar elke maatregel draagt afzonderlijk relatief weinig bij aan de totale vermindering (hoofdstuk 4). Bovendien hangt het uiteindelijke effect van de maatregelen af van veel variabele biologische factoren. Het complexere broeikasgasprofiel houdt ook in dat er tamelijk gedetailleerde gegevens nodig zijn om de broeikasgasuitstoot op bedrijfsniveau vast te stellen, vooral als het doel is om bedrijfsspecifiek advies te geven over passende emissie reducerende maatregelen. Beschikbaarheid en ontsluiting van gegevens voor monitoring van broeikasgasuitstoot op bedrijfsniveau zijn vaak lastig (hoofdstuk 3). Ten derde is het belangrijk te beseffen dat klimaatverandering niet het enige duurzaamheidsthema is in de zuivelsector, ook watergebruik en -kwaliteit, biodiversiteit en 
dierenwelzijn spelen een rol. Het is dus belangrijk om afwenteling te vermijden en te zorgen voor een integrale aanpak naar de melkveehouders (hoofdstuk 4).

Dit betekent niet dat er in de zuivelsector geen vooruitgang kan worden geboekt bij de vermindering van de uitstoot van broeikasgassen. Integendeel: er zijn allerlei klimaatmaatregelen beschikbaar en diverse onderzoeken laten zien dat de uitstoot kan worden verminderd (hoofdstuk 4). Uit veel programma's in de zuivelsector is gebleken dat er vooruitgang kan worden geboekt op specifieke gebieden door een goed plan met de juiste stimulansen en afstemming met de relevante stakeholders (Reijs et al, 2021).

\subsection{Doelstelling}

De volgende stappen of keuzes zijn nodig om een doelstelling te definiëren (hoofdstuk 2.2):

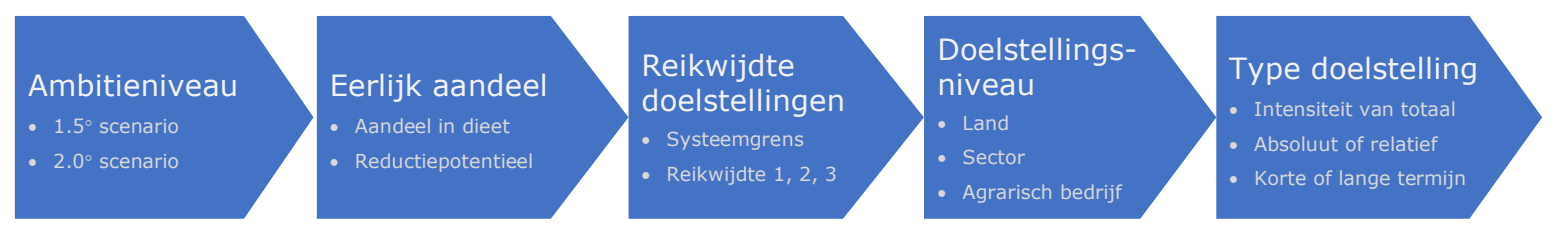

Er bestaat een algemene aanpak voor het vaststellen van wetenschappelijk onderbouwde doelstellingen, die ook relevant is voor de land- en bosbouw. Een belangrijke belemmering voor de rapportage over landbouw, bosbouw en landgebruik is het gebrek aan beschikbare standaarden. Het Science Based Target-initiatief werkt hieraan in het kader van het SBTi FLAG-project. Het is belangrijk om veranderingen in landgebruik en koolstofvastlegging mee te nemen, want die zijn relevant voor de broeikasgasberekeningen in de zuivelsector, net als in de meeste andere landbouwsectoren.

In Nederland en Nieuw-Zeeland zijn er nationale broeikasgasdoelstellingen (overeenkomst tussen overheid en sector) vastgesteld voor de gehele veehouderijsector. In Australië en de VS zijn er doelstellingen vanuit de zuivelsector zelf. Sommige individuele zuivelbedrijven hebben eigen doelstellingen vastgesteld. Een complicerende factor is het verschil in reikwijdte tussen de verschillende doelstellingen. Zuivelbedrijven en soms ook de zuivelsector werken vaak met een 'cradle to factory'-reikwijdte (LCA-productvoetafdruk) en nationale doelstellingen zijn gekoppeld aan de nationale emissieregistraties, die gebaseerd zijn de IPCC-emissiesectoren. Bij de IPCC-emissiesector landbouw gaat het alleen om de uitstoot van overige broeikasgassen (anders dan $\mathrm{CO}_{2}$ ) afkomstig van pensfermentatie, gebruik van mest en directe en indirecte $\mathrm{N}_{2} \mathrm{O}$-uitstoot uit de bodem. Het is belangrijk om deze verschillen in het oog te houden en er rekening mee te houden in de algemene benadering.

Het is niet zo eenvoudig om na te gaan of de sectordoelstellingen in overeenstemming zijn met het klimaatakkoord van Parijs, omdat nationale plannen meestal niet per sector worden gemaakt en er alleen wordt beoordeeld of het nationale programma voldoet aan de doelen van het klimaatakkoord. De tweede complicerende factor is dat bij het klimaatakkoord het idee is dat de vooruitgang om de vijf jaar wordt beoordeeld ('stock take') op basis waarvan landen een bijgewerkte nationaal vastgestelde bijdrage moeten leveren met een ambitieuzere reductiedoelstelling.

In principe zijn er twee scenario's mogelijk als de financiële sector wil werken met doelstellingen:

1. $\mathrm{Er}$ is al een regionale of nationale sectordoelstelling beschikbaar.

Als er een nationale of sectordoelstelling is, dan krijgt de financiële sector vanuit dit onderzoek het advies om zijn werk daarop af te stemmen. Het belangrijkste voordeel is dat er direct actie kan worden ondernomen. Bij de onderzochte landen in deze studie zijn reeds specifieke doelstellingen voor de zuivelsector vastgesteld. Nadelen zijn dat verschillende regio's verschillende doelstellingen hebben en dat het onzeker is of elke regionale sectordoelstelling in overeenstemming is met het klimaatakkoord van Parijs. Een mogelijke vervolgactie kan zijn op vast te stellen of het doel 
passend is en indien dit niet het geval is het gesprek aan te gaan met de stakeholders in de regio over het bijstellen van de doelstelling.

2. Er is geen regionale of nationale sectordoelstelling.

Als er geen regionale of nationale sectordoelstelling is, krijgt de financiële sector vanuit dit onderzoek het advies om te beginnen met prioritering van relevante sectoren en regio's, op basis van de mogelijke impact (wat betreft uitstootniveau en reductiepotentieel). Hierna volgt bij voorkeur de stap om doelstellingen te ontwikkelen in samenspraak met relevante stakeholders uit de sector en de overheid. Het is belangrijk dat die stakeholders bij dit proces worden betrokken en werken volgens een gezamenlijke aanpak, zodat de kans op het creëren van impact groter wordt. Er mag verwacht worden dat dit proces in de meeste landen en ketens op een bepaald moment zal worden georganiseerd. Voor zo'n aanpak is een aanzienlijke hoeveelheid middelen en tijd nodig (een aantal jaren). Een complicerende factor bij het vaststellen van een sectordoelstelling is het bepalen van een eerlijk aandeel in de uitstootreductie voor de betreffende sector, zolang er geen specifieke methode beschikbaar is.

Gedetailleerde aanbevelingen voor het vaststellen van doelstellingen zijn te vinden in hoofdstuk 2.3.

Dit verslag beperkt zich tot het vaststellen van doelstellingen zelf, de aanpak die kan worden gebruikt om doelstellingen vast te stellen, en de doelstellingen uit de vier casestudylanden. Voor het initiatief van de bankensector moet in een volgende stap de volgende vraag worden beantwoord: hoe kunnen er routes of scenario's worden ontwikkeld op basis van doelstellingen die bijvoorbeeld in nationale programma's zijn vastgesteld of op basis van klimaatscenario's per sector, naar het voorbeeld van de energiesector? Het Internationaal Energieagentschap heeft een duurzaam ontwikkelingsscenario opgezet om in 2050 een uitstoot van net-zero te bereiken. ${ }^{4}$ Zo'n wereldwijd sectorscenario is nog niet beschikbaar voor de zuivelsector, maar zal in 2021 worden ontwikkeld vanuit verschillende organisaties die bij de veehouderij betrokken zijn. ${ }^{5}$

\subsection{Uitstootmonitoring van agrarische bedrijven}

De monitoring van broeikasgasuitstoot heeft als doel de uitgangssituatie te evalueren om (1) te beoordelen waar de sector staat ten opzichte van een doelstellingen op nationaal en/of sectorniveau en (2) mogelijkheden voor reductie voor te stellen via beschikbare maatregelen. Monitoring kan op verschillende manieren worden georganiseerd. Er kan worden gewerkt met (sector)modellen, steekproeven of gemiddelden voor specifieke bedrijfstype-landcombinaties. Dat kan helpen bij het opstellen van een lijst van generieke klimaatmaatregelen (welke maatregelen zijn relevant voor deze regio) en kan ook worden gebruikt om de uitstoot van de gehele populatie te schatten.

In sommige landen en ketens worden tools om de broeikasgasemissies op bedrijfsniveau te bereken nu of binnen afzienbare tijd op grote schaal gebruikt. De individuele berekening van de individuele voetafdruk kan een bijdrage leveren aan het creëren van bewustzijn bij boeren. Als de tool goed is ontworpen dan is het een goed hulpmiddel voor de boer om inzicht te krijgen in de bijdrage van de verschillende bronnen aan de totale broeikasgasuitstoot van het bedrijf. Ook biedt de tool de mogelijkheid om tot een benchmark te komen, om de prestaties van de boer te vergelijken met die van collega's en kunnen eventueel specifieke reductiemogelijkheden worden voorgesteld. Deze tools op het niveau van individuele agrarische bedrijven kunnen worden gebruikt om de voortgang van de doelstellingen op individuele agrarische bedrijven te monitoren, maar ook als basis dienen voor het monitoren van de broeikasgasuitstoot op sector- of portefeuilleniveau. Voor minder productieve landbouwsystemen (bijvoorbeeld kleine boerenbedrijven en zelfvoorzienende landbouw) is een individuele voetafdruk minder relevant. Bij dit soort bedrijven kan de nadruk liggen op het verbeteren van het vakmanschap en de productiviteit door nadruk te leggen op de basis van het melkveebedrijf.

In het algemeen zijn er allerlei tools beschikbaar, die verschillen wat betreft reikwijdte (scope 1, 2 of 3), opname van andere milieuthema's, in methode (bijvoorbeeld opname van koolstofvastlegging,

\footnotetext{
4 https://www.iea.org/reports/world-energy-model/sustainable-development-scenario

5 http://www.livestockdialogue.org/
} 
(indirecte) veranderingen in landgebruik), resolutie/nauwkeurigheid (klimaatmaatregelen), verificatie, aansluiting op (digitaal) beschikbare gegevens en/of administratieve lasten en complexiteit en - last but not least - in hoeverre boeren ze gebruiken. In verschillende landen zijn tools beschikbaar die niet op grote schaal worden gebruikt. Een eerste stap die kan worden gezet is dus het vergroten van het bereik. Meer informatie over de beschikbare tools in Nederland, Nieuw-Zeeland, Australië en de VS is te vinden in hoofdstuk 3. Er zijn ook enkele internationale tools beschikbaar. De Cool Farm Tool (CFT) kan worden gebruikt voor veel verschillende soorten agrarische bedrijven en wordt in veel landen en projecten ingezet. Deze tool is ontwikkeld en wordt onderhouden door een platform met vertegenwoordigers uit de sector, de Cool Farm Alliance. ${ }^{6}$ GLEAM en EX-ACT zijn ontwikkeld door de FAO. Deze tools zijn niet in de eerste plaats ontwikkeld voor individuele boeren, alhoewel die ze wel kunnen gebruiken. Het hoofddoel is de impact voor groepen boeren te schatten om de (mogelijke) effecten van projecten te beoordelen. GLEAM is ontwikkeld voor gebruik op een breder niveau (bijv. regionaal of nationaal), maar is ook geschikt voor berekeningen op bedrijfsniveau. Als er geen andere tools beschikbaar zijn, kunnen deze tools dus worden ingezet om in ieder geval een begin te kunnen maken. Ex-ACT is een simulatietool op projectbasis en is niet geschikt voor berekeningen op bedrijfsniveau.

In de onderzochte landen zijn broeikasgastools voor melkveehouders beschikbaar en er wordt verwacht dat het gebruik daarvan aanzienlijk zal toenemen als gevolg van de klimaatdoelstellingen van de verwerkende bedrijven. De monitoring van broeikasgassen wordt in het ideale geval gekoppeld aan bestaande databanken of managementsystemen van agrarische bedrijven of boekhoudkundige gegevens om de administratieve lasten voor boeren te verminderen en de kwaliteit en de consistentie van de gegevens te verbeteren. De beschikbaarheid van bestaande gegevens vormen ook een reden waarom veel landen hun eigen specifieke tool ontwikkelen. Een andere reden voor nationale tools is dat de tool specifiek kan worden gemodelleerd voor de omstandigheden en bedrijfssystemen in het land.

De financiële sector krijgt het advies om zich aan te sluiten bij de nationale tools als die er zijn en breed worden toegepast, of als dat naar verwachting binnen afzienbare tijd het geval zal zijn. Dit biedt een goede mogelijkheid om het bewustzijn te vergroten en (gezamenlijke) stimuleringsmaatregelen te organiseren. Gebruik van meerdere tools voor één agrarisch bedrijf moet worden vermeden om verwarring en administratieve rompslomp te voorkomen. Vanzelfsprekend moeten er minimumeisen worden gesteld aan de te gebruiken tools. De resultaten van de nationale tools zullen moeten worden geharmoniseerd om tot wereldwijde portefeuilleresultaten te kunnen komen. Als er geen nationale tools beschikbaar zijn, dan is het alternatief om de toepassing van internationaal geharmoniseerde tools te ondersteunen.

Als er geen tools of gegevens zijn en als niet te verwachten is dat het gebruik op korte termijn zal toenemen - zelfs niet met steun van de financiële sector -, dan moeten andere manieren worden gebruikt om de uitstoot van individuele boeren en van de bankportefeuille te schatten. Dit kan met modellen op sectorniveau (GLEAM, EX-ACT) en schattingen van gemiddelde adoptie van klimaatmaatregelen. Ook kan er worden gewerkt met steekproeven van agrarische bedrijven, door cliënten te vragen een bedrijfstool te gebruiken, of door informatie uit bestaande steekproeven te halen, zoals de nationale netwerken voor informatie over agrarische bedrijfsboekhoudingen (bijvoorbeeld EU FADN). Een andere manier is om emissieprofielen op te stellen van typische melkveebedrijven in deze landen (bijvoorbeeld extensief, intensief, omvang/samenstelling van de veestapel, met weidegang, biologisch, enzovoort). Voor een dergelijke aanpak is een op maat gemaakte oplossing per regio nodig op basis van de beschikbare gegevens. Deze aanpak is minder gedetailleerd dan het opstellen van bedrijfsspecifieke uitstootprofielen. Ook kan er geen bedrijfsspecifiek advies worden gegeven over hoe de boeren hun broeikasgasuitstoot kunnen verminderen.

$\overline{6_{\text {https://coolfarmtool.org/cool-farm-alliance/ }}}$ 


\subsection{Klimaatmaatregelen}

Wat broeikasgasuitstoot betreft, is de zuivelsector (en meer in het algemeen de landbouw) ingewikkelder dan veel andere sectoren. Dat geldt ook voor de klimaatmaatregelen. Voor zuivel zijn er vijf maatregel-categorieën te onderscheiden:

- Dierlijke productie

- Dierbeheer

- Voederproductie

- Beheer organische mest

- Productiebeheer.

Voor elke categorie bestaan er verschillende maatregelen. Hoofdstuk 4 bevat een overzicht van de belangrijkste klimaatmaatregelen, in hoeverre de broeikasgasuitstoot hiermee kan worden verminderd, en wat ervoor nodig is (vaardigheden, investeringen, tijd). De toepasbaarheid van elke maatregel hangt af van het type agrarisch bedrijf en de houding en voorkeur van de boer.

Bij dit onderzoek is er gekeken naar vier casestudy's in ontwikkelde landen. De situatie in veel ontwikkelingslanden is heel anders. Kleine agrarische bedrijven met 1-5 koeien komen veel voor in die landen. Deze bedrijven zijn over het algemeen weinig efficiënt met een relatief hoge broeikasgasuitstoot per kg melk (Gerber et al., 2013).

\subsection{Algemene conclusies}

\section{Algemene conclusies}

Doelstellingen vaststellen: De verschillende stappen voor het vaststellen van doelstellingen worden in dit verslag beschreven. De financiële sector krijgt het advies om waar mogelijk aan te sluiten bij gestelde nationale of sectordoelstellingen. Dit is efficiënter en samenwerking met andere stakeholders is een eerste vereiste om impact te creëren.

Schatting van de huidige uitstoot: De financiële sector krijgt het advies om zich aan te sluiten bij bestaande tools en programma's als die er zijn en breed worden toegepast, of als dat naar verwachting binnen afzienbare tijd het geval zal zijn. Dit biedt een goede mogelijkheid om het bewustzijn te vergroten en (gezamenlijke) stimuleringsmaatregelen te organiseren. Als er geen (nationale) tools beschikbaar zijn, is het alternatief om te werken met steekproeven van agrarische bedrijven. Dat kan door cliënten te vragen een bedrijfstool te gebruiken, of door informatie voor monitoring uit bestaande steekproeven te halen, zoals de nationale netwerken voor informatie over agrarische bedrijfsboekhoudingen.

Klimaatmaatregelen: Wat broeikasgasuitstoot betreft, is de zuivelsector (en meer in het algemeen de landbouw) ingewikkelder dan veel andere sectoren. Hoofdstuk 4 bevat een overzicht van een grote hoeveelheid maatregelen, in hoeverre de broeikasgasuitstoot hiermee kan worden verminderd, en wat ervoor nodig is (vaardigheden, investeringen, tijd). De toepasbaarheid van elke maatregel hangt af van het type agrarisch bedrijf en de houding van de boer.

In een ideale situatie zijn doelstellingen, monitoring en klimaatmaatregelen volledig geïntegreerd en afgestemd op het klimaatakkoord van Parijs. Dit betekent dat de monitoringmethode volledig is afgestemd op de manier waarop het doel is gedefinieerd en dat het effect van alle geïdentificeerde maatregel in de monitoringtool is geïntegreerd. In de huidige situatie beschikken sommige landen echter al over doelstellingen en tools, zoals het geval is in alle vier de casestudy's. Om impact te realiseren, is afstemming met de relevante stakeholders essentieel. Daarom is ons voorstel om te werken met een groeimodel. Zorg voor afstemming met bestaande tools en doelstellingen, voor zover van toepassing. Specifiek voor de zuivelsector is het relevant op te merken dat de sector werkt aan een traject naar zuivel met weinig broeikasgasemissies, die in 2021 beschikbaar zal zijn. 


\section{$2 \quad$ Target setting}

\subsection{Introduction}

One of the questions for this study was to develop a methodology for setting up GHG emission targets for different agro-sectors. The content of this chapter is based on literature review.

The introduction part of this chapter (2.1) describes (1) the climate policy context, (2) some specific elements from agriculture, (3) targets in place for the case of this study (dairy in 4 countries) and the general approach of science based targets setting as methodology. The second part of this chapter elaborates on the approach of target setting step by step and addresses the choices that have to be made for each step. This chapter will not provide the targets itself, as these involve choices that are rather societal / political choices than scientifically based decisions.

\subsubsection{Policy context}

Climate change is the major challenge for humanity in the 21th century and to overcome it, reduction of greenhouse gas (GHG) emissions is essential. On December $21^{\text {st }} 2015$ and for the first time all nations reached an important agreement to tackle the climate change problems, accelerate the actions and investments, and to support developing countries to do so. The central aim of Paris agreement was setting a global framework to avoid the threats of climate change by keeping the global average temperature rise below 2 degrees Celsius and pursuing efforts to limit it even further to 1.5 degree Celsius. To achieve these ambitious goals, an appropriate mobilisation and provision of financial resources, a new technology framework and enhanced capacity-building need to be considered. This takes place through 'nationally determined contributions' (NDCs) in which each country should express their national mitigation target. Therefore, countries have been committed to determine, plan and report regularly their emissions and implement effort to mitigate the global warming.

In this regard, the member states of the EU have committed themselves to reduce the GHG emissions by at least $40 \%$ (1990 baseline) by 2030, and the European Commission recently proposed to increase the ambition to $55 \%$ reduction. The longer term ambitious goal for the EU is to be climateneutral by 2050 . This climate action is at the heart of the European Green Deal which is an ambitious package of measures ranging from ambitiously cutting greenhouse gas emissions, to investing in cutting-edge research and innovation, to preserving Europe's natural environment (EC, 2020). The Netherlands as an EU member aims to raise the EU ambition from $40 \%$ to $55 \%$ emission reduction by 2030. The current target of the Dutch Climate agreement is a reduction of $49 \%$ of greenhouse gas emissions in 2030 compared with 1990. The United States intends to reduce its GHG emissions by 26$28 \%$ (2005 baseline) by 2025. Australia aims at 26-28\% GHG emissions reduction below 2005 levels by 2030 . New Zealand committed to reduce GHG emissions to $30 \%$ below 2005 by 2030 and also set a new ambitious national target to reduce the emissions to net zero by 2050 . To achieve the net-zero carbon target, in the first step the human induced emissions should be reduced as close to zero by applying mitigation strategies. Afterwards the remaining human-induced emissions should be removed from the atmosphere by applying carbon removal technologies or processes (e.g. afforestation or air capture and storage technologies). However, most of the national targets are not yet made sector specific, which makes it complicated to translate these overall targets to individual targets at sector, company or farm level. Moreover, not all National Determined Contributions (NDCs) or national targets are yet Paris compliant. Alignment for overall national targets can be checked (for some countries) at https://climateactiontracker.org/. Almost no country is currently on track to reach the goals of the Paris Agreement and should increase their ambition. This is also part of the Paris Agreement, which includes a five yearly stock take where countries should provide an updated National Determined Contribution (NDC) with an more ambitious reduction target. This first stock take was in 2020, when countries had to provide their NDC by December 2020. At this stock take the EU increased its ambition from $40 \%$ reduction to $55 \%$ reduction by 2030 . 
Agriculture, Forestry and Other Land Use (AFOLU) sector emits nearly a quarter of the global humaninduced GHG emissions (Smith et al., 2014). GHG emission reductions in the AFOLU sector are therefore critical for meeting the global climate targets (Wollenberg et al., 2016). However, most of the GHG emissions from agriculture are methane $\left(\mathrm{CH}_{4}\right)$ and nitrous oxide $\left(\mathrm{N}_{2} \mathrm{O}\right)$, which are formed by biological processes. These emissions are much more complicated to control compared to energy related emissions, and there is recognition that these emissions cannot be reduced to zero.

\subsubsection{What makes the agricultural sector different?}

The agricultural sector, in this case dairy, differs from many other sectors when it comes to greenhouse gas emissions.

First, the production of dairy (and agriculture in general) is based on biological processes, some of which inevitably lead to emissions, like the methane emission of ruminants. These biological processes are also complicated to control in detail because they can depend on e.g. weather circumstances. So it is not a production system in a strictly controlled environment.

The emission profile of dairy farms is complex. A relevant share of the emissions is upstream (e.g. in inputs as feed and fertiliser) and the emissions are divided over $\mathrm{CH}_{4}, \mathrm{CO}_{2}$ and $\mathrm{N}_{2} \mathrm{O}$. Many other sectors only, or at least mainly, relate to $\mathrm{CO}_{2}$ emissions and the use of fossil energy. For the dairy sector there is a large number of mitigation options, but each option contributes relatively little to the overall reduction (see also Chapter 4 ). Moreover the impact of a single mitigation option depends on and is influenced by many (variable biological) factors.

For other sectors the use of energy is often a main factor in GHG emissions, so one of the key mitigation options for these sectors is switching to the use of renewable energy. The direct use of energy contributes only about 3-4\% of the total GHG emission on dairy farmers (cradle-to-farm gate, Doornewaard 2020). This more complex emission profile also implicates that quite some data is required to make an accurate assessment of GHG emission on farm level. E.g. feed ration composition has a major influence on the methane emission of ruminants (see also Chapters 3 and 4).

Another complicating factor is the large number of dairy farms and the very heterogeneous population. In the studied case countries, the number of farms varies from about 6,000 in Australia to about 34,000 in the USA, almost each with its own independent owner. Even within these countries the farming systems vary greatly: from grassland-based systems with very limited external inputs like concentrates to footloose systems with very high external inputs based on corn, alfalfa and concentrates. If we also include developing countries the numbers and heterogeneity increases even further. In a country like India it is estimated that there are about 12 million farmers, most of them only keeping a small number of cows (1-5). This type of smallholder farms is quite common in many developing countries.

Finally, it is important to be aware of the fact that the dairy sector relates to more sustainability topics than climate change: e.g. water use and quality, biodiversity and animal welfare. So, it is important to be aware of trade-offs and ensure an integrated approach towards the dairy farmers

But all this does not mean it is not possible to achieve progress. On the contrary: many programmes in the dairy sector have shown that progress on specific topics can be achieved if a good plan with the right incentives and alignment with the relevant stakeholders is in place.

\subsubsection{Sector initiatives}

Beside countries, companies and private sectors have their own role in combatting the climate change. The transition to a low-carbon economy is underway and accelerating globally and companies play an important role in it. In the dairy sector several large companies have recently set targets for GHG reduction on the longer term. As an example, Danone set the target to reduce GHG intensity by $50 \%$ (2015 baseline) by 2030, including scope 3 , and the ambitious target is to become carbon neutral (net-zero) by 2050 . The climate target is not the only target that is in scope for Danone and other 
dairy companies. Danone has developed a holistic programme with three pillars including protecting soil, water and biodiversity, empowering a new generation of farmers and promoting animal welfare are considered. Another example is Arla Foods which has the main target to reduce greenhouse gas emissions by $30 \%$ per kilogram of milk over the next decade and to work towards carbon net zero by 2050. Also, the US Dairy sector has set a goal to become carbon neutral by 2050, which they believe is achievable based on today's science, technology and innovation. ${ }^{7}$ An overview of current targets related to the dairy sector, for the countries involved in the feasibility study, is provided in Table 2.1.

Table 2.1 Overview of GHG reduction targets related to the dairy sector for the four countries included in this feasibility study

\begin{tabular}{|c|c|c|c|}
\hline Country & Type & Target & Target year \\
\hline Netherlands & $\begin{array}{l}\text { National (Climate } \\
\text { agreement) a) }\end{array}$ & $\begin{array}{l}\text { - } 1.2-2.7 \text { Megatonnes } \mathrm{CO}_{2} \text { eq reduction for } \mathrm{CH}_{4} \text { from livestock } \\
\text { production } \\
\text { - } 1 \text { Megatonne } \mathrm{CO}_{2} \text { reduction for peat soils } \\
\text { - } 0.4-0.6 \text { Megatonne } \mathrm{CO}_{2} \text { sequestration in agricultural soils }\end{array}$ & 2030 \\
\hline New Zealand & National & $\begin{array}{l}\text { 24-47\% below } 2017 \text { biogenic methane emissions by 2050, } \\
\text { including 10\% below } 2017 \text { biogenic methane emissions by } 2030 \text {. }\end{array}$ & $2030 / 2050$ \\
\hline United States & Sector & Carbon neutral & 2050 \\
\hline
\end{tabular}

a) Only targets related to the dairy and/or livestock sector, targets are additional to current policy.

The US target for the dairy sector is Paris aligned. For the sectoral targets of other countries this has not been assessed accurately.

\subsubsection{Science based targets setting}

The Science Based Targets initiative $(\mathrm{SBTi})^{8}$ provides companies the pathway to a low carbon economy by specifying how much and how quickly they need to reduce their GHG emissions. The SBTi is a joint initiative by Carbon Disclosure Project (CDP), the United Nations Global Compact (UNGC), the World Resources Institute (WRI) and the World Wide Fund for Nature (WWF) intended to increase corporate ambition on climate action. This will occur by mobilising companies to set GHG mitigation targets consistent with the level that has been set by science to limit warming to less than $1.5^{\circ} \mathrm{C}$ or $2{ }^{\circ} \mathrm{C}$ compared to preindustrial temperatures. Based on the most recent SBTi report, 978 companies are taking science-based climate action and 460 companies have approved science-based targets.

AFOLU (Agriculture, Forestry and Other Land Use) as one of the contributors of global GHG emissions is not publicly reported in GHG emissions of many companies because they are limited by several factors such as lack of consistent methodology and standards. The SBTi Forest, Land and Agriculture project (SBTi FLAG) led by WWF is a sector developed project to fill this methodology gap. It helps the companies in food, agriculture and forest sector to set the science based targets. Results from the project are expected in the second quarter of 2021. Although the science based target initiative is very useful for many companies, it currently lacks a good methodology for the AFOLU sector and can therefore yet not be used for target setting for the dairy sector.

\subsubsection{Objective}

The objective of this part of the report is to provide an overview and approach on how to set GHG reduction targets for the dairy sector. This will be a stepwise approach, where each step requires certain choices that have to be made. This feasibility study will provide an overview and guidance related to these choices and the possible implications. The feasibility study will not provide the targets itself, as these involve choices that are rather societal/political choices than scientifically based decisions. These kind of choices have to be made by the financial sector, and other stakeholders in a joint follow up trajectory.

\footnotetext{
7 https://www. usdairy.com/sustainability/environmental-sustainability

8 https://sciencebasedtargets.org/
} 


\subsection{Approach for setting targets}

\subsubsection{Overall approach}

In this chapter we describe the approach on how to set GHG reduction targets for the dairy sector. The first step is to determine the overall ambition level, i.e. aim for a 1.5 degree scenario or 2.0 degree scenario. The second step is to determine what share of the GHG remaining emissions are allowed for the dairy sector (compared to other ag and non-ag sectors) and how these should be distributed between regions/countries in a fair way given prior progress made and further improvement potential and related costs. This step is strongly related to choices on future consumption patterns, which amongst other aspects determine the demand for dairy products. Next, the scope and system boundary for the emissions that are part of the target have to be set. In the following step the target is further specified to countries, sectors or possibly even individual farmers. Finally, choices have to be made on the type of target, an intensity target (in $\mathrm{kg} \mathrm{CO} 2 \mathrm{eq} / \mathrm{kg}$ milk) versus a total reduction target, an absolute emission reduction versus a relative emission reduction and a short term (e.g. 2025) versus long-term (2050) target. These steps are summarised in the figure below.

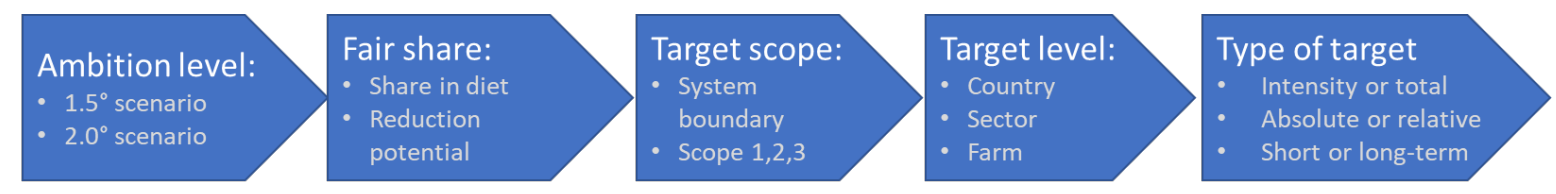

\subsubsection{Setting an overall reduction target}

According to the Intergovernmental Panel on Climate Change (IPCC) estimation to have a chance (with the probability of $50-66 \%$ ) of meeting the $2{ }^{\circ} \mathrm{C}$ target, the world GHG emissions need to be reduced to $400-450 \mathrm{ppm} \mathrm{CO}_{2}$ eq (Fisher et al., 2007). The question arises which one of the Paris Agreement targets (limiting warming to $1.5^{\circ} \mathrm{C}$ or $2^{\circ} \mathrm{C}$ target) should be considered? And does half a degree of warming make a big difference?

To understand the impact of a half degree increase, IPCC estimated the difference between the impacts of a $1.5^{\circ} \mathrm{C}$ temperature limit and $2^{\circ} \mathrm{C}$. According to the findings, half a degree increase in world temperature may cause millions of more people to be at risk of severe heat, sea level rise, water stress, poverty, and loss of global fisheries catch (see Table 2.2). Moreover, a degree increase in world temperature will create unpredictable situation for people and ecosystem. Therefore, it is critical to accelerate efforts to decrease the GHG emissions. 
Table 2.2 Differences between limiting global warming to $1.5^{\circ} \mathrm{C}$ and $2^{\circ} \mathrm{C}$

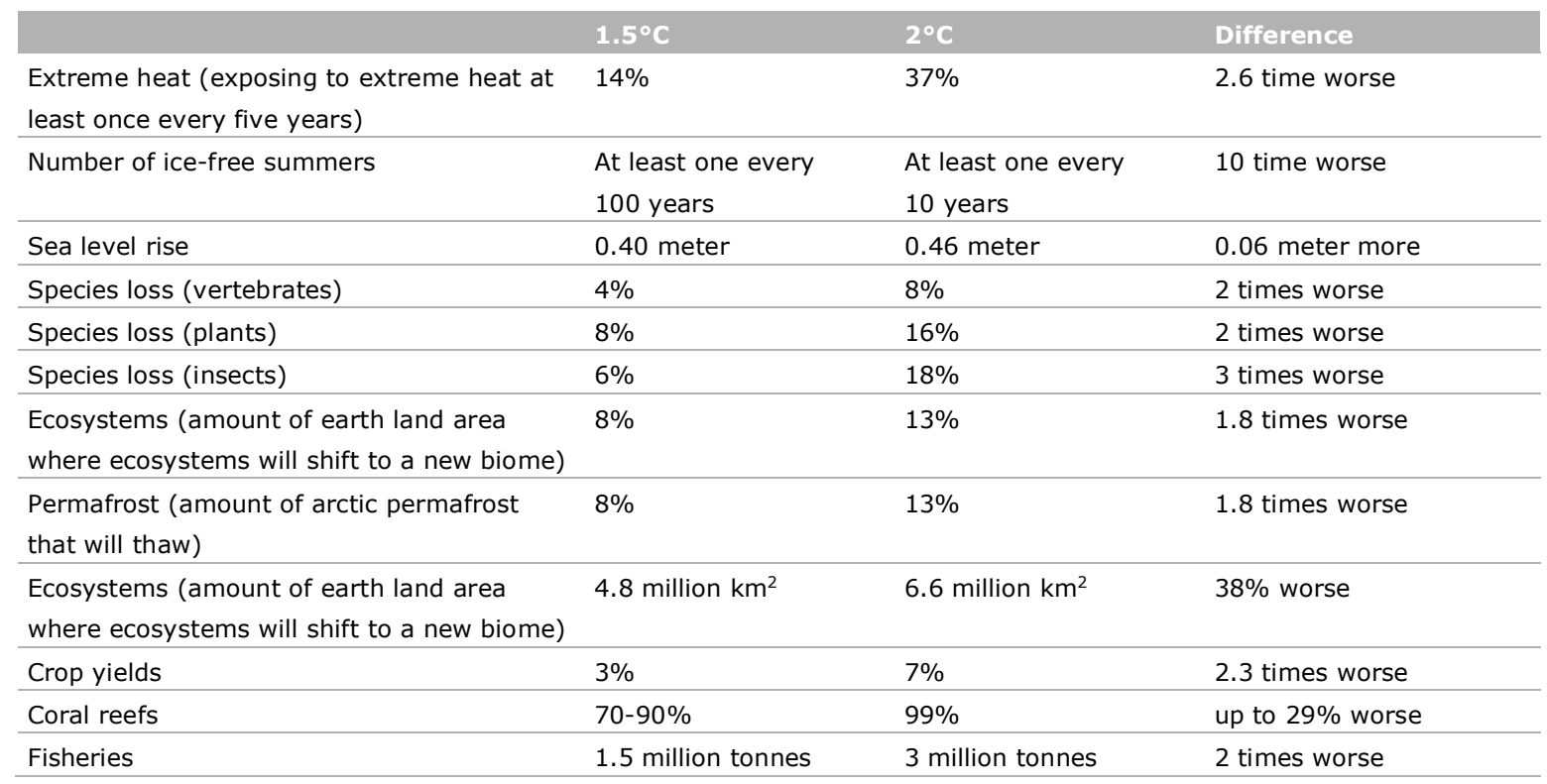

Source: Masson-Delmotte et al. (2018); WRI (2018).

Regarding the connection and dependency of environment, economy and society, efforts to mitigate GHG emissions in the agricultural sector (specifically the livestock sector) may lead to some socioeconomic problems. For example, efforts for GHG emissions reduction may negatively affect the food security. These socio-economic problems reduce the mitigation scenario impacts and performances. Therefore, all changes need to be implemented at the same time. The lower production of e.g. meat and dairy because of the implementation of mitigation options might be balanced by the implementation of strategies for defining the healthy and sustainable diet.

As a conclusion, the main scenario to limit global warming to $1.5^{\circ} \mathrm{C}$ by 2030 requires:

- GHG mitigation activities to reduce the emission of the agricultural products

- Changes in diet to meet the targets for healthy food and sustainable food production

- Negative emission efforts such as afforestation or other biological processes to capture carbon, bioenergy production and carbon capture technologies.

\subsubsection{Determining a fair share for the dairy sector}

\subsubsection{Approach}

After determining the overall GHG reduction ambition, a fair share of the remaining GHG emissions has to be determined for the dairy sector. The Paris Agreement and many scientific studies acknowledge that GHG emissions in agriculture cannot be reduced to zero. First, food production will have to continue to feed a growing population and, second, most emissions from this sector come from biological processes that can be only influenced to a limited extent. To determine the fair share in the remaining emissions the following questions have to be answered:

- What will be the future demand for dairy products?

- What is the technical mitigation potential for the dairy sector?

- To what extent can negative emissions be used to compensate for remaining emissions?

As global population grows, total demand for food products will increase as well. In most Western countries the consumption of animal products is high and can be reduced, also because of health reasons. However, in many developing countries the demand for animal products will increase, because of i) growing population; ii) nutritional reasons; and iii) economic development, which allows for spending more money on livestock products. Determining future diets will be complicated, since changing consumer behaviour is difficult to influence. This aspect therefore typically has to be addressed in scenario studies, which assess the impact of different diets and implementation of GHG 
mitigation options. In the following sections some relevant scenario studies are shortly described, including the EU long-term strategy and the EAT-Lancet diet study.

The second aspect determines to what extent the current GHG emissions can be reduced. A range of mitigation options is available, as described in Chapter 4. However, to what extent these options can be applied very much depends on the local circumstances. First, strategies differ depending on the current productivity level of the sector, where developing countries with low milk yields should go for sustainable intensification, whereas in high-productive countries more technical options are relevant. Also the physical circumstances, such as soils and climate, determine the type of dairy farming (e.g. grass based dairy farming) and relevant mitigation options and outcomes/impacts. And finally, national policies and availability of private incentives determine to what extent the farmer will actually implement these mitigation options. One could say a farmer needs a reason to change his way of farming. This reason can be knowledge or insights, it can also be better technical and financial results or it can be that the farmer is simply obliged to implement certain technology to reduce the emission. These incentives have to be organised. Several processors have sustainability programmes in places where they provide knowledge, tools and sometimes premiums (Reijs et al., 2021).

Also the last aspect on the amount of negative emissions is relevant for reaching climate neutrality, as not all emissions from agriculture can be avoided. In this case it is important to assess to what extent these negative emissions can be reached within the sector, e.g. sequestration of carbon in agricultural soils, or whether these are outside the sector, e.g. afforestation. Recently the SBTi presented a report (Carrillo Pineda et al., 2020), which proposes foundations for science-based net-zero target setting in the corporate sector.

The report includes an assessment of five hypothetical mitigation strategies:

1. Replacing value-chain emission reductions with carbon credits

2. Replacing abatement with avoided emissions from products and services

3. Replacing abatement with negative emissions

4. Emissions abatement in line with science

5. Climate positive approach

Table 2.3 presents a summarised assessment of the strategies. Only strategy 4 and 5 comply with the three principals that the emission reduction should be 1) consistent with no net accumulation of GHGs in the atmosphere, 2) consistent with the attainment of the Paris Agreement and SDGs, and 3) a resilient business model in a net zero economy. 
Table 2.3 Summarised assessment of 5 mitigation strategies

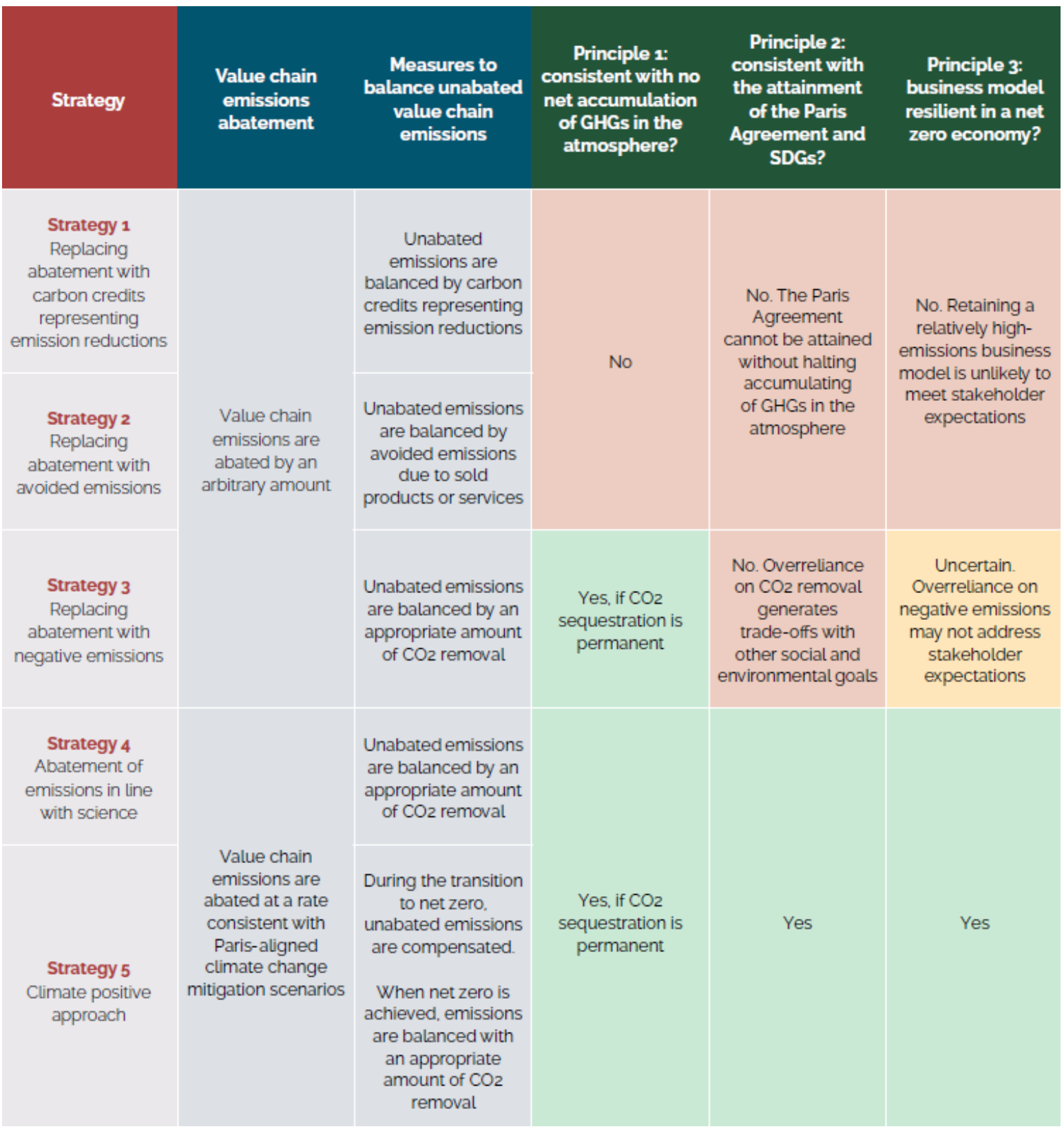

Source: Carrillo Pineda et al. (2020).

\subsubsection{Example studies}

\section{European Union 2050 long-term strategy}

The European Commission set out its vision for a climate-neutral EU in November 2018. The vision covers nearly all EU policies and is in line with the Paris Agreement objective to keep the global temperature increase to well below $2^{\circ} \mathrm{C}$ and pursue efforts to keep it to $1.5^{\circ} \mathrm{C}$. As part of the European Green Deal, the Commission proposed on 4 March 2020 the first European Climate Law to enshrine the 2050 climate-neutrality target into law. In the accompanying Impact Assessment, several 1.5 and 2.0 degree scenarios have been elaborated for the EU. One of the main scenarios that reaches climate neutrality by 2050 is illustrated in Figure 2.1. This scenario comprises i) a shift in diets with a reduced consumption of animal products; ii) technical mitigation options to reduce the non- $\mathrm{CO}_{2}$ emissions in agriculture by $\sim 30 \%$; and iii) increased carbon sequestration in land use (mainly through afforestation).

Given the growing population and with a changing climate, ecosystem and global land use, agriculture and forestry will play an important role in providing sufficient food and feed as well as supporting 
other sectors such as industry and construction sectors. There are strong potentials in reducing the non- $\mathrm{CO}_{2}$ emissions in agriculture relevant to the extension of smart agriculture, precision farming which allows optimising fertiliser and plant protection products. Moreover, innovative manure management methods such as biogas production and the carbon sequestration on land can also play a role. It should be noted that to achieve the net-zero GHG emissions, maintaining and increasing carbon sinks are as important as reducing emissions. In this sense, agriculture itself and basically nature-based solutions would provide multiple benefits via enhanced climate resilience and biodiversity.

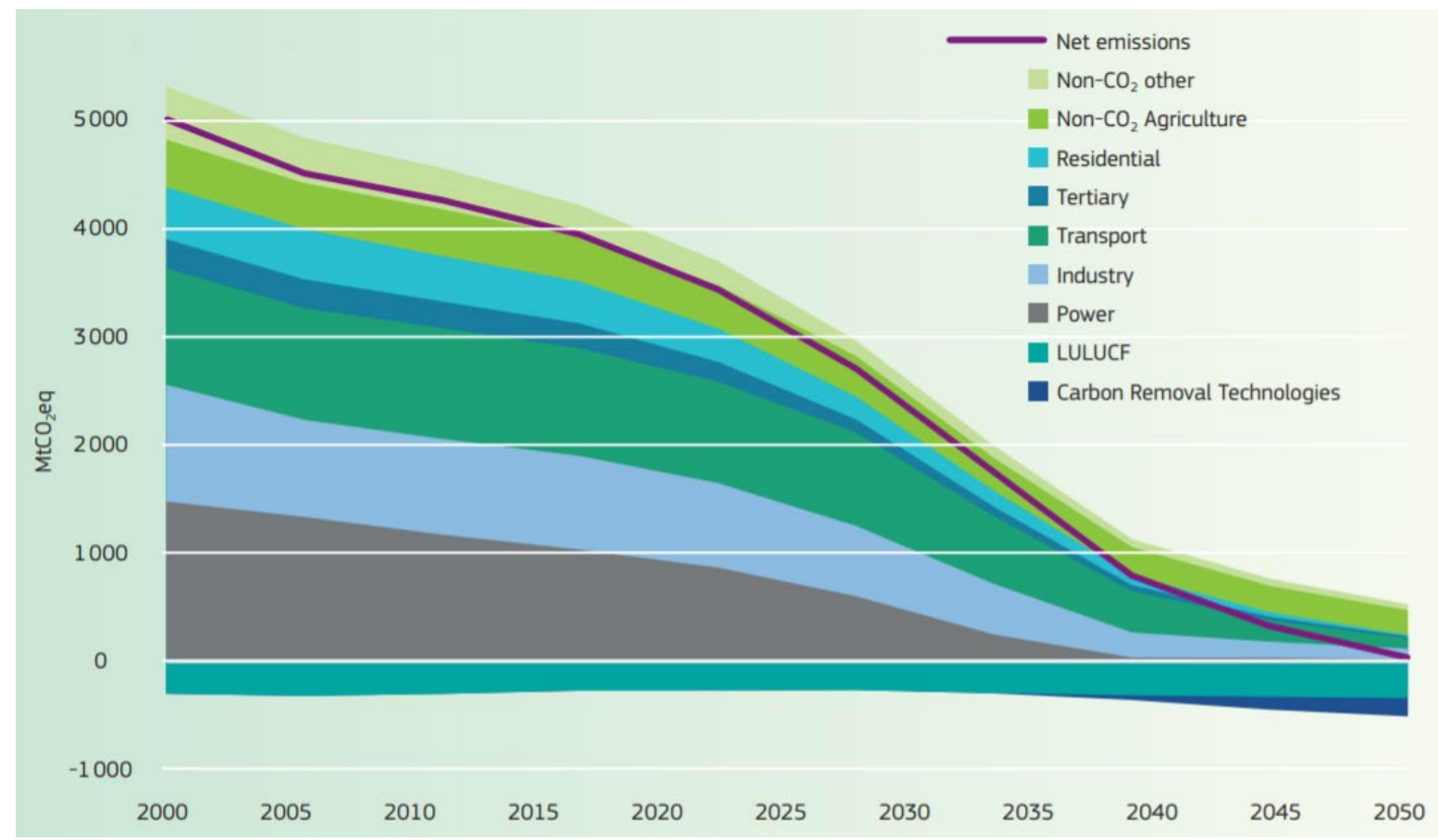

Figure 2.1 GHG emission trajectory in a $1.5^{\circ} \mathrm{C}$ scenario

Source: EC (2018).

Sustainable healthy diets level (EAT Lancet study)

For defining GHG targets for the food production system, it is important to also consider the way we consume food, as this determines the demand for different food products. Due to the absence of agreed targets for healthy food and sustainable food production, efforts have been made to reach a scientific consensus to define the targets. In 2019, the EAT-Lancet commission defined a scientific universal target for healthy diets and sustainable food production which allows us to feed up the growing world population by 2050 and help us to achieve the Paris agreement (Willett et al., 2019). This universal healthy target make it possible to estimate the health and environmental impacts of alternative diets compare to the reference diets. This EAT Lancet reference diet largely consists of vegetables, fruits, whole grains, legumes, nuts, and unsaturated oils, includes a low to moderate amount of seafood, dairy and poultry, and includes no or a low quantity of red meat, processed meat, added sugar, refined grains, and starchy vegetables.

This diet was developed using the planetary boundaries framework as a guide to propose a safe operating space for food systems that encompasses human health and environmental sustainability. For GHG emissions the amount of unavoidable emissions from food production until 2050 was assessed, which excludes all carbon dioxide emissions from burning of fossil fuels and from land use change, which were assumed to be been reduced to zero, and only methane and nitrous oxide associated with biological processes in crop and livestock production were considered. They proposed that global $\mathrm{CH}_{4}$ and $\mathrm{N}_{2} \mathrm{O}$ emissions from agriculture for food production should be kept at or less than 5 Gigatonnes of $\mathrm{CO}_{2}$ eq per year in 2050. This is not much lower than the current $\mathrm{CH}_{4}$ and $\mathrm{N}_{2} \mathrm{O}$ emissions from global agriculture, but this is combined with a large sink of $\mathrm{CO}_{2}$ in land use (after 2050), which is currently at global scale an emission source. This scientific target represents nearly 
half of the allowable global emissions from all sources in 2050 , consistent with the RCP2.6 and a $2^{\circ} \mathrm{C}$ temperature rise.

\section{Other studies}

Many attempts have been made to define the national sustainable healthy diets level. For example Chen et al. (2019) identified the standard healthy diets for Swiss and showed that to achieve the sustainable level, a great reduction in meat and vegetable oils, moderate reduction in cereals, roots, and fish products consumptions is needed while the legumes, nuts, seeds, fruits, and vegetables need to be consumed to a greater extent (Chen et al., 2019). Similar research was done by Broekema et al. (2020) to identify the standard diet level for Dutch adults. The results showed that to meet both the lowest GHG emission target (2050) and healthy food baseline, the high reduction in consumption of beef, pork, cheese, snacks, and butter is essential while the consumption of legumes, fish and shellfish, peanuts, tree nuts, vegetables, soy foods, and soy drink needs to be increased (Broekema et al., 2020). As it can be seen the obtained results emphasise the high consumption of livestock products which need to be reduced to meet the higher levels of sustainability.

\subsubsection{Determining the scope and system boundary for the reduction target}

The boundary for GHG reduction targets defines the scope of the assessment in terms of the range of GHG effects that are included in the GHG assessment. It is strongly recommended to apply a comprehensive assessment which includes the full range of effects considered to be significant. To identify the significant effects, the likelihood where each GHG effect will occur and the relative magnitude of each GHG effect should be evaluated. Sectoral targets may cover the emissions in the sector as well as the emissions out of the sector. For example, a target to reduce GHG emissions in the livestock production sector includes the emissions resulting from the livestock production (at the farm) as well as the emissions associated with the consumed inputs (feed, energy, etc.)(before the farmgate). It is recommended to define the sector according to the amount of control on GHG inventory. This helps to keep the consistency between the mitigation targets and GHG inventory.

The GHG Protocol Corporate Standard classified the sector GHG emissions into three scopes. Scope 1: emissions are the direct emissions that are produced during the agricultural production processes. For example, emissions as a result of enteric fermentation and manure storage in livestock production. Scope 2: emissions are indirect emissions associated with the production of purchased energy sources such as electricity. Scope 3: emissions are all indirect emissions (not included in scope 2) related to the agricultural production processes. These emissions are not directly under company control but they are related to production process. Scope 3 emissions are considered as the supply chain of agricultural products. These comprise the emissions related to the import of feed products (including land use change). Looking at the entire dairy chain (Figure 2.2), most of the GHG emissions from milk production are on the farm (primary production), about $60 \%$, whereas $25 \%$ are in the supply chain (mainly feed and mineral fertilisers production) and $15 \%$ in the processing post farm (downstream). The mentioned shares of GHG emission depends on the farming system. 


\section{Milk per kg (incl. LULUCF)}

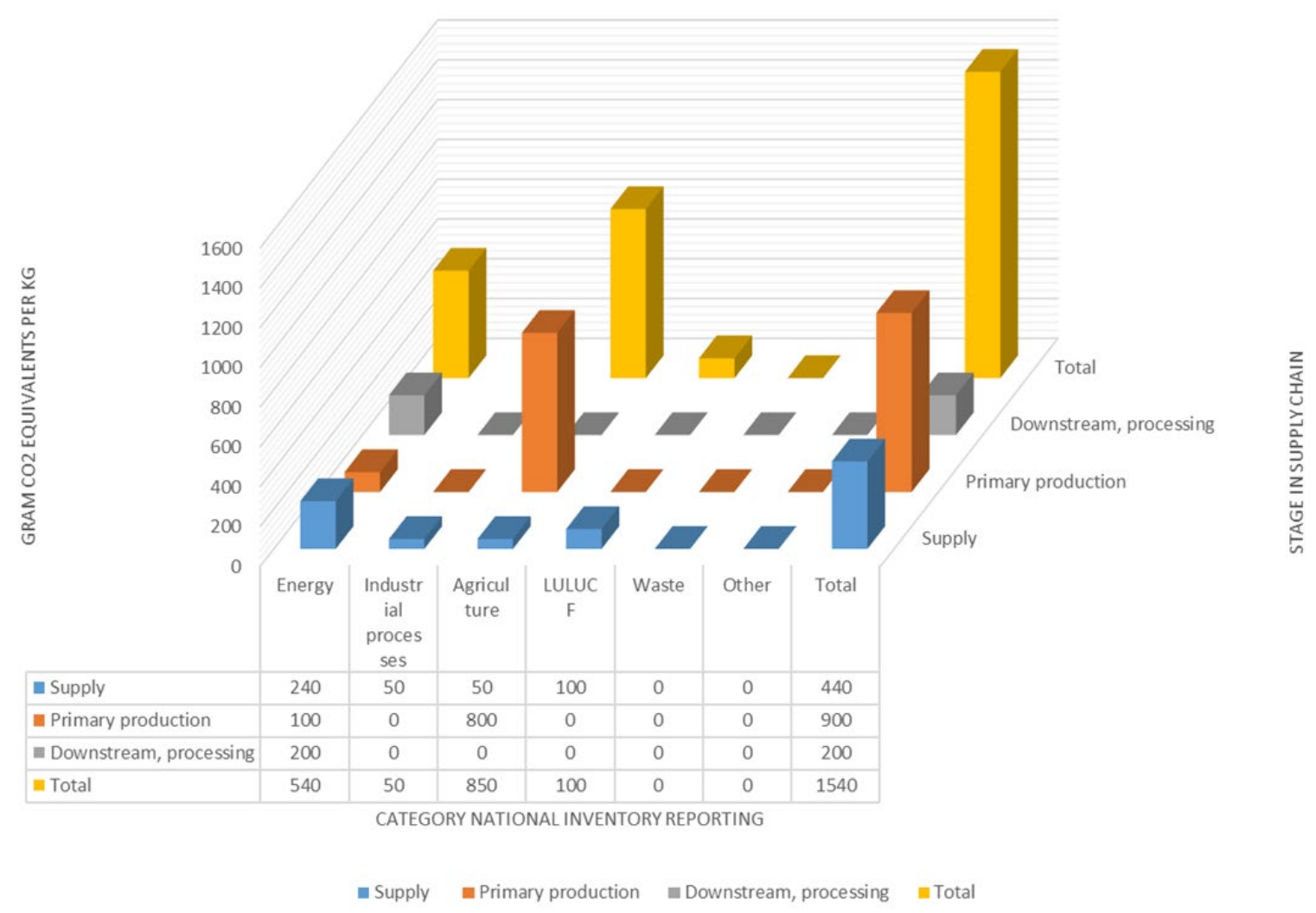

Figure 2.2 Illustration for the Netherlands where GHG emissions in the dairy chain occur and in which IPCC sector these emissions are reported

Source: T. Vellinga, Wageningen University \& Research.

There are benefits and drawbacks for choosing scope 1-2 versus scope 3 . For example, in the case that the scope is too limited, there are less incentives for farmers to reduce the GHG emissions. However, a broader boundary (scope 3) may decrease the focus on GHG mitigation strategies at farm level. Due to the fact that emissions associated with the feed production contributing significantly to the total GHG emission of the livestock production process, scope 3 plays an important role to the GHG mitigation strategies in this sector. On the other hand, for the measurement of the scope 3 emissions it is essential to go deeper into the value chain, which complicates monitoring.

National targets are often linked to the national inventories, which are based on the IPCC emission sectors. In this case the emissions from the IPCC emission sector agriculture only comprised the non$\mathrm{CO}_{2}$ emissions from enteric fermentation, manure management and direct and indirect $\mathrm{N}_{2} \mathrm{O}$ soil emissions. Emissions from energy use and land use change are not included under this emission sector (see also Figure 2.2). Dairy companies and dairy sectors usually work according a chain approach towards a product carbon footprint. It is important to be aware of this difference in orientation of the chain approach that is common in business and the (national) sectoral orientation of the government. Some effects of efforts by the dairy sector to improve the product carbon footprint (e.g. less use of imported feed) do not become visible and do not count in the national inventories.

\subsubsection{How to get to national sectoral or farm level targets}

Once the ambition level, the fair share in the emission reduction and the scope and system boundaries have been determined, they have to be translated to targets at the relevant scale. This can either be at sector level or farm specific targets can be used. Also, regional targets can be set, if production circumstances are very different. For example, in the Netherlands the dairy farms on peat soils will have higher emissions from peat drainage, compared to farmers on sandy or clayey soils. 
If a national target is available, it is best to link the sector/farm level targets to this national target. Ideally the emission reduction should be allocated to farms according to their mitigation potential. This will ensure that early adopters of mitigation measures are not in disadvantage. However, at this stage there is probably insufficient information available to determine these farm specific mitigation potentials. An alternative would be a more general reduction target for the shorter term (e.g. 2025), which can be replaced later by a farm specific reduction target.

\subsubsection{Type of reduction target}

Intensity based versus total amount target

GHG reduction targets can be set in different ways, an important distinction is an intensity based target, i.e. expressed in $\mathrm{kg} \mathrm{CO} 2$ eq. per $\mathrm{kg}$ milk, versus an absolute target expressed in ton $\mathrm{CO}_{2}$ eq. Intensity targets are often used in sector initiatives, which consider the full dairy chain, whereas absolute targets are often set in the national context.

The problem with intensity targets is that total emissions can still increase if the total milk production is increasing. Intensity targets without constraints on the total emissions, are therefore not in line with the final target for the Paris Agreement. On the other hand, if targets are expressed in terms of total emission for the entire sector/country, the risk exist that production is replaced to other countries, where less strict climate policies are implemented, which might even lead to an increase in emission. This relocation of emissions, so-called carbon leakage, can undermine the effectiveness of the environmental policies, since for climate change impact it doesn't matter where the emissions are occurring.

At farm level, it is more difficult to manage at a total target, as this assumes stable livestock numbers, where in reality farms are expanding or decreasing in size. In intensity based target would in that way be more flexible as it is independent of the size of the farm. However, an intensity based target is often favouring intensive farming systems with high milk production per cow, whereas more extensive farming systems will have a much lower emission per ha, but often higher emission if it is expressed per $\mathrm{kg}$ of milk. The recommended approach would be an intensity target at farm level (per kg of milk), but including also an absolute target at country/sector level.

\section{Absolute versus relative target}

Another choice to be made is whether the target should be an absolute reduction target, e.g. a reduction of $0.1 \mathrm{~kg} \mathrm{CO} 2$ eq per $\mathrm{kg}$ milk, or relative reduction target, e.g. a $10 \%$ reduction in GHG emissions. Especially for a target at farm level this distinction is important, as the starting point (baseline) can be very different amongst farmers, and also the mitigation potential is dependent on specific farm conditions and management. For a farmer that already produces milk with a low GHG footprint, it will be difficult to comply with an absolute emission reduction target, compared to a farmer with a high footprint, who has not taken yet much mitigation measures. A relative target is in that way more fair, as probably a similar effort is required to comply with the target.

Another option is to define absolute levels for intensity target (e.g. a level of $1.0 \mathrm{~kg} \mathrm{CO} 2$ eq per $\mathrm{kg}$ milk). The advantage is that well performing farms are rewarded and that less performing farms are forced to improve. It will probably be necessary to differentiate these levels. E.g. in the Netherlands differentiation for soil (peat) would be relevant.

\section{Short term versus long term}

The final issue to take into consideration is the time horizon for which the target is set. In order to align with the Paris Agreement a long-term target for 2050 would be required. However, for climate change mitigation it is not the emission reduction in 2050 that counts, but the cumulative emission reductions during the period till 2050, as the impact on global temperature is determined by the carbon budget. Therefore, early emission reductions will have a stronger impact compared to late emission reductions. It is therefore good practice to set a pathway towards a long-term target, with intermediate targets to steer on, for example a target for every 5-year period. 
An aspect to take into account for long-term targets are changes in the metrics, especially for the non- $\mathrm{CO}_{2}$ greenhouse gasses, for which the Global Warming Potential (GWP) is used to make these emissions comparable to the $\mathrm{CO}_{2}$ emissions. The science beyond these GWP values is complex and still under development. Over the last decades the GWP values have changed in the different versions of the IPCC assessment reports. An overview is provided in Table 2.4. These values are calculated over a 100-year time horizon. In addition, in the latest IPCC AR5 report, also GWP values including the so called climate carbon feedback are provided, which refers to the effect that a changing climate has on the carbon cycle, which impacts atmospheric $\mathrm{CO}_{2}$, which in turn changes further the climate. For $\mathrm{CH} 4$ the GWP value including the climate carbon feedback is with 34 even higher. These changing values can have a significant impact on the share of the total GHG emissions.

Table 2.4 Global Warming Potential (GWP) values from different IPCC reports

\begin{tabular}{|l|l|l|l|l|}
\hline \multirow{2}{*}{$\begin{array}{l}\text { Industrial } \\
\text { designation } \\
\text { or common } \\
\text { name }\end{array}$} & Chemical formula & $\begin{array}{l}\text { Second } \\
\text { Assessment } \\
\text { Report (SAR) }\end{array}$ & $\begin{array}{l}\text { Fourth } \\
\text { Assessment } \\
\text { Report (AR4) }\end{array}$ & $\begin{array}{l}\text { Fifth Assessment } \\
\text { Report (AR5) }\end{array}$ \\
\hline Carbon dioxide & $\mathrm{CO}_{2}$ & 1 & 1 & 1 \\
\hline Methane & $\mathrm{CH}_{4}$ & 21 & 25 & 28 \\
\hline Nitrous oxide & $\mathrm{N}_{2} \mathrm{O}$ & 310 & 298 & 265 \\
\hline
\end{tabular}

Recently there is also a debate on the contribution of short-lived greenhouse gases, such as $\mathrm{CH}_{4}$, versus long-lived greenhouse gases, such as $\mathrm{CO}_{2}$ and $\mathrm{N}_{2} \mathrm{O}$. The conventional GWP approach does not fully reflect the true behaviour of short-lived climate pollutants and an alternative GWP approach has recently been developed (Allen et al., 2018). However, there is still a lot of debate about this difference and how to deal with this in emission accounting systems. From the livestock sector there is a push to use this metric as it changes the role of ruminants in the climate discussion, as there would be less need to reduce $\mathrm{CH}_{4}$ emissions, while at the other side a decreasing livestock population could even contribute to cooling. First the scientific consensus should be reached, which will probably be published in the next IPCC assessment report, expected to be published in 2021.

To conclude: the methodology behind the target setting should be flexible and be able to take account of changes in metrics, which might change over time. This is not just about GWP but more general about all elements of the model to estimate GHG emissions.

\subsection{Recommendations}

As stated before in the introduction, this feasibility study will not provide specific targets for the dairy sector that financial sector can use, as the target setting process involves choices that are rather societal/political choices than scientifically based decisions. However, we can give some recommendations, which can be further elaborated in a follow-up project, to further specify potential targets or pathways towards the targets of the Paris Agreement.

Based on the steps of the figure presented in Chapter 2.1 we present the following recommendations:

- Setting a fair share in emission reduction for food products is very difficult, so as long as there is no specific methodology available, it is best to align with national targets and emission trajectories, such as the EU long-term climate strategy. Alternatively, scenarios of emission reduction pathways can be developed in collaboration with the relevant stakeholders.

- Ensure that the system boundary is in line with the possibilities the actor has for taking interventions: in the case of a farmer the system boundary should be farm gate, i.e. the on-farm emissions and emissions related to external inputs such as feed. 
- Targets including scope 3 offer a wider range of mitigation options and prevent emission leakage, but at the same time monitoring becomes more complicated.

- Be aware of the differences between the national inventories, which are based on the IPCC emission sectors and the LCA targets that are often used by dairy companies.

- Targets including carbon removals (e.g. (soil) carbon sequestration) should obtain the carbon removals within the dairy chain, i.e. in-setting rather than off-setting.

- An intensity-based target is most easy to implement at farm level. An intensity-based target is also fair, because the exact location of GHG is irrelevant. However, this should also include a cap on the total emissions on sector or national level to ensure that the targets contribute to the final objective of the Paris Agreement.

- A long term target is required for the long term perspective and ambition, but in addition shorter term targets are required to ensure timely action and alignment with available mitigation options.

- The target-setting methodology should be flexible and be able to take account of changes in metrics, such as GWP, which might change over time. 


\section{Tools and monitoring}

\subsection{Introduction}

Banks need robust GHG targets and measurements for their global F\&A portfolio. Tools with sound metrics are necessary to monitor progress in meeting such targets. An explorative investigation has been carried out within four of the most relevant countries in the dairy sector (New Zealand, Australia, USA, and The Netherlands), with the aim of collecting information about available relevant GHG emissions monitoring tools. We selected tools that meet certain basic requirements, such as:

- The tool is meant for use by farmers to monitor their specific GHG emissions.

- The tool is currently used by dairy farmers.

- The tool is granular enough to measure the GHG impact of mitigation options.

- The applied methodology and background data used are clearly documented.

Only tools were investigated that met most of the above requirements. So tools that are only used by $\mathrm{R} \& \mathrm{D} /$ researchers and are too complex/detailed to be used by farmers or the dairy industry are not included.

Tools implement calculation rules based on national or sector guidelines. In the following paragraphs some relevant guidelines are introduced. Then, the results of the investigation per country are presented. The final paragraphs provide an overview how these tools (and potentially new tools) could be selected and combined for monitoring on farm, region and global level.

\subsection{Most relevant methodological guidelines for the dairy industry}

This section describes the most relevant global dairy specific methodological guidelines that are used as reference documents in tools. The guidelines are meant to achieve a certain global level playing field in GHG assessments so dairy footprints can be aggregated/compared in the future. Countryspecific guidelines / National Inventory Reports (NIR) are discussed when relevant for farm level monitoring in the country sections.

$I D F$

The international dairy federation (IDF) published in 2015 a common carbon footprint approach for the dairy sector. A specificity of this guideline, which was copied into other guidelines (like the European $\mathrm{PEF}$ ), is the biophysical allocation approach for milk, calves and slaughter cows. ${ }^{9}$ IDF is currently finalising a project ( $\mathrm{C}$-Sequ project) in which guidelines are developed how soil carbon sequestration could be implemented in future GHG assessments.

\section{EDA/European Commission}

The European Dairy Association (EDA) published in 2018 their Product Environmental Footprint Category Rules (PEFCR) for dairy. This standard follows the general rules from the European Commission (EC) published in the PEFCR guidelines and provides more dairy specific rules. Currently the EC is investigating several policy options (e.g. green claim initiative) to make these standards part of legislation. The most relevant rules for dairy in these guidelines are:

- How renewable energy generation/credits have to be treated over the producer/consumer.

- Allocation between milk, calf and cows (same as IDF).

- How enteric fermentation shall be calculated (IPCC TIER 2 method is the baseline, higher country specific TIER 3 levels are allowed but not in comparisons).

\footnotetext{
${ }^{9}$ Based on how the cow itself allocates the feed inputs over milk, pregnancy (e.g. calf) and growth
} 
- How Land Use Change (LUC) emissions shall be calculated.

- How to deal with carbon sequestration. ${ }^{10}$

- Specific guidelines on how to include scope 3 GHG emissions like feed and fertilisers.

- Et cetera.

\section{LEAP}

Livestock Environmental Assessment and Performance Partnership (LEAP) is a multi-stakeholder initiative that seeks to improve the environmental sustainability of the livestock sector through harmonised methods, metrics, and data. LEAP leads a coordinated global initiative to accelerate the sustainable development of livestock supply chain and to support coherent climate actions, while contributing to the achievement of the 2030 Agenda for Sustainable Development and the Paris Agreement. One of the guidelines developed by LEAP is the guideline to assess the environmental performance of large ruminants. LEAP also developed a guideline how soil carbon sequestration could be measured/modelled in livestock systems.

Regarding the selection of applicable TIER level for GHG emissions calculations (e.g. enteric fermentation) the highest available level in a country should be used.

\subsection{Results of tools and data availability investigation}

\subsubsection{New Zealand}

New Zealand is one of the main global dairy producers. Every year, New Zealand exports about $95 \%$ of its produced milk with dairy products accounting for approximately $20 \%$ of the total exports' earnings of the country. ${ }^{11}$ Domestic consumption of milk is also considerable, amounting to $105 \mathrm{~kg}$ per capita in 2018, one of the highest consumption rates in the world. New Zealand operates mainly pasture-based farming, with large herds and large-scale processing facilities ${ }^{12}$. Up to $2017,73 \%$ of herds were located in the North Island.

\section{Results tools}

The investigation on the availability of GHG emissions monitoring tools and database in New Zealand showed a limited abundancy of possibilities. This is likely the result of major efforts applied in the last years into the development and diffusion of the Overseer tool, described further on.

The Farm Carbon Footprint Calculator is a freely available online tool first launched in 2008 by Lincoln University. It was developed by the Agribusiness and Economics Research Unit (AERU) at Lincoln University and the engineering consultancy Agrilink NZ. The tool is fairly simplistic, and mainly targets individual farmers that can use this tool independently to get an idea on the GHG emissions related to their animal farms. The system boundaries are cradle-to-farm gate, and the background data based on the New Zealand Greenhouse Gas Inventory (2016). However, the tool has not been updated since 2016. For the tool to work, few inputs are needed and usually are very easy to gather (for instance, farm area, stock type, number of heads, production.

OverseerFM is an online software that wants to connect farmers to science for supporting sustainable farming. ${ }^{13}$ It is specifically developed for the New Zealand context and owned by AgResearch Limited, the Fertiliser Association of New Zealand and the Ministry for Primary Industries. Overseer is an agricultural management tool that allows assessing the nutrient use and movement within the farm, supporting the production optimisation and the reduction of nutrient losses. Overseer models the

\footnotetext{
${ }^{10}$ Currently not accepted in PEF: 'Soil carbon uptake (accumulation) shall be excluded from the footprint results as it is highly questionable how the long term uptakes (beyond 100 years) can be guaranteed in practice. For example, from grasslands or improved land management through tilling techniques or other management actions taken in relation to agricultural land.' Soil carbon storage may be included in the PEFCR as additional environmental information when proof is provided.

11 https://www.dcanz.com/about-the-nz-dairy-industry/

12 https://www.statista.com/topics/6069/dairy-industry-in-new-zealand/

13 https://www.overseer.org.nz/
} 
nutrient flows in a farming system and can be used to identify potential risks to the environment through the calculation of nutrient loss through run-off, leaching, and greenhouse gas emissions. The tool works per subscription as every farmer has to subscribe for 360 dollars per year per farm.

It can be used to assess the most common farming systems in New Zealand including dairy, sheep and beef, dairy goats, deer, outdoor pigs, viticulture, and a range of vegetables and arable crops. If a certain crop is not available, they ask the farmer to get in touch for future updates. The system boundaries are cradle-to-farm gate. Several methods are applied depending on the sub-modules (for more details, see the report 'technical manual: carbon dioxide emissions v. 6.3). ${ }^{14}$ Enteric methane emissions are calculated by multiplying the total Dry Matter Intake (DMI from pasture, supplements, and crops) by an enteric methane emission factor specific for New Zealand. DMI is estimated monthly from the animal's energy requirement and feed ME content. Overseer is made of sub-modules to model nutrient flows and GHG emissions. The main sub-modules are: supplement component; crops component; animal model; DMI component; pasture component; climate model; soil component; hydrology model; irrigation model; wetlands model.

The Overseer includes a detailed sub-model to calculate the animal metabolisable energy (ME) requirement, that are used to estimate the animal's pasture intake. In particular, the sub-model estimates both DM and nutrient intake. More detailed information can be found in the 'technical manual: Animal metabolizable energy requirements'.

Background data is extracted from: Ecoinvent, New Zealand Greenhouse Gas Inventory, scientific literature.

Overseer has a long history of collaboration between the government, the fertiliser industry, and agricultural scientists. It is the most widely and known tool of its kind in New Zealand, used by individual farmers as well as Regional Councils. Despite its broad use, Overseer remains a tool specifically designed for New Zealand. Fonterra, one of New Zealand major dairy producers, implemented Overseer within its farms in the past, especially within a project of nitrogen management where Overseer's raw model has been integrated into Fonterra's farm reporting system. ${ }^{15}$ Fonterra is not using Overseer to assess GHG emissions on their supplying farms. Fonterra applies a model based on the National Inventory Report (NIR) - called AIM - and supplies the GHG results to the dairy farmers. This model is not aligned with Overseer.

\section{Monitoring initiatives}

Below overview (Figure 3.1) was provided by Nick Tait from DairyNZ. The overview includes also the tools which are used by the different dairy processers in NZ. It can be concluded that there is only one relevant whole-farm tool in use by dairy farmers which is Overseer. The AIM is applied by Fonterra itself and the results are provided to the dairy farmers.

\footnotetext{
14 https://www.overseer.org.nz/our-science

15 https://www.fonterra.com/nz/en/campaign/tiaki.html
} 
Table 3.1 Overview of tools used in the dairy sector in New Zealand for monitoring Source: Nick Tait, DairyNZ.

\begin{tabular}{|c|c|c|c|c|c|c|c|c|c|}
\hline \multicolumn{2}{|l|}{ Question } & Fonterra & Miraka & Tatua & Synlait & $\begin{array}{l}\text { Mataura Valle } \\
\text { y Milk }\end{array}$ & $\begin{array}{l}\text { Westland Mil } \\
\mathrm{k}\end{array}$ & Oceania & $\begin{array}{l}\text { Open Countr } \\
\text { y Dairies }\end{array}$ \\
\hline \multicolumn{2}{|c|}{$\begin{array}{l}\text { Are you reporting this } \\
\text { year? }\end{array}$} & Yes & Yes & Yes & Yes & Not yet & Not yet & Yes & Not yet \\
\hline \multicolumn{2}{|c|}{$\begin{array}{l}\text { What model are you } \\
\text { using? }\end{array}$} & $\begin{array}{l}\text { Agricultural } \\
\text { Inventory } \\
\text { Model } \\
\text { (AIM) }\end{array}$ & Overseer & Overseer & Overseer & $\mathrm{N} / \mathrm{A}$ & $\begin{array}{l}\text { Trying } \\
\text { to avoid } \\
\text { Overseer }\end{array}$ & Overseer & $\mathrm{N} / \mathrm{A}$ \\
\hline \multirow{3}{*}{$\begin{array}{l}\text { What } \\
\text { metrics are } \\
\text { you using? }\end{array}$} & Per ha & $\sqrt{ }$ & $\sqrt{ }$ & & $\sqrt{ }$ & & $\sqrt{ }$ & $\sqrt{ }$ & \\
\hline & Per kg MS & $\sqrt{ }$ & $\sqrt{ }$ & $\sqrt{ }$ & $\sqrt{ }$ & & $\sqrt{ }$ & $\sqrt{ }$ & \\
\hline & Per Cow & & $\sqrt{ }$ & & $\sqrt{ }$ & & & & \\
\hline
\end{tabular}

An initiative worth mentioning is that of Synlait, which started reporting over its GHG emissions under its new sustainability strategy (Synlait, 2019). Within the strategy, it aims at reducing off-farm emissions by $50 \%$ per $\mathrm{kg}$ of product and in-farm emission by $35 \%$ per $\mathrm{kg}$ of milk solids within 10 years. Their methodology follows the GHG Protocol and ISO 14064-1:2018 standards.

\subsubsection{United States}

The United States always held a secured position in the dairy sector, thanks to advantageous resources and land availability and constant investment in farming practices (Today, 2014). The majority of American dairy farms are family businesses and are concentrated in the western and northern areas of the country and organised in several cooperatives. ${ }^{16}$ In recent years, the dairy sector has experienced a trend of decrease in dairy operations and an increase in the number of cows per operation.

\section{Results}

The U.S industry whole-farm GHG tool is the National Milk Producers Farmers Ensuring

Responsible Management (FARM ES). Over $70 \%$ of the U.S. milk supply has pledged to achieve statistical sampling of their farms while some cooperatives are committed to evaluating every farm. At present, $78 \%$ of the milk supply implements this tool - generally through cooperatives - to some extent. The tool is facilitated and supported by certified evaluators (so not self-assessment). This assures consistency and accuracy of data entry. The output of the tool is per kg FPCM and scope 1, 2 and 3 emissions sources are in scope. FARM ES recommends conducting a stratified random sample of farms to enrol in FARM ES rather than targeting all of its farms. Since 2017, there have been over 1,600 FARM ES evaluations conducted on over 1,300 U.S. dairy farms.

The Comet Farm tool is a farm and ranch accounting system for GHG emissions. ${ }^{17}$ It allows the user to evaluate different strategies to reduce GHG emissions and/or sequestering more carbon. The livestock module requires data on herd size and composition, manure management, feed intake, and feed characteristics. Emissions are estimated using statistical models based on information from either the United States Department of Agriculture (USDA) or scientific literature, and similar to the models implemented in the US National Inventory.

Biomass $\mathrm{CO}_{2}$, soil $\mathrm{CO}_{2}$ and $\mathrm{N}_{2} \mathrm{O}$ emissions/removals are calculated using the DayCent simulation model, with optional empirical models for biomass stocks in agroforestry systems (Paustian et al., 2018). Livestock emissions from enteric fermentation and from manure management are estimated from empirical models using basic livestock characteristics or with more detailed information on feeding regimes, when available.

\footnotetext{
16 https://www.ers.usda.gov/topics/animal-products/dairy/

17 http://comet-farm.com/
} 
The methodology underlying the Comet Farm tool is based on the USDA's GHG methods (Eve et al., 2014). Data inserted by the user is privately stored, allowing the farmer of periodical updates. Comet Farm can also be used without registration, in which case data is only temporarily stored.

The Dairy Gas emission model is another software for estimating emissions of GHGs, ammonia, hydrogen sulphide and volatile organic compound from the dairy sector (Rotz et al., 2015). The model allows for scope 2 and scope 3 assessments, as the emissions related to the use and production of machinery, electricity, feed, and fertilisers are included. The analysed activities include manure storage and management, feed management, enteric fermentation and feed and crops cultivation. $\mathrm{CO}_{2}$ equivalents are calculated according to the Global Warming Potentials (GWPs) as indicated in the fourth IPCC Assessment Report (e.g. $\mathrm{N}_{2} \mathrm{O}$ and $\mathrm{CH}_{4}$ respectively 298 and $25 \mathrm{~kg} \mathrm{CO}$ eq/kg).

\section{Monitoring Initiatives}

The University of Illinois has been awarded USD 4.5 million from the U.S. Department of Energy's Advanced Research Projects Agency-Energy (ARPA-E) through the SMARTFARM programme. ${ }^{18}$ The programme will focus on how to calculate farm-scale carbon credits, allowing farmers to understand the value of their agricultural practices in the perspective of carbon trading markets. This initiative will initially focus on the US sector but aims at being applied on a bigger scale, through innovation in the fields of aerial data collection, mobile soil sensing and supercomputing.

\subsubsection{Australia}

The Australian dairy industry has a pivotal role in the Australian primary sector, being the third largest industry. Only preceded by wheat and beef production. ${ }^{19}$ Also, Australia is the world's third largest exporter of dairy and up to $50 \%$ of the national production is exported (Bills, 2004). The production is mainly located in the south-east of the country, where the state of Victoria is the main producer. In 2019, milk production reached 8.8 billion litres. The Australian dairy sector is facing severe pressure in recent years due to stronger droughts and variations in the rainfall usual patterns. ${ }^{20}$ Similarly, agricultural productivity dropped drastically over the droughts occurring in the last two decades (Sheng and $\mathrm{Xu}, 2019$ ).

\section{Results}

The landscape of the dairy sector in Australia transformed since the setting of the 2030 agenda, containing four main commitments that range from the enhancement of the sector's economic viability to better animal care and reduced environmental impacts. The Australian dairy industry aims at reducing GHG emissions intensity of $30 \%$ by 2030 from the 2015 baseline (Australia, Dairy report, 2019). Part of this ambitious commitment is the development and improvement (e.g. more consistency) of monitoring tools specific for the dairy sector, coupled with sustainability frameworks that drive the sector towards new sustainability-driven priorities. Consequently, the investigation shows a good availability of both monitoring tools and GHG emissions reduction initiatives.

The Dairy Greenhouse Accounting Framework (D-GAF) is a freely available tool that aligns with the methods as applied in the Australian National GHG Inventory (NGGI). ${ }^{21}$ Together with the D-GAF, other modules are available for calculating emissions related to beef, sheep, and grains production. The D-GAF calculated scope 1 and scope 2 emissions (so mainly gate-to-gate system boundaries), although it includes a section for calculating carbon sequestration from trees. The data requirements are quite exhaustive, and they cover inputs like liveweight, crude protein content of feed, DM digestibility, fertilisers for crops and pasture, energy use, manure management, soil type. The GWP values are applied as indicated in the IPCC Fourth Assessment Report (e.g. $\mathrm{N}_{2} \mathrm{O}$ and $\mathrm{CH}_{4}$ respectively 298 and $25 \mathrm{~kg} \mathrm{CO} 2 \mathrm{eq} / \mathrm{kg}$ ). The tool has been updated in 2020. Based on the current information we don't get the impression that D-GAF is used by dairy farmers.

\footnotetext{
18 https://emails.illinois.edu/newsletter/1642301134.html

19 https://www.dairyaustralia.com.au/

20 https://www. dairyglobal. net/Market-trends/Articles/2019/10/Australias-dairy-sector-still-facing-immense-pressure492403E/

${ }^{21}$ http://www.greenhouse. unimelb.edu.au/Tools. htm
} 
The Australian Dairy Carbon Calculator (also known as the Dairy Greenhouse gas Abatement Strategies-DGAS) was developed to allow farmers to calculate the impact of different GHG emissions reduction strategies that would best suit their farming system. The tool includes four categories of reduction strategies: herd management, feeding management, soil management, and farm intensification. The tool is developed in Excel and was lastly updated in 2017. The GHG emissions are calculated based on the NGGI methodology and include scope 1 and scope 2 (so mainly gate-to-gate system boundaries). Users are requested to insert data on: livestock numbers, liveweight, daily dietary intakes (DM), milk production, DM digestibility, crude protein, fertilisers for pasture and crops, energy use, purchased feed, manure management. Once the farm baseline is created based on these inputs, the user can explore the different GHG reduction strategies and learn about the potential benefits for their farm both in terms of economic return and GHG emissions reduction. Also, variations in production are analysed and displayed. This tool is used by dairy farmers and the amount of users will probably increase the coming years. DairyBase is a farm financial program that enables farmers to submit their financial data and it uses this to calculate the profitability, EBIT, ROTA etc for farms. Over 1,400 dairy farms (out of 5,200) are using DairyBase. In 2021 it will be connected to the Australian Dairy Carbon Calculator and available for farmers.

\section{Monitoring Initiatives}

The Australian Government funded research through the Climate Change Research Program with the aim of developing on-farm strategies to reduce the GHG emissions from livestock. ${ }^{22}$ The research is focusing on the investigation over methane emissions measuring tools, testing their applicability and effectiveness. The funding is part of a larger umbrella of initiatives part of the governmental programme Australia's Farming Future. ${ }^{12}$

Moreover, the Australian Government incentives businesses that are willing to cut down their emissions through innovation, within a project called Emissions Reduction Fund (ERF). ${ }^{23}$ The projects might belong to the agricultural sector, where participants can earn credits for every ton of $\mathrm{CO}_{2}$ emission reduced or captured and stored. Several methodologies for crediting emissions reduction of a certain activity and/or project are provided by the ERF. Two of these methodologies are relevant for the dairy sector: 'reducing GHG emissions in milking cows through feeding dietary additives' and 'animal effluent management'. ${ }^{24}$

Another noteworthy project is The Dairy Farm Monitor Project, a comprehensive financial and production analysis that accounts for 75 dairy farms spread evenly across 3 dairy regions: southwestern Victoria; Gippsland; northern Victoria. The project runs for 13 years and it has been a valuable reporting instrument for the Australian government and in general the dairy sector stakeholders in sharing information on the status of the industry (Victoria D.E.P.I, 2019).

\subsubsection{The Netherlands}

\section{Results}

Kringloopwijzer is a tool used by all 16,000 dairy farmers and by all dairy processors in the Netherlands. The tool has been initiated by a consortium of relevant Dutch stakeholders in the dairy sector. The tool development is currently performed by Wageningen University and Research. All dairy farmers are obligated to use the tool by the dairy processors. Kringloopwijzer also provides the government with the option to convert a general policy into a custom-made policy because more data/insights are available. Currently the effect of some mitigation options (e.g. additives resulting in less manure GHG emissions, fertilisers with less impact) is not reflected in the results. The tool is constantly in development. Besides GHG emissions, Kringloopwijzer quantifies other relevant indicators and environmental impacts such as 'Protein from own land' and 'Permanent pastures'.

The goal of Kringloopwijzer is a future-proof and responsible dairy sector in the Netherlands. The scope are all dairy farmers in The Netherlands from cradle-to-farm gate. The applied method (Van Dijk

\footnotetext{
22 https://www.agriculture.gov.au/ag-farm-food/climatechange/australias-farming-future/livestock-emissions

23 https://www.industry.gov.au/funding-and-incentives/emissions-reduction-fund

24 https://www.legislation.gov.au/Series/F2013L01554

https://www.legislation.gov.au/Series/F2020L00005
} 
et al., 2020) is approximately in line with the rules from the PEFCR dairy (The European Dairy Association, 2018). Some of the most relevant methodological points are:

- The use of GWP100 from the IPCC AR5 (e.g. $\mathrm{N}_{2} \mathrm{O}$ and $\mathrm{CH}_{4}$ respectively 298 and $34 \mathrm{~kg} \mathrm{CO} 2 \mathrm{eq} / \mathrm{kg}$ ).

- Country-specific tier 3 method to calculate enteric fermentation emissions.

- Biophysical allocation of the upstream burden to milk and meat is applied.

- The inclusion of Land Use Change emissions is applied.

The feed intake is based on the requirements of the cows and the nutritional composition of all feed ingredients in the ration. This nutritional information must be supplied by the farmers.

Kringloopwijzer is based on farmer-specific data. Currently, the upstream emissions of concentrate production are defaults, but this will become company-specific data by connecting data from most compound feed companies to Kringloopwijzer. Other background data and emission factors mainly come from literature, Feedprint and IPCC. For dairy farmers using the Kringloopwijzer is a licence to produce. The Kringloopwijzer is widely accepted and used by all farmers. Farm data is stored in a central database and the farmer can manage who is able to access/use his/ her data. The data of all farmers can be anonymously used for research by the government.

\section{Monitoring Initiatives}

The Dutch dairy sector has set up a joined initiative 'Sustainable Dairy Chain' ${ }^{25}$ organised by the dairy processors and farmers unions. Within this initiative around 2010 targets have been for 2020 set for several sustainability themes. One of the themes is climate neutral development, specified in sub goals for reduction of greenhouse gas emissions, production of sustainable energy and improvement of energy efficiency. A yearly monitoring report is published in which the progress against the targets is assessed (Doornewaard, 2020).

The Dutch foundation SMK published a certification scheme for more sustainable dairy, under the international environmental label 'On the way to PlanetProof'. PlanetProof has an integral approach to sustainability of which a maximum carbon footprint per $\mathrm{kg}$ of milk is one of the requirements. The Kringloopwijzer is used to monitor this carbon footprint. In order to be allowed to use the label, production of milk has to comply to a certain carbon footprint per kg milk. Participation is open for all dairy producers who adhere to the criteria. Certain dairy processors provide a premium for milk from planetproof.

\subsubsection{Non-regional specific tools}

\section{GLEAM}

The Global Livestock Environmental Assessment Model (GLEAM) is a tool from the FAO and is a GIS framework that simulates the bio-physical processes and activities along livestock supply chains based on LCA (multi-impact) approach. The basis of the GIS model is an advanced MS xls model complemented with global dairy industry data collected by the FAO. The tool can be used on a country-level but also on farm-level.

\section{$E X-A C T$}

EX-ACT is a tool from the FAO. This tool is purely land oriented (sink and source) and is as such not fit to monitor animal production systems from a life cycle perspective. It could be connected to other tools to assess soil carbon sequestration. Please note that the international dairy federation (IDF) is currently finalising a project ( $\mathrm{C}$-Sequ project) in which guidelines are developed how soil carbon sequestration could be implemented in GHG assessments of dairy farms.

\section{Cool Farm Tool}

The Cool Farm Tool (CFT) is developed by the Cool Farm Alliance (CFA). Members of the CFA are mainly food and beverage producing companies. The Cool Farm Tool is free for famers and organisations that use the tool pay to become CFA members. The tool consists of several modules

\footnotetext{
${ }^{25}$ Duurzame Zuivelketen. https://www. duurzamezuivelketen.nl/en/
} 
(e.g. rice, arable cultivation), the dairy module is one of them. The scope of the dairy tool is from cradle-to-farm gate.

Data can be shared in the tool with other users who can analyse and aggregate the data/results.

Relevant methodological considerations are:

- Biophysical allocation between milk and meat is applied which is compliant to the IDF guide (IDF, 2010) and the PEFCR for dairy (European Commission, 2018).

- The GWPs of the fourth IPCC Assessment report are used in the tool (e.g. $\mathrm{N}_{2} \mathrm{O}$ and $\mathrm{CH}_{4}$ respectively 298 and $25 \mathrm{~kg} \mathrm{CO} 2 \mathrm{eq} / \mathrm{kg}$ )

- Emissions related to Land Use Change are integrated in the feed emission factors and are coming from Feedprint.

- The tool provides an option to include soil carbon sequestration.

\subsection{Strategic selection and use of monitoring tools}

Many dairy whole-farm tools have been developed and are in use with different purposes (e.g. research, education, monitoring). Most tools have a life cycle approach from cradle-to-farm gate. In this section, it is explained how the tools could be combined or how one overall baseline tool could be used when nothing else is available or to recalculate the GHG emissions in a consistent way.

\subsubsection{Baseline tool}

When no region-specific tool exists, or when farmers are not connected to existing tools, a baseline tool could be used (seems like the Fonterra approach). Another option is that banks could initiate projects with the dairy industry in that specific region to co-develop/support new tools. This baseline tool could for instance also be used to;

- Calculate in a consistent way country-specific science based GHG targets.

- Develop region-specific mitigation strategies.

- Asses the feasibility of certain targets set by regional industries.

The tool doesn't have to be fancy but it needs to be able to assess many different dairy production systems. Important requirements of such a baseline tool are:

- The method and the data implemented in the tool should be adequate to quantify the mechanisms of the mitigation options in scope. This means that a mitigation option with a GHG reduction in practice must also result in lower GHG emissions in the tool.

- The tool shall be based on a consistent secondary and background database for all countries in scope.

- It shall be a whole-dairy-farm tool so interactions between plant production (e.g. grass, maize) and animal production (e.g. calves, milk) can be simulated.

Figure 3.1 shows a simplified overview of such a baseline tool. GLEAM from FAO could, with some adaptations and additions, fulfil the above mentioned requirements.

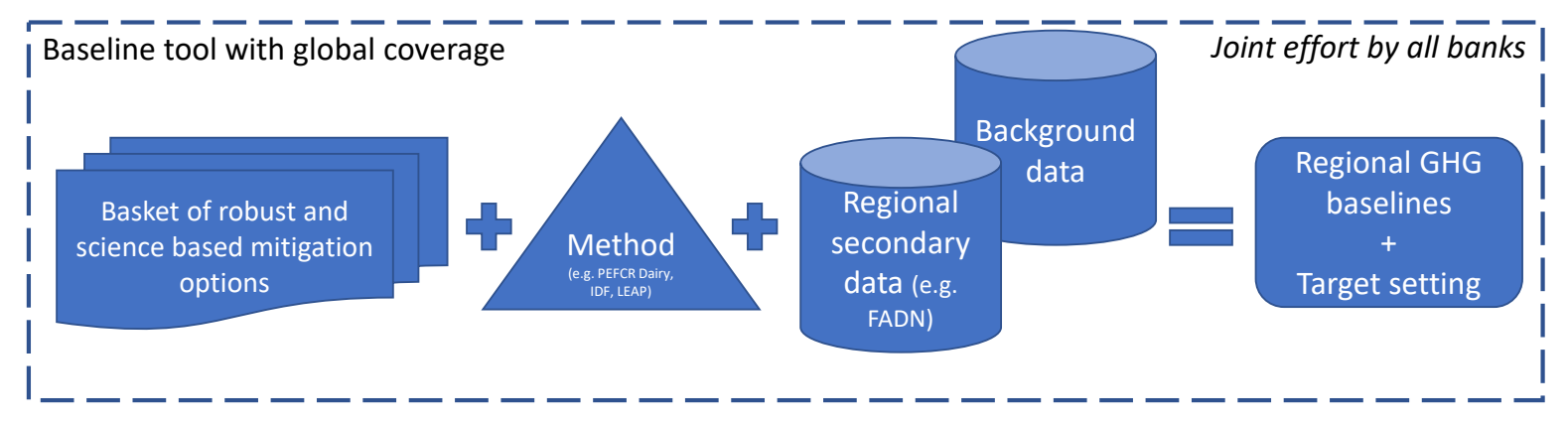

Figure 3.1 Simplified overview of the baseline tool with global coverage 


\subsubsection{Monitoring}

After the targets have been set, they must be monitored. Three monitoring options are explained in this section, including their advantages and disadvantages.

\subsubsection{Full monitoring via existing tools}

The monitoring of the targets is fully based on the already existing regional tools as shown in Figure 3.2.

Advantages:

- No large additional investment needed.

- No inconsistencies in GHG reductions between regional sectors and banks.

- The tools and KPIs are aligned and accepted by the sector and relevant stakeholders. Tools and KPIs are aligned with national targets en monitoring approach.

- GHG tools often build on existing tools for other purposes (e.g. Overseer in New Zealand and Kringloopwijzer in the Netherlands).

- Data collection is already organised or will be organised by stakeholders involved with national tools

\section{Disadvantages}

- Dependency on methodology of regional tools (e.g. desired scope or mitigation options). One of consequences can be unclarity if GHG reductions from mitigation options are correct and in in scope of the initial target setting of the banks (e.g. carbon sequestration sold for carbon credits but also integrated as reduction for the sector - potential double-counting plus method could be based on methodology inconsistent with guidelines).

- A detailed comparison of reductions between several regions is not directly possible because of possible inconsistencies in method and data.

- It could be difficult for the banks to get access to the (regional aggregated) results. It could even be that results are not collected and centrally stored but that the information is in the farmer's computer.

Tool harmonisation can be endeavoured but a full harmonisation will possibly not be achieved. A possible strategy to achieve a certain level of harmonisation is to:

- First be aware of the (major) differences between the most commonly used tools. For most tools information will be available about the alignment with the guidelines as mentioned in Section 2 of this chapter. And obviously it is possible to do a more detailed assessment of the differences.

- Support the harmonisation of the most relevant methodological guidelines to which these tools possibly have to be compliant to from a future legal perspective.

- Support/influence the major tools development path. 


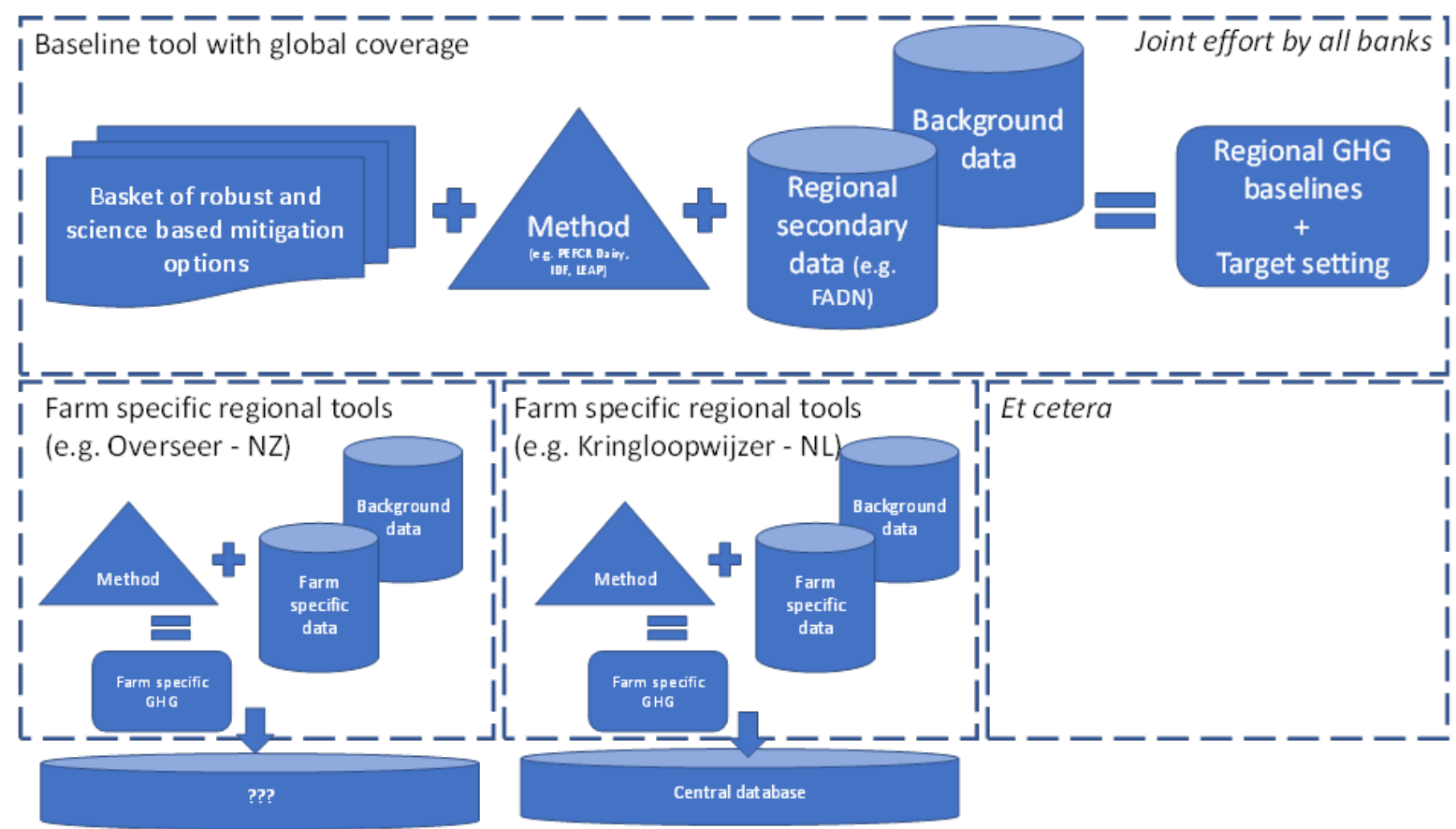

Figure 3.2 Simplified overview of full monitoring via existing tools

\subsubsection{Monitoring based on farm-specific data from existing tools (via interface)}

The farm-specific data is collected from the existing tools and the GHG emissions are recalculated with the baseline tool, as shown in Figure 3.3. Another option is to build a bank-farmer interface to the existing region-specific tools providing more functionalities and interactions between the farmer and the bank. An example of such an interface / interaction is the 'Maatregelentoo/' made by

FrieslandCampina. This way the banks could maybe enable a win-win-win situation (data for insights + convert to consistency + awareness and actions by the farmers).

\section{Advantages:}

- The portfolio level monitoring calculation and method are in line with the original target setting.

- Comparing reductions between several regions is possible.

- The banks are in full charge of their own target/how to assess the GHG emissions.

- Tools and KPIs as used by the farmer are aligned and accepted by the sector and relevant stakeholders.

\section{Disadvantages}

- Reductions calculated by the banks could be different compared to reductions communicated by dairy sectors.

- There might still be an harmonisation issue because local tools might use a different methodology and therefor different input data, so additional input data might be required.

- It would be quite an effort to acquire the original input data from the local tool and possibly additional data to recalculate the GHG emissions. It is to be expected that input data is not collected and stored centrally. 


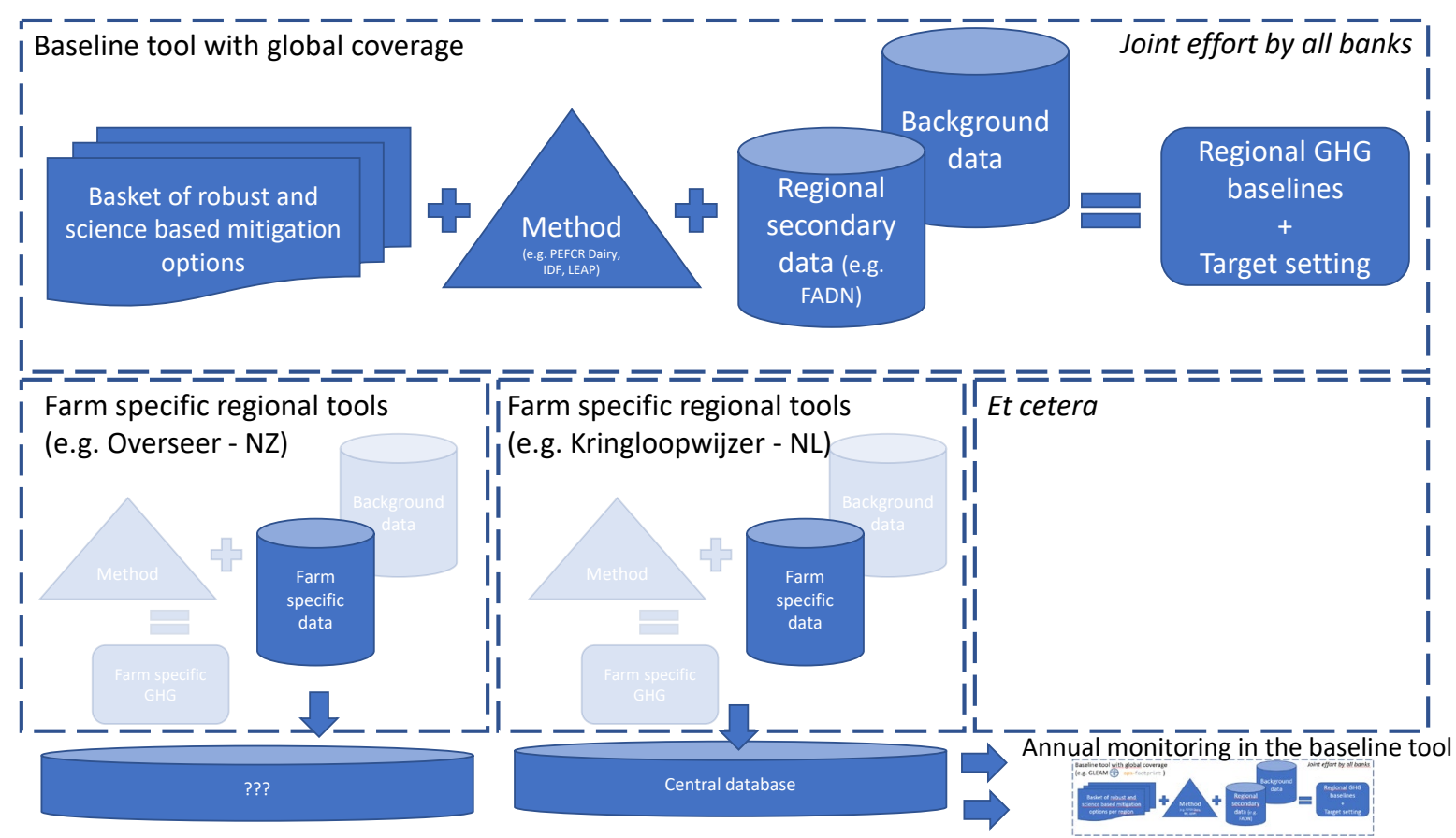

Figure 3.3 Simplified overview of collecting farm-specific data from existing tools and recalculation with the baseline tool

\subsubsection{Monitoring based on the penetration rates of the mitigation options}

When the regional penetration rates for each mitigation option are monitored on a country level, the annual GHG reduction is the sum of all the penetration percentages multiplied by the reduction percentages (see Figure 3.4). It shall be monitored that the reduction potential per mitigation option is also reached in practice via for instance case-studies.

\section{Advantages:}

- The monitoring calculation and method is in line with the original target setting.

- Comparing reductions between several regions is possible.

\section{Disadvantages:}

- A monitoring system for mitigation options needs to be developed.

- The sum of applied mitigation options could be less because mitigations options could negatively influence each other.

- Reductions calculated by the banks could be different compared to reductions communicated by dairy sectors.

- This approach can be used on a country level and not on a farmer level. So specific advice to farmers from the banks will not be possible with this approach. 


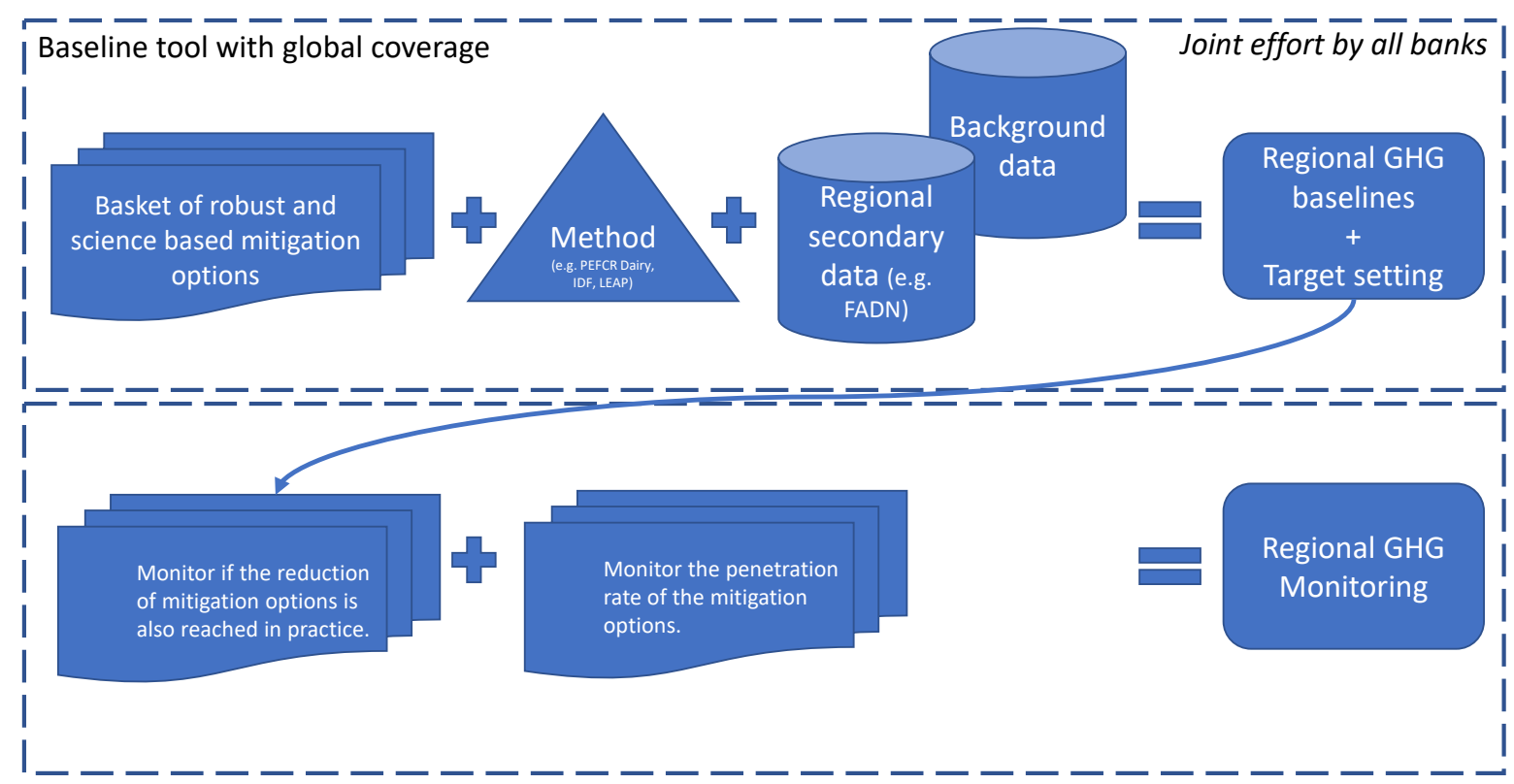

Figure 3.4 Simplified overview of monitoring based on the penetration rates of the mitigation options

\subsection{Observations and considerations}

The following observations and considerations can be drawn:

Use of GHG tools by dairy farmers. GHG tools are available for all dairy farms in the Netherlands, will become available on all farms shortly in New Zealand and is starting up in Australia and the USA. It is expected that the use of these tools will increase significantly driven by processing company targets and multiple monitoring systems (within and between countries).

GHG monitoring should ideally be connected to existing databases. This can be national databases, farm management systems or accountancy data. This is important in order to to lower administrative burden for farmers, to improve quality of data, to improve consistency with other farm management data. The use of existing data might be a trade off with international harmonisation.

Use of existing and accepted national tools has some main advantages. The most important advantages being: no extra effort required from farmers or banks in data collection and national alignment between all stakeholders in the use of GHG numbers. The main disadvantage is that GHG data can differ between countries, so it is more complicated to monitor the development in GHG emission over de international portfolio of the bank.

A (non-fancy) internal baseline tool (e.g. GLEAM) could be helpful for regions without country-specific tools. To at least get an overview of the national level data from Farm Accountancy Data Networks (FADN) or data from client sampling could be used. This approach is obviously not sufficient for advice en monitoring for individual clients. It is also possible to obtain data from the farmer on which he will receive his footprint (Fonterra approach). For a detailed calculation which also can be used to advise on mitigation options the farmer has to supply good quality and quite detailed data.

The choice of the most appropriate approach depends mostly on what is considered as most important. If an accurate assessment of the current baseline and the progress of the development of the emission of the portfolio of the bank is seen as critical than the use of a baseline tool for the whole portfolio of the bank could be considered. If creating progress and offering advice on farm level is considered as most important that alignment with national tools and progress is more appropriate. 


\subsection{Possible follow-up steps}

The following follow-up steps could possibly be performed:

- Session with the banks to set more detailed requirements so a preferred approach can be investigated in more detail.

- To explore the possibilities to start building a database or expand the current financial database, with the most relevant parameters from dairy farmers in the portfolio:

- via data exports from the tools (not only the GHG results).

- by connecting to accountancy networks.

- via data collection.

- Two region-specific in-depth case studies:

- Region with existing tool to investigate:

- the willingness of the tool developers and/or the stakeholders that work on national sector GHG programmes to work together with banks.

- ways to obtain the data/results from farmers.

- in more detail if the developer/tool:

- is capable to upscale to full-industry level.

- is capable to cover the mechanism of the science-based mitigation options selected by the banks (so the GHG reductions are visible in the results when applied).

- is approximately aligned with the most relevant methodological guidelines (e.g. IDF, PEF dairy, et cetera).

- is willing to implement methodological/functional modifications or to connect to a future bank interface.

- Region(s) without existing tool:

- Investigate if relevant stakeholders have interest in co-developing, or support, the development of a tool.

- Investigate available data sources (e.g. FADN, sampling) and assess the GHG emissions by using the baseline tool.

- Investigation if GLEAM could be used as internal baseline tool and which adaptations are needed to reach the requirements set by the banks. 


\section{$4 \quad$ Mitigation options}

\subsection{Introduction}

Livestock production plays an important role in the climate change by emitting GHG either directly (from enteric fermentation and manure management) or indirectly (from feed production and conversion of forest into pasture).

To define the mitigation strategies in the livestock production firstly it is important to identify the main sources of emissions.

- Animal production; where enteric fermentation is the main source of GHG emissions in this category.

- Animal management, which deals with animal productivity, health and lifespan.

- Feed production, in which different sources of GHG emissions such as fossil fuels, chemical fertilisers, biocides, agricultural operations, feed processing and other inputs are applied.

- Land use and land-use change, is including the change of natural vegetation to pasture or arable lands. Note that this category can be added up to the feed production category.

- Manure management, which is mainly related to manure storage, application and deposition activities.

Based on the FAO data, in dairy systems, feed production process contributes around $45 \%$ of livestock emissions and after that enteric fermentation accounts for $39 \%$ and followed by manure storage (10\%) and processing and transportation (6\%) (Gerber et al., 2013; Grossi et al., 2019). Since in this chapter we consider the mitigation options until the farm gate, where livestock products leave the farm, processing and international transport is out of the scope. The share of different sources of GHG emissions on total emissions is highly variable among the production systems and regions. In low input smallholder systems, feed related emissions are a smaller fraction and methane from enteric fermentation is a larger fraction. Also the fraction of $\mathrm{CO}_{2}$ emissions from fossil fuels is smaller compared to specialised and high productive dairy system (Gerber et al., 2011). As it is shown in Figure 4.1, the share of $\mathrm{CO}_{2}$ in total GHG emissions of dairy farming increases while the share of $\mathrm{CH}_{4}$ and $\mathrm{N}_{2} \mathrm{O}$ decrease with the productivity gains. The higher $\mathrm{CO}_{2}$ emissions is due to the higher consumption of fossil fuel for production of feed. An intensive production system requires a variety of inputs which directly or indirectly use fossil fuels. These include the production of feeds (land preparation, harvesting, use of fertilisers and pesticides, drying, etc.), transport, storage, processing and etc. 


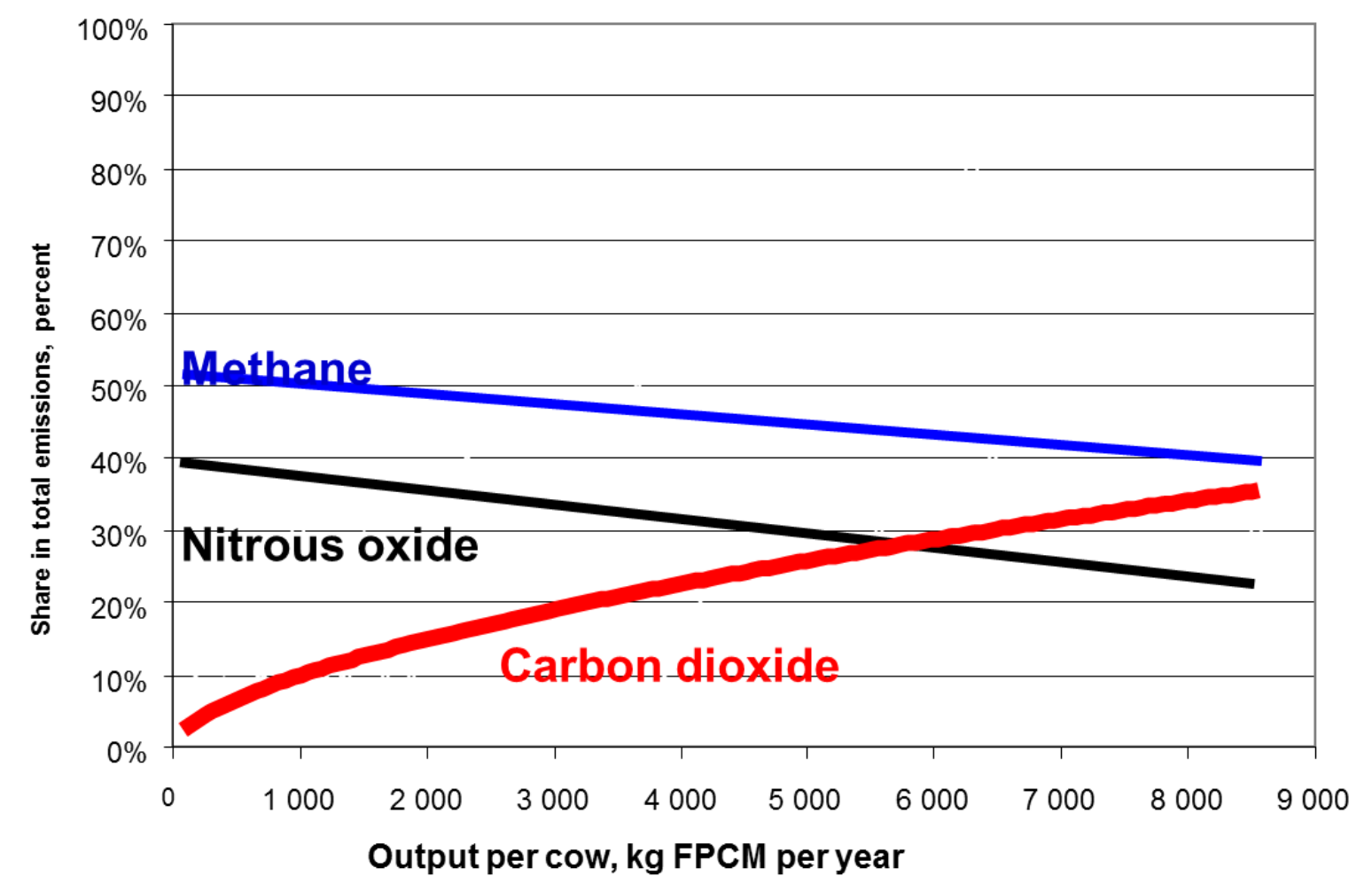

Figure 4.1 Relationship between carbon dioxide, methane and nitrous oxide emissions and output per cow (productivity) in dairy farming systems

Source: Gerber et al. (2011)

GHG emissions regarding the enteric fermentation and manure storage varies among the livestock species. Figure 4.2 which has been adapted from Global Livestock Environmental Assessment Model (GLEAM) developed by FAO (FAO, 2017) shows the GHG emissions associated with the enteric fermentation and manure storage for different animal types. As it is shown, enteric fermentation is the main source of GHG emissions in ruminant animals. Also beef and dairy are the greatest contributors to the climate change among various species. 


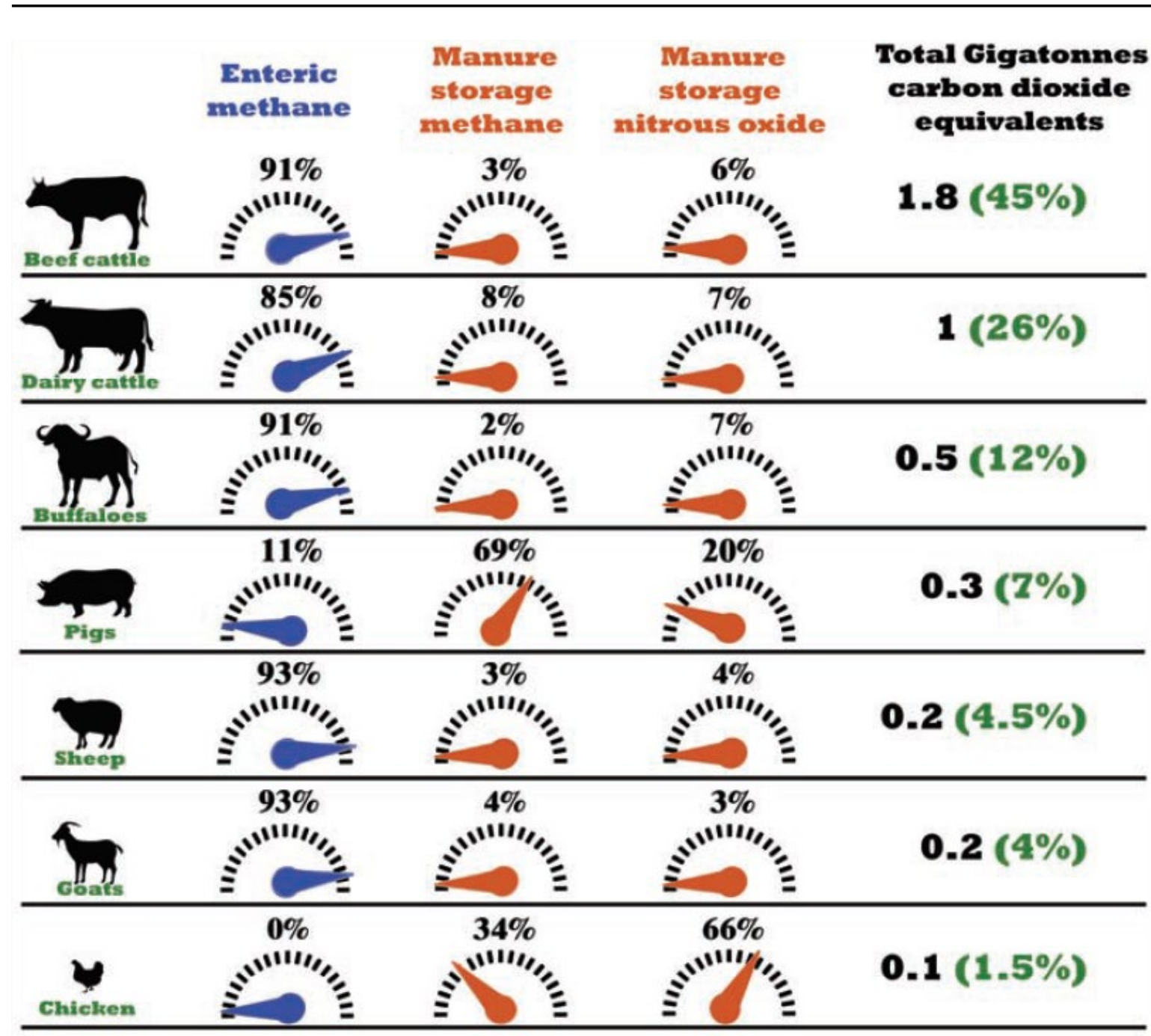

Figure 4.2 GHG emissions associated with the enteric fermentation and manure storage for different animal type

Source: Grossi et al. (2019).

After highlighting the main sources of GHG emissions in the livestock production system, the next step is defining the mitigation strategies. The most important GHG mitigation strategies and mitigation potentials are presented as follows:

\subsection{Animal production (enteric fermentation)}

Enteric fermentation is a natural part of the digestive process that takes place in ruminant animals by which carbohydrates are broken down into soluble products. Methane $\left(\mathrm{CH}_{4}\right)$ is produced when enteric fermentation occurs in the rumen. Depending on the feed intake and its digestibility, enteric methane rate varies. Mitigation strategies for this source of emissions focus on increasing the productivity and decreasing the rumen fermentation. Some of the strategies are mentioned hereafter.

\section{Improving forage quality by earlier harvest}

Forage quality and the harvesting time are the main players in enteric fermentation. Digestibility decreases during the forage growth and by early harvesting the methane emission may be reduce up to $5 \%$ per fat protein corrected milk (FPCM) (Knapp et al., 2014). Feeding grass silage at an early growth stage can reduce the total enteric methane production of lactating dairy cows around $11 \%$ where this reduction is equal to $22 \%$ per kg FPCM (Warner et al., 2017). Additional, unpublished research, however, shows that this gain can be counteracted by the higher emission intensity of the feed production (Vellinga et al., 2021, in prep). 


\section{Improving forage digestibility by forage processing}

According to the previous studies, forage mechanical processing operations including chopping, grinding, and steam treatment can improve the digestibility of feed which leads to less enteric fermentation (Gerber et al., 2013). Steam flaking is the widely applied method in the US however, the high operation costs limit the mitigation potential in small scale farms (Ahmed et al., 2020). The GHG mitigation potential has been reported to be less than 2\% per FPCM (Knapp et al., 2014). Results of another study showed that applying feed processing decreases the methane production by around $15 \%$ per animal (Ahmed et al., 2020).

\section{Increasing concentrate inclusion in the feed ration}

One of the options to improve the animal feed ration is increasing the share of concentrate. Generally, concentrate provides more digestible nutrients (per unit feed) than roughage. It should be noted that this depends on the productivity level. According to Knapp et al. (2014) study this strategy can decrease the methane emission between 15\% per kg FPCM. This improvement can be beyond 35 to $40 \%$ of total enteric fermentation but it also depend on the feed intake amount and emissions associated with the production of concentrates (Gerber et al., 2013).

\section{Diet composition}

One of the long-term strategies for GHG mitigation options is replacing the grass silage with maize silage in the feed to reduce the enteric fermentation. This strategy not only affects the enteric fermentation but also has impact on other sources of GHG emissions at farm level and through the whole supply chain. According to the results obtained by Van Middelaar et al. (2013), it was revealed that this strategy can reduce the annual emissions by $12.8 \mathrm{~kg} \mathrm{CO} 2$ eq per tonne of FPCM. However, changing the grass land to maize land results in emitting $913 \mathrm{~kg} \mathrm{CO} 2$ eq per tonne of FPCM due to the land use change. Therefore, it takes 44 years that the annual emission reduction pays off the emissions due to land use change.

It should be noted that too high protein contents in the feed can cause toxic effects in different parts of the animal body such as uterus.

\section{Feed additives and supplements}

There are various feed additives and supplements which affect the GHG emissions of enteric fermentation. In next section some of the important additives and their impact as a GHG mitigation strategy will be discussed.

\section{- Fatty acids addition}

Addition of fatty acids to the ruminants diets is widely applicable and recognised as effective in decreasing the enteric fermentation. Various feed ingredients such as cottonseed, brewer's grains and cold-pressed canola meal can decrease the methane production. According to Knapp et al. (2014) study the highest GHG reduction was reported when $5-8 \%$ of diet (dry matter) was consisted of fatty acids. The enteric methane reduction potential was $15 \%$ per fat protein corrected milk. MacLeod et al. (2015) research indicated that every 1 additional kg dry matter provided by fatty acids leads to $4 \%$ methane reduction. It should be considered that due to health issues, the fatty acid contents should not exceed $6 \%$ of feed dry matter (MacLeod et al., 2015). Also, too high fatty acid contents will lead to low quality pellets.

\section{- Feed additives}

Feed additives such as electron receptors (e.g. fumarate, nitrates, sulphates and nitroethane), ionophoric antibiotics, chemical inhibitors (such as 3-Nitrooxypropanol (3-NOP)) have shown a positive impact to reduce methane emissions (Beauchemin et al., 2009). For example, among additives promising results have been reported for nitrate which in some cases has reduced $\mathrm{CH} 4$ emissions by 30 to $60 \%$ (Jayasundara et al., 2016). Although the impacts of feed additives on reduction of enteric fermentation was observed, the health risks associated with using this additives should be considered (Herrero et al., 2016).

Other additives which have recently received attention as GHG mitigation agents such as Ionophores (e.g. monensin), plant bioactive compounds (e.g. tannins and saponins) and etc. (Russell and 
Houlihan, 2003; Beauchemin et al., 2007; Gutierrez-Bañuelos et al., 2007; Brown et al., 2011). The results showed that electron receptors can decrease the GHG emissions by up to 50\% (Gerber et al., 2013). The reduction potential between 7.5 to $15 \%$ was reported for Ionophores (Grossi et al., 2019). Lipid supplements have also been indicated for 9 to $12 \%$ reduction however, this additive may have negative interaction when used in warmer climate in terms of higher $\mathrm{CH} 4$ emissions (Hellwing et al., 2014).

Since using high levels of feed additives specially the use of antibiotics leads to anti-microbial resistance, new regulations are released to prohibit the use of the feed additives. For example, based on the EU regulations four feed additives namely monensin sodium, salinomycin sodium, avilamycin, and flavophospholipol are not allowed to be used in livestock production in EU (EC, 2002).

\section{Application of Seaweed}

Recently focus on using seaweed as a feed ingredient has grown where it can improve not only the livestock productivity (growth, lactation, gestation) but also the enteric fermentation. Many research have been conducted to determine the GHG reduction potential as a result of using seaweed in feed. Li et al. (2018) reported a reduction of $80 \% \mathrm{CH}_{4}$ production in sheep while for lactating dairy cattle the reduction was reported up to $67 \%$ (Roque et al., 2019). According to the results obtained by Kinley et al. (2020), using $0.10 \%$ and $0.20 \%$ seaweed (Asparagopsis) as a feed ingredient can decrease the methane production up to $40 \%$ and $98 \%$, and also can improve the weight gain by $53 \%$ and $42 \%$, respectively. Bromoform is the active ingredient of the seaweed, which is volatile and negatively affecting the ozone layer. Effects of its application on animal health are yet unknown. It is recommended to be very careful with halogen containing materials. Although some researchers found promising results for this technique, however there many questions and debates about the negative impact of applying this technique on the livestock production system as a GHG mitigation option. First results of a practical in vivo trial ${ }^{26}$ with cows showed however no or low potential

\subsection{Animal management}

In this section the mitigation options which deals with animal management agents such as animal productivity, breeding, health and lifespan are addressed.

\section{Animal productivity (milk yield/cow)}

Increasing animal productivity by improving the genetic potential of livestock, their reproductive performance, health and liveweight gain is among the most effective GHG mitigation strategy in most of the countries (Gerber et al., 2013; Herrero et al., 2016). Genetic changes can improve the feed efficiency and subsequently reduces the GHG emissions. Also, increasing the productivity leads to reduction in numbers of animals needed to produce the same amount of milk and subsequently a lower environmental footprint. For example, based on the annual statistic report for the milk production in Netherlands, during the last 38 years (from 1980 to 2018) the average milk production per lactation of the milk recorded cows increased from 5,500 to 9,900 kg which shows the substantial impact of genetic improvement and other strategies for increasing the productivity (CRV, 2020).

\section{Breeding for reduced methane}

Improving the genetic potential of livestock, has indirectly positive impact on reduction of GHG emissions per unit of livestock product. Based on the finding of the previous research (De Haas et al., 2011; Mollenhorst and de Haas, 2019), there is great potential in adopting genetic and genomic selection strategies to tackle methane emissions from ruminants (Lesschen et al., 2020b). It is claimed that $20 \%$ of methane emissions can be decreased by genetic modifications (Bell et al., 2010; Harmsen, 2019; Ahmed et al., 2020). New modified genetic breeds in US have 5\% less GHG emissions per animal and applying these breeds without any change in productivity would lead to a reduction of the GHG emissions from 53 to $42 \mathrm{~kg} \mathrm{CH}_{4}$ per animal (Ahmed et al., 2020). Based on the

\footnotetext{
26 https://www.wur.nl/nl/Onderzoek-Resultaten/Onderzoeksinstituten/livestock-research/show-wlr/Voorlopig-beeld-uitproject-Zeewier-in-een-gezonde-melkveehouderij.htm
} 
Beukes et al. (2010) findings it is possible and feasible to decrease the methane emissions by at least $10-20 \%$ by genetic selection.

\section{Animal health}

By improving the animal health, the animal mortality rate decreases and the productivity increases. Herd management and applying new monitoring tools help to check the animal condition continuously. Mostert et al. (2018a) studied the impact of monitoring the animal health on GHG emissions of milk production and found that preventing the subclinical ketosis (SCK) reduces the total emissions by 20.9 $\mathrm{kg} \mathrm{CO} 2$ eq per $\mathrm{kg}$ FPCM (equal to $2 \%$ GHG reduction per $\mathrm{kg}$ FPCM). In similar studies it was found that it is possible to reduce $6.2 \%$ and $1.5 \%$ of total GHG emission per kg FCPM by preventing the clinical mastitis and foot lesions in dairy cows, respectively (Mostert et al., 2018b; Mostert et al., 2019). In North America $8 \%$ GHG reduction potential was reported by applying animal health management methods (Ahmed et al., 2020). Innovation in the animal health products could increase the availability of vaccines for emerging diseases such as African swine fever (Gerber et al., 2013).

\section{Life span or replacement rate}

Changing the productive life span per animal is a management parameter which affects the milk production and indirectly has an impact on total GHG emissions per product. Changing the productive life span in a herd is done by changing the replacement rate. This can be management intensive and it requires a proper health management. The productive life span after first calving on most farms ranges from 2 to 6 years. Results of Vellinga and De Vries (2018) research showed that increasing life span (or decreasing the replacement rate in herd) from 2 to 6 years reduces the GHG emissions between 14-19\% per kg FPCM.

\subsection{Feed production}

As it has been discussed, feed production is one of the main sources of GHG emissions in livestock production. Chemical fertilisers as the main source of soil nitrous oxide emissions play an important role in identifying the GHG mitigation strategies for crop production. Therefore, most of mitigation strategies in feed production are around the mitigation of nitrous oxide emissions. Due to the fact that the main focus of this study is on livestock production, some of the most important strategies are presented and described.

\section{Low or no tillage practices}

Low and no tillage practices in crop and fodder crop production reduces the soil organic matter loss, soil erosion, and water loss. Also, less tillage decreases the emissions associated with the fuel consumption. This reduction can be around 75\% of on farm fuel usage (Van Kessel et al., 2013). Another advantage of applying low or no tillage practices in a combination with deep placement of nitrogen is the reduction of denitrification in soil. These practices reduce nitrous oxide emissions around $18 \%$ per $\mathrm{kg}$ crop (Van Kessel et al., 2013). Although positive impact of low or no tillage practices on reduction of GHG emissions has been revealed, the possibility for the temporary reduction of crop yield (which has been reported by Seddaiu et al. (2016); Król-Badziak et al. (2021)) and weed control difficulties should be considered as a limiting factor for developing the use of these practices widely.

\section{Reduction of nitrogen application and use of clover}

In most of developing countries and also in China and India, a high level of chemical fertilisers application in crop production is seen which leads to a great amount of nitrous oxide entering the atmosphere by evaporation. To stop this situation, it is essential that all countries correct the overapplication of nitrogen fertilisers to the standard levels. It is asserted that this strategy will lead to approximately $24 \%$ reduction in global GHG emissions (Ahmed et al., 2020). Replacement of nitrogen fertiliser by the organic fertiliser such as legumes is a strategy for $\mathrm{N}_{2} \mathrm{O}$ mitigation in managed grasslands. Fuchs et al. (2018) studied the impact of this strategy and found a $33 \%$ reduction on $\mathrm{kg}$ $\mathrm{N}_{2} \mathrm{O}-\mathrm{N}$ per kg grass dry matter by increasing the clover proportion in grassland and reducing fertilisation. 


\section{Grazing management}

Grazing management consists of various strategies which helps pasture to keep the highest productivity level and less GHG emissions. Intensive rotational grazing systems have been introduced and widely recommended to increase the forage production and to reduce the nitrous oxide emissions (Grossi et al., 2019). Many research has confirmed that rotational grazing systems provide higher levels of yield compared to the continuous grazing (Chen and Shi, 2018). In these systems, farms or pastures are divided to smaller fields which are called paddocks. Subdividing farms to paddocks and rotating animals in the paddock helps the farmer to have more control on the grazing duration, stocking density and nitrogen excreta distribution (Grossi et al., 2019). Besides the impact of grazing management strategies on grass yield, it also affects manure management on pastures. Therefore, the GHG emissions of manure deposition during the grazing decreases. A more balanced distribution of animal urine in the pasture may reduce the nitrogen fertiliser application rate. Also keeping animals off the paddocks during wet weather will reduce the soil compaction (Grossi et al., 2019).

\section{Carbon sequestration}

Carbon sequestration can be considered as an important mitigating option in the grassland soil. Carbon sequestration is the process in which the carbon from atmosphere is converted via photosynthesis to stable biomass, stored in the soil or (long term) above ground biomass. Therefore, it can be considered as a GHG mitigation option for the livestock sector. Based on the study that was conducted by Salvador et al. (2017), grasslands can have a high impact on reduction of GHG emissions by carbon sequestration and the average reduction of $28 \%$ GHG emissions per $\mathrm{kg}$ FPCM was estimated for dairy farms. This high impact can only be realised with young pastures on previous arable land and should be considered as a theoretical maximum level and probably low milk yields per hectare. In temperate climates the maximum sequestration rate is calculated at about 3.5 to 4.5 tonnes of $\mathrm{CO}_{2}$ per hectare per year. This very high figure which cannot be realised in permanent grassland areas. Older pastures have reached an organic matter equilibrium and sequestration levels off. The main goal of grassland management is to prevent loss of the high equilibrium levels. Results of Lesschen et al. (2020b) study showed that carbon sequestration reduced the carbon footprint of milk by $2 \%$ in the case of permanent pastures with a milk production of about $15,000 \mathrm{~kg}$ of milk per hectare. This is a sequestration rate of about $300 \mathrm{~kg} \mathrm{CO} 2$ eq per hectare per year. To increase the carbon sequestration or to maintain current high levels of carbon stocks, land use changes (e.g. deforestation, change of grasslands to croplands) and ploughing up long-term grasslands should be avoided.

In addition, it should be considered that carbon sequestration requires additional nitrogen, due to the $\mathrm{C}$ to $\mathrm{N}$ ratio of $10-15$ to 1 , which means that for every $1,000 \mathrm{~kg} \mathrm{CO} 2$ sequestered, 18 to $27 \mathrm{~kg} \mathrm{~N}$ surplus is required. Although carbon sequestration has a certain potential, especially in degraded soils, expectations have to be managed to moderate levels.

Afforestation and deforestation are among the main strategies to increase the capacity of carbon removal. This strategy can be considered as an option for dairy production system however, it is recommended to be applied on waste lands not on pastures.

\subsection{Manure management}

\subsubsection{Introduction}

Manure entails the whole chain between excretion, via storage and transport to application in the field. It is a source of both methane and nitrous oxide and depending on the composition of dung and urine, the collection and storage, the application in the field, in relation with environmental conditions. Under anaerobic conditions bacteria decompose the organic matter and produce methane and nitrous oxide. Some of the important methane mitigation strategies for manure management are: separate collection of dung and urine, covering the outdoor slurry storage, shortening the indoor storage time, frequent and complete removal of the slurry from the building, lowering the slurry temperature, filtration of the air from the livestock house and storage facility, aeration, acidification, feed adjustments and controlled anaerobic digestion. 
The composition of dung and urine is directly related to the feed intake and animal performance; however the impact of the feed ration on emissions is still not fully understood. Currently the animal requirements, health and costs of feed as well as the rumen methane and GHG emissions of feed production are the determining factors of the optimal ration in terms of their impact on environment. The matter is to come with a holistic approach where emissions from feed production, feed consumption and manure management are evaluated together.

Mitigation options associated with manure management can be grouped into the following interventions:

1. In-barn interventions

2. Intermediate interventions

3. Application interventions

In-barn interventions can be classified into following measures:

- Floor based systems and related management techniques (including primary separation of dun and urine, floor type, manure collection such as scrapers and cleaning robots, etc.);

- Litter based systems (use of alternative organic material);

- End-of-pipe techniques (air scrubber, hybrid ventilation + air cleaning techniques).

Intermediate interventions covering slurry treatment techniques can be classified into following measures:

- Storage based strategies (retention time, temperature at storage tanks, inoculum removal, flaring methane, acidification, etc.)

- Slurry separation

- Anaerobic digestion

Application intervention can be categorised as follows:

- Application methods and conditions

- Inhibitors for manure application

One of the limitations of innovative technologies to mitigate GHG emissions is that farmers are not paid off for implementation of mitigation measures such as low-emission houses; In such cases farmers may invest on technical changes but maintaining the installations as it should be has no priority; therefore, enforcement guarantee is dramatically important.

\subsubsection{In-barn techniques}

Slatted floors and solid floor both can be adapted to these techniques. This is not only the floor type which mitigate emissions but also, scrapers and cleaning robots play an important role. How effectively these tools work can affect the emission rate. Spraying the floor to dilute and remove the urine puddles are the other options. This system can also be combined with urease inhibitors to reduce ammonia emission from the urine. The emission reducing effect of these systems is highly dependent on the maintenance of the system. For example if the floor slats clog with manure this limit the efficiency of the system in reducing emissions. In practice, using scraper and robots may perform best in the newly-built barns where the equipment can be integrated with the floor layout.

A recent research has shown the effect of floor/housing type (Jayasundara et al., 2016). The $\mathrm{NH}_{3}$ emissions from tied housing systems are significantly lower than those from loose housing systems with cubicles, for example - and within the 'loose housing systems with cubicles' category, no significant differences can be detected between the 'perforated' and 'solid' floor types for either $\mathrm{NH}_{3}$ or $\mathrm{CH}_{4}$ emissions. This is explained by the separate collection of dung and urine in tied housing systems, while cubicle systems often work with slurry, being a mixture of dung and urine. Within cubicle systems, a reliable technique to abate $\mathrm{NH}_{3}$ emissions is 'grooved floor' system for dairy and beef cattle housing, employing 'toothed' scrapers running over a grooved floor. The grooves equipped with perforations allow the urine to drain so that the surface will be cleaner and therefore emissions will 
reduce from $25 \%$ to $46 \%$ relative to the reference system (Swierstra et al., 2001). In fact this is based on the timely separation of dung and urine.

\section{Primary separation}

Separation of urine and faeces and limiting the air exchange with separate storage for both components is the basis of the low-emission floor types. The theme of 'separation at the source' has received attention in the research world for years. Primary manure separation (keeping faeces and urine separated as much as possible) in the barns has potential advantages: the ammonia emission is greatly limited and the individual manure products can be better processed or used more specifically, more biogas can be extracted from fresh manure, there is less methane emission from the barn (no more deep manure storage).

In principal, the physical separation of faeces and urine in the housing system reduces the hydrolysis of urea (cow urine contains nitrogen in the form of urea), resulting in reduced emissions from both housing and further manure spreading (Moller et al., 2007). The potential of the separation of dung and urine collection and storage have been discussed by Lesschen et al. (2020a), leading to significant emission reductions of $75 \%$ for methane and ammonia.

In the Netherlands, a toilet especially for cows is being developed to separate dung and urine. Such a toilet would prevent urine to come on the floor and tackle the problem of ammonia emissions in dairy farming. Research at Wageningen Livestock Research (WUR) has shown that if $80 \%$ of the urine discharges per day could be collected and therefore do not end up on the barn floor, the expected emission reduction in a conventional free stall barn with slatted floor is approximately $56 \%$ (Verdoes and Bokma, 2017).

\section{Reduction storage time}

There is always a trade-off between the optimal moment of slurry application on pasture and cropland and storage duration. Farmers are increasingly recommended to store the manure for extended periods to recycle manure nutrients to crops in spring (Oenema et al., 2011). Unfortunately, this increases the potential for $\mathrm{CH}_{4}$ emissions during storage. Therefore, in-barn and outside storages facilities should both be traced separately and with high spatial and temporal resolution while measures can alleviate the unavoidable emissions.

Methane emissions from slurry pits can be significant due to continuous inputs of fresh excreta and often higher temperatures than in outside storages, but these emissions are difficult to quantify because of enteric emissions from the housed animals, which may vary with time of day and stage of a production cycle. Therefore, reducing the storage time by frequent removal of manure helps to reduce the GHG emissions by around 50\% (Mohankumar Sajeev et al., 2018) and in some cases reported as $66 \%$ (Hilhorst et al., 2002). Designing stables with underfloor channel (combined with scraper) helps to remove the manure easier. In addition, measurements showed a reduction of more than $50 \%$ of methane emissions for well covered outdoor storages (Hilhorst et al., 2002).

If manure storage no longer needs to be done in the barn (due to the rapid removal), the methane emissions will decrease by about $25 \%$. The costs for this method of manure removal will of course increase, but savings are also possible at the floors and manure cellars. Although application of manure on crop farms reduces the storage time it has to be matched with the growth potential of crops. In temperate regions where crop in winter periods is very low, manure application in winter will lead to high losses of $\mathrm{N}$ and contamination of ground and surface waters.

\section{Reduction of storage temperature}

Methane production increases by increasing the storage temperature. In lower temperature, methanogenic activity stops. Thereby many research is ongoing to observe the effect of cooling manure in the barn or in outdoor storages during summer. A reduction of $30-50 \%$ of emissions was reported by a reduction of storage temperature (Borhan et al., 2012). However, the energy consumption should be considered when this strategy is being applied. 


\section{Acidification in manure storage}

Little is known about the impact of acidification of manure in manure pits or storage. Acidification is done to bind nitrogen and hence prevent ammonia emission. Slurry, however, is a strong buffer and relatively large amounts of acids are required. Moreover, when acidifying, $\mathrm{CO}_{2}$ gas which exists in manure, flows out. Acidifying the slurry during storage, reduces both ammonia and methane formation. Environmental issues to be considered with this technology are changes in the odour profile, and field application of sulphur in excess of crop needs, because 5 to $6 \mathrm{~kg}$ per tonne of $\mathrm{H}_{2} \mathrm{SO}_{4}$ is needed for acidification of cattle slurry (Groenestein et al., 2011).

\section{Manure aeration}

In dairy farms equipped with a slatted floor above a deep manure pit, the remaining manure forms a basis for methane formation. In this situation, methane and ammonia are released. Frequent mixing of manure can possibly influence the formation of these gases. Low rate slurry aeration causes a reduction in chemical reaction and prevent crust formation in the slurry pit. This method is now tested in the Netherlands. An study by (van Dooren et al., 2019a) showed that daily mixing of slurry either with air pumped into the slurry or with an electrical mixer did not result in reduction of ammonia emission. However, Calvet et al. (2017) explained a reduction in the emission of $\mathrm{CH}_{4}$ by $40 \%$.

\section{Litter-based systems}

These systems are more common in beef cattle farming where straw is utilised as bedding. In this method, the ammonia emissions can be reduced by using organic substances because the $\mathrm{pH}$ is lower, bacteria uptake is higher and higher amount of ammonia can be absorbed. The risk of forming nitrous oxide in litter-based systems should be considered. With bedded pack barns nitrous oxide emissions were measured to be 3 to 26 times higher than the reference system (a concrete slatted floor with slurry storage in a pit underneath the floor) (van Dooren et al., 2016). The research was done in WUR showed that wood chips for composting are better than composted manure in terms of animal welfare and emissions from the barn. However, emission of $\mathrm{N}_{2} \mathrm{O}$ from bedded pack barns was higher compared to free stall barns (Van Dooren et al., 2019b). Ammonia emission was reduced by $31 \%$ but methane emission increased by $34 \%$ and emissions of nitrous oxide were 14 times higher than a reference slurry-based housing system (van Dooren et al., 2019a; Van Dooren et al., 2019b).

\section{Air scrubber}

Air filters, which are still under development, can result in a reduction of up to $50 \%$ of the total methane emissions from livestock (Hilhorst et al., 2002). Air scrubbers work best in closed houses since they require mechanical ventilation of the house, while most of the dairy livestock houses are naturally ventilated. Acid scrubbers and biotrickling filters have been developed for ammonia $\left(\mathrm{NH}_{3}\right)$ removal at pig and poultry houses in the Netherlands over the last 20 years to prevent ammonia emissions and consequently acidification and eutrophication of soils. Reducing ammonia emissions works indirectly as a GHG emission mitigation option because the more $\mathrm{N}$ in manure remains, the less fertiliser is required when land applied. There are several air scrubbers on the market. $\mathrm{The}^{\mathrm{NH}_{3}}$ removal of acid scrubbers ranged from $40 \%$ to $100 \%$ with an overall average of $96 \%$. The $\mathrm{NH}_{3}$ removal of biotrickling filters ranged from $-8 \%$ to $+100 \%$ with an overall average of $70 \%$ (Melse and Ogink, 2005).

Air scrubbers were compared by using life cycle assessment and assessing five environmental impacts: climate change, terrestrial acidification, marine eutrophication, particulate matter formation and fossil fuel depletion. The acid scrubber showed reductions in all environmental impact categories whereas the biotrickling filter with combined nitrification and denitrification had highest climate change and fossil fuel depletion (De Vries and Melse, 2017).

Air scrubbers are mainly applied in pig and poultry barns. Despite the impacts of this strategy on GHG reduction, the use of the installation requires a lot of energy and farmers are hesitant to use the equipment. 


\section{Combining different housing techniques}

Most of the discussed options can reduce different range of emissions. Combining these techniques may improve the mitigation efficiency; for example, by combining floor cleaning and primary separation. However, it should be considered that some techniques may not be compatible when applied together. Combining ventilation with end-of-pipe treatment of the exhaust air is a state-of-the art technique. In this method, the air in slurry canals and manure storage are both cleaned before leaving the barn.

Decrease temperature and reduce air velocities by optimal barn climatisation with roof insulation can achieve a moderate emission reduction. New designs should combine emission reduction from the floor (increased run-off of urine) and from the pit (reduction of air exchange by rubber flaps in the floor slots).

Reducing air temperature and the air velocity by using optimal indoor climate conditions with roof insulation and automatically natural ventilation can reduce emissions moderately (20\%) (Monteny, 2000).

\subsubsection{Intermediate techniques}

\section{Secondary separation}

Solid-liquid separation is a common method to decrease the methane production during the storage time. This process is done using different techniques such mechanical separation (centrifuge systems, belt press, etc.) and filters. Based on the previous research, more than $30 \%$ of emissions decreases by applying solid-liquid separation compared to the untreated manure (Montes et al., 2013). The liquid part can easily be spread with band spreading techniques. A reduction of ammonia emissions by slurry separation of up to $63 \%$ is possible for the liquid. On the other hand, the liquid part of the separated slurry has a narrow $\mathrm{C} / \mathrm{N}$-ratio resulting in lowering the potential for $\mathrm{N}$ immobilisation in the soil; thus $\mathrm{N}$ is more available for plant uptake.

\section{Inoculum removal from storage tanks}

Inoculum removal significantly reduces $\mathrm{CH}_{4}$ emissions. In a study overwintered liquid dairy manure storage tanks were examined for the impact of inoculum removal in the spring and summer. Overall, there may be greater benefit from removing inoculum in the spring, but emissions were still reduced with fall inoculum removal. The timing of inoculum removal may affect the efficiency of this $\mathrm{CH}_{4}$ mitigation strategy. However, this method may be impractical for larger manure storage tanks.

\section{Flaring methane}

While manure is stored, gas is formed which approximately for $60 \%$ consists of methane. Livestock sector is responsible for reducing the methane formation however methane production cannot be stopped. Therefore, methane flaring can convert methane to $\mathrm{CO}_{2}$. While a certain amount of $\mathrm{CO}_{2}$ is released into the atmosphere with flaring, based on the current estimate of the GWP $\mathrm{CO}_{2}$ is 34 times less harmful than methane itself. In this approach the methane produced in sealed storage tank is captured and burned. In fact, although environmental goals are consequently achieved new methods of limiting methane emissions from livestock farming should be developed.

\section{Anaerobic manure digestion}

Anaerobic digestion of animal manure is promoted as a emission mitigation measure since it captures most of the methane and produces renewable energy. While the biogas digestate can still be used as a an organic fertiliser for nutrient cycling, it should be considered that application of digestate in a similar way as manure may not work and should be treated (infiltrate) and be applied with low emission techniques near the soil surface, e.g. band application or injection. The awareness of the trade-offs and limitations in terms of the biogas feedstocks and the consequences on the nutrient cycling (especially nitrogen recycling capacity) should be taken into account when making decisions related to anaerobic digestion (Hoang et al., 2020). To address this, a recent study in the Netherlands showed that net present value (a feasibility indicator) of biogas plants treating cow manure and sugar beet pulp was negative to an extent that the subsidy was not sufficient to make it feasible while switching to straw combined with cattle manure promoted the cost effectiveness (Achinas et al., 
2019). Overall, high investment and operating costs limit feasibility of anaerobic digestion and therefore subsidy plays a great role in the profitability of this technique (Gebrezgabher et al., 2012). Depending on the size of farm and also the level of technology, large and small scale digesters can be used. According to the research the reduction potential of $50 \%$ to $85 \%$ has been reported (Frank et al., 2018).

\subsubsection{Application of manure}

\section{Application methods and conditions}

The mitigation strategies have been separately discussed for manure in barns and outside storage facilities however upon land application, factors such as manure composition, application method and soil conditions define the potential for GHG emissions (Petersen, 2018). Besides, the conditions in preapplication manure treatments such the retention time in barn and storage temperature can influence the organic matter and nutrients and hence the emissions after field application. For instance, separation of manure solids and anaerobic degradation can mitigate $\mathrm{CH}_{4}$ emission from manure injection, which may otherwise be greater than that from surface-applied manure.

Most of the $\mathrm{N}_{2} \mathrm{O}$ is produced after the manure has been applied to the soil. Controlling the amount of nitrogen available for nitrification and denitrification in soil as well as the availability of degradable carbon and soil oxidation reduction-potential are options to reduce $\mathrm{N}_{2} \mathrm{O}$ emissions that can be achieved through the manure application method. In the first few weeks after application, manure injection often increases $\mathrm{N}_{2} \mathrm{O}$ emission compared with surface applied manure. Dilution, solid separation and anaerobic digestion pre-treatments of manure before injection reduce the availability of degradable carbon and as a result, tend to decrease $\mathrm{N}_{2} \mathrm{O}$ emission.

Surface injection may enhance localised anaerobic conditions surrounding the buried manure slurry which, together with an increased degradable carbon pool, may result in higher $\mathrm{CH}_{4}$ emissions compared to the surface applied manure (Gerber et al., 2013). It should be noted that $\mathrm{CH}_{4}$ emissions from manure injected into soil are relatively low when compared with the reduction in $\mathrm{NH}_{3}$ volatilisation obtained through subsurface injection.

Capturing methane emissions after field application is less feasible therefore most GHG mitigation practices seek to prevent anaerobic conditions and reduce the degradable carbon flux to the soil. Some methods such as diluting the manure or reducing the degradable carbon flux through solid separation or anaerobic degradation are options to alleviate $\mathrm{CH}_{4}$ emissions after manure injection (Amon et al., 2006). Dilution can also affect the GHG emissions indirectly. The amount of ammonia emissions increases by increasing dry matter content of liquid manure (Sommer and Olesen, 1991). A field experiment showed diluting a swine slurry from 4.4 to $2.2 \%$ of DM reduced the $\mathrm{NH}_{3}$ loss by $41 \%$ (Mkhabela et al., 2009).

Since $\mathrm{N}_{2} \mathrm{O}$ production is affected by $\mathrm{N}$ availability, soil temperature, $\mathrm{pH}$ and soil aeration, timing of manure application (e.g. to match crop nutrient demands, avoiding application before rain) and maintaining soil pH above 6.5 (Mkhabela et al., 2006) can affect the $\mathrm{N}_{2} \mathrm{O}$ emissions of soil. Generally, application of manure during cold season is discouraged because of water pollution (during the snowmelt). It is recommended to store the manure during winter and applied during the spring.

\section{Inhibitors for manure application}

As it has been discussed, feed additives work for cows by suppressing specific enzymes that triggers methane production in a cow's rumen and consistently reduces enteric methane emission. Recent studies have tested the effect of inhibitors on reducing the emissions from manure. The most wellknown inhibitors of manure are: DCD, DMPP which can reduce $\mathrm{N}_{2} \mathrm{O}$ emissions by $30 \%$ to $50 \%$ with highest effect in grasslands. Roche et al. (2016) showed that adding a nitrification inhibitor reduces $\mathrm{N}_{2} \mathrm{O}$ emission from urea but an urease inhibitor did not reduce $\mathrm{N}_{2} \mathrm{O}$ emissions relative to Calcium Ammonium Nitrate (CAN). More information on nitrification inhibitors can be found in (Velthof and Rietra, 2018). 
A one-year study at the Department of Agroecology at Aarhus University found that the nitrification inhibitor DMPP significantly reduced nitrous oxide emissions from manure applied to maize on a sandy soil. It was concluded that DMPP and probably also other nitrification inhibitors can be used as a strategy to lower the nitrous oxide emissions from farming. By contrast, DMPP had only a minor effect as a means of reducing nitrate leaching (Nair et al., 2020). Despite of this recent study, in 2016, using nitrification inhibitors to mitigate agricultural $\mathrm{N}_{2} \mathrm{O}$ emission was introduced as a double-edged sword (Lam et al., 2017). This study claimed that while inhibitors decrease emissions of nitrous oxide, they can increase emissions of ammonia which is later converted to nitrous oxide. They recommend these effects are considered when evaluating inhibitors as a mitigation technology. To alleviate this problem, the researchers suggest ammonia mitigation measures, such as urease inhibitors, could be used alongside nitrification inhibitors. Urease inhibitors limit the breakdown of urea, a process that results in ammonia. Adding a urease inhibitor to urea has shown to decrease ammonia emissions.

\subsection{Green energy}

The most energy consuming subsector of livestock production is milk production followed by pig and broiler production. Therefore, it is very substantial to adapt, design and demonstrate easily replicable renewable energy efficient solutions (including smart farming technologies/systems), capable to:

4. Establish optimal conditions in the indoor environment of the energy intensive agricultural buildings and to reduce direct energy use in crop (feed) production systems. This is not the case for open dairy barns, but it is common for pig and poultry barns.

5. Produce the required feed for the annual needs of the inhabited animals using (a) biofuels for selfpropelled machinery (tractors, sprayers, fertiliser spreaders either granular or liquid, mowers and harvesters), (b) pulled machinery electrification and (c) smart farming techniques and technologies.

6. Make use of renewable and energy efficiency technologies, measures and practices in livestock buildings, in order to change the energy consumption mix and reduce the farm's dependency on fossil fuel and electricity providers, such as:

a. Integrating innovative ground heat pumps, for the precise environment control of livestock buildings, since it is the most appropriate to cover effectively from both technical and economical point of view thermal needs (for heating, cooling and dehumidification.

b. PVs to cover electricity consumptions (lighting, equipment, heat pump).

c. Adopting energy efficiency measures that will directly reduce the energy use (e.g. LED for lighting, high efficiency electric motors of livestock equipment).

d. Smart control of energy processes and optimal energy management of energy and demand side are of key importance towards maximising the use of energy.

e. Biofuels (especially biogas derived from combined digestion of animal waste and crop residues optimising $\mathrm{C} / \mathrm{N}$ ratio). The use of biodiesel and bioethanol is often discussed, as it requires extra land.

f. Thermal and/or electricity storage where appropriate.

The energy consumption of compound feed is high, due to all steps in the production and processing chain, including transports. Reducing energy use in compound feed is beyond the scope of the dairy farmer. However, compound feed producers can be stimulated to reduce the fossil energy use in the production chain and provide low emission compound feed.

\subsection{Factors influencing the selection of GHG mitigation actions}

Given the fact that the variety of the livestock production systems in Netherlands, USA, Australia, and New Zealand is great, it is essential to consider this variety for determining and implementing the most appropriate strategies. Depending on the challenges farmers face, production/farming system and economic issues, various GHG mitigation strategies are applicable in livestock production. In the following sections these issues are discussed. 


\section{Challenges farmers face}

Applying a GHG mitigation option at farm level, different parameters or criteria are considered by farmers. To compare the provided GHG mitigation strategies easier, the investigated strategies were evaluated qualitatively based on the GHG reduction potential, skill requirement for applying the strategy, required investment, and the time investment (hours or week) (Table 4.1). It should be noted that the data provided for the GHG reduction potential demonstrate the potential estimated for that specific category. As it has been mentioned previously, based on the FAO data, feed production contributes around $45 \%$ of livestock emissions and after that enteric fermentation accounts for $39 \%$ and followed by manure storage (10\%) and processing and transportation (6\%).

Table 4.1 GHG mitigation potential of various strategies in livestock production

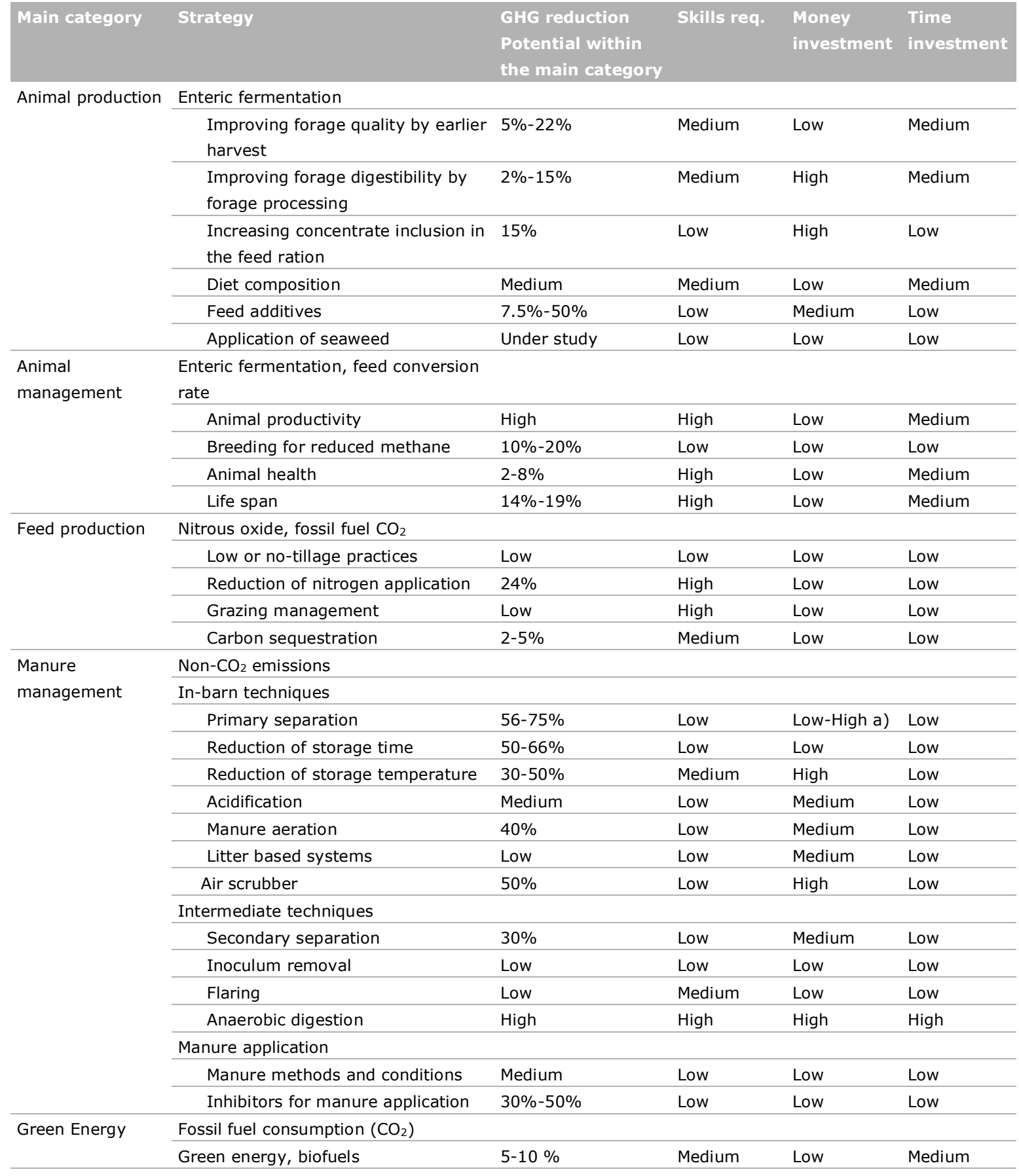

a) Depending on: (a) a new barn is built or (b) the present barn is renovated, the investment will be low or high, respectively. 


\section{Farming system}

Figure 4.3 shows the GHG mitigation strategies for different production systems (farm types). Depending on the production system (land based or footloose and intensive or extensive production), various GHG mitigation strategies are applicable. Some mitigation options are applicable for all production systems (e.g. animal health management, increasing life span, animal breeding, and increasing animal productivity) while others are specific options for intensive/extensive and land/footloose production systems. The diagram shows where mitigation options can be the most effective however, it does not mean that these options cannot be implemented on other farm types.

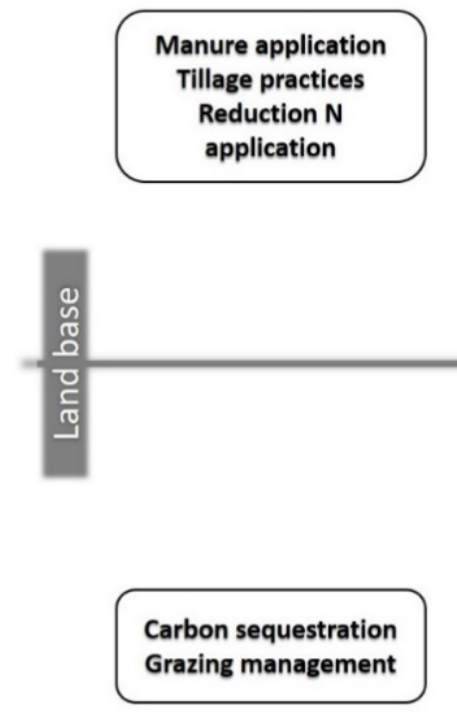

\section{Intensive production}

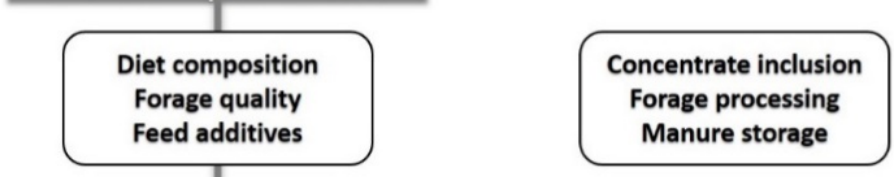

Extensive production

Figure 4.3 GHG mitigation options for different production system (farm types).

For example in the Netherlands, the top seven common mitigation options are: (1) reducing young stock number; (2) increasing milk production per cow per year; (3) increasing the clover share on grassland; (4) increasing grass yield; (5) developing the solar energy; (6) reducing manure fermentation (by manure management); and (7) improving feed efficiency.

The mitigation strategies differ considerably for different dairy production system (specially for small scale and subsistence farming). Due to the context of small scale farming such as farm size, education, technology, and financial assets, the prioritisation of mitigation options is completely different. Therefore, with a broader application of GHG mitigation options, we have the to deal with this issue. Although Figure 4.3 identifies different farming systems, these can all be considered as specialised dairy production systems in industrialised countries. From a global perspective, these systems all belong to the blue group in Figure 4.4, where optimising animal performance plays an important role. In the case of dairy production systems in less industrialised countries in Africa, Asia and partially Latin America, these are mainly multifunctional smallholder systems with low input levels and low animal productivity. Mitigation for the systems in the green segment are focusing on the application of existing technology, the development of markets and a supporting infrastructure. The link with general food security and the attention for food-feed competition is very important in these smallholder systems. 


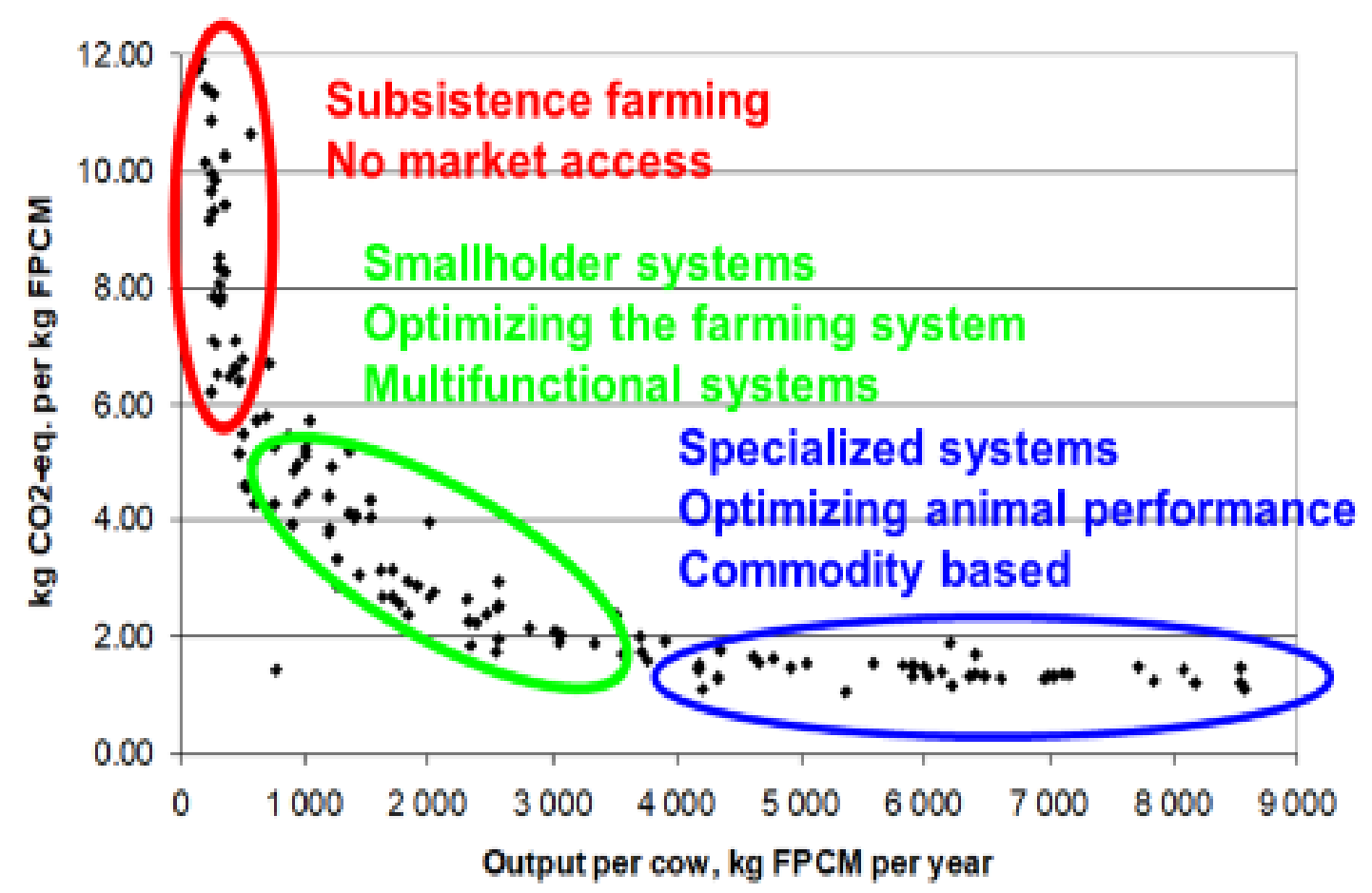

Figure 4.4 Relationship between total GHG emissions and output per cow for various farming systems. Each dot represents a country

Source: Gerber et al. (2011)

\section{Economic issues}

When a wide range of GHG mitigation options are feasible, it is difficult to identify the most economically efficient option. One of the useful approaches to overcome this issue and determine the impacts of interventions on both GHG reduction and economic aspects is the Marginal Abatement Cost Curve (MACC) (Moran et al., 2011). Van den Pol et al. (2013) studied the cost-effectiveness of GHG reduction options for dairy products in the Netherlands and their findings are presented in Figure 5. Each box represents the options for GHG emissions reduction. The width of each box shows the emissions reduction potential in a particular year compared to the business-as-usual (the wider the bar, the more $\mathrm{CO}_{2}$ reduction). The height of each box represents the average net cost per ton of $\mathrm{CO}_{2}$ eq (carbon dioxide equivalent) being reduced through the mitigation activity in that year. The surface of the box (width $\times$ height) reflects the potential costs. Measures with the negative cost effectiveness (at the left side of the horizontal axis) are cost saving (make money) interventions while the measures in the right side (with a positive cost effectiveness) are the costly interventions. The strategies which have been discussed are as follows (the percentages between brackets are the GHG reduction potentials related to the specific activity):

1. Feed: $1.5 \mathrm{~kg} \mathrm{DM}$ wheat yeast concentrate per cow per day (0-20\%);

2. Farm: $25 \%$ of the land $6 \mathrm{~km}$ closer to home $(0-20 \%)$;

3. Energy related strategy: Tractor $65 \mathrm{~kW}$ instead of $85 \mathrm{~kW}$ for self-mowing, raking, tedding, ploughing and fertilising. (20-40\%);

4. Crop and soil: a $500 \mathrm{~kg}$ DM more yield per cut (heavier cut) (20-40\%);

5. Crop and soil: applying $10 \%$ reseeding less (20-40\%);

6. Animal management: $500 \mathrm{~kg}$ milk increase per cow (from 8,100 to 8,600) due to better use of roughage with the same number of cows (same barn, same concentrate per cow, delivering more milk, none quota costs) (20-40\%);

7. Energy related strategy: Applying wind energy (0-20\%);

8. Animal management: 1 piece less young stock per 10 dairy cows (from 8 to 7 ) (40-60\%); 
9. Animal management: $500 \mathrm{~kg}$ milk increase per cow (from 8,100 to 8,600 ) due to better use of roughage, less cows (same quantity of concentrate, same barn, same milk delivery) (20-40\%);

10. Energy related strategy: Application of solar energy (40-60\%);

11. Energy related strategy: Heat recovery $(20-40 \%)$;

12. Energy related strategy: Use pre-cooler (40-60\%);

13. Crop and soil: Over seeding instead of reseeding (20-40\%);

14. Feed: $10 \%$ lower crude protein content concentrate, same price concentrate $(20-40 \%)$;

15. Feed: $2 \mathrm{~kg}$ DM by-products per cow per day additional feed (20-40\%);

16. Crop and soil: $10 \%$ area plant silage for young stock instead of grass $(0-20 \%)$;

17. Crop and soil: Replacing maize by corncob meal or Corncob mix (10\% soil) $(0-20 \%)$;

18. Crop and soil: From $10 \%$ to $20 \%$ maize in the crop plan (0-20\%);

19. Fertilisation: Not applying fertiliser after August 1 (20-40\%);

20. Feed: Feed low-methane concentrate (40-60\%);

21. Feed: replacing $2.5 \mathrm{~kg}$ of concentrate with grain (20-40\%);

22. Fertilisation: spreading $50 \mathrm{~kg} \mathrm{~N}$ fertiliser per ha grassland less (20-40\%);

23. Farm: More limited grazing (approximately $4 \mathrm{~kg}$ of roughage extra per day feeding) (0-20\%);

24. Fertilisation: Applying spring fertiliser (40-60\%);

25. Food: Nitrate (20-40\%);

26. Fertilisation: Applying manure separation (20-40\%);

27. Feed: $820 \mathrm{~kg}$ concentrate per cow replaced by $500 \mathrm{~kg}$ Nutex per cow $(0-20 \%)$;

28. Fertilisation: 2 months more manure storage and application until July $1(20-40 \%)$;

29. Energy: Applying co-fermentation (0-20\%).

Cotter et al. (2015) studied the cost effectiveness of various GHG mitigation scenarios including (1) Grape marc (feeds produced from the residues of wine industry); (2) Wheat feeding; (3) Genetic modification; (4) Vaccination; (5) Biochar; (6) Application of algae as feed component; (7) Feed supplement for reduction of enteric fermentation (adding Nitrooxypropanol-NOP); (8) Nitrate as a feed supplement; and (9) application of plant bioactive compounds, for dairy system in Australia

(Figure 4.6).

Figure 4.5 and 4.6 are the examples of MACC graphs which shows the cost effectiveness of various GHG mitigation scenarios for diary system in the Netherland and Australia. In a subsequent project, the country specific MACCs can be developed for each country as a support tool to make decisions. 


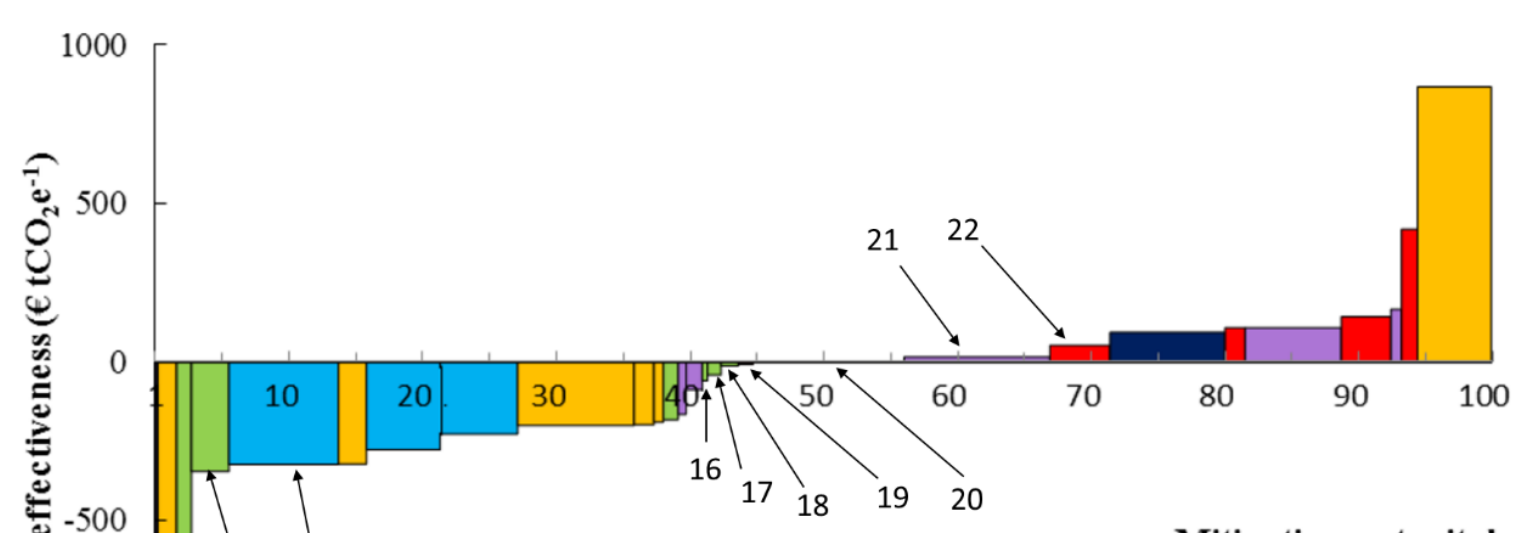

Mitigation potenital

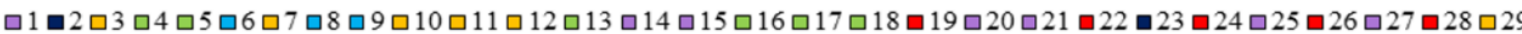

Figure 4.5 Marginal abatement cost curve (MACC) of GHG mitigation strategies for dairy in the Netherlands

Source: Van den Pol et al. (2013).

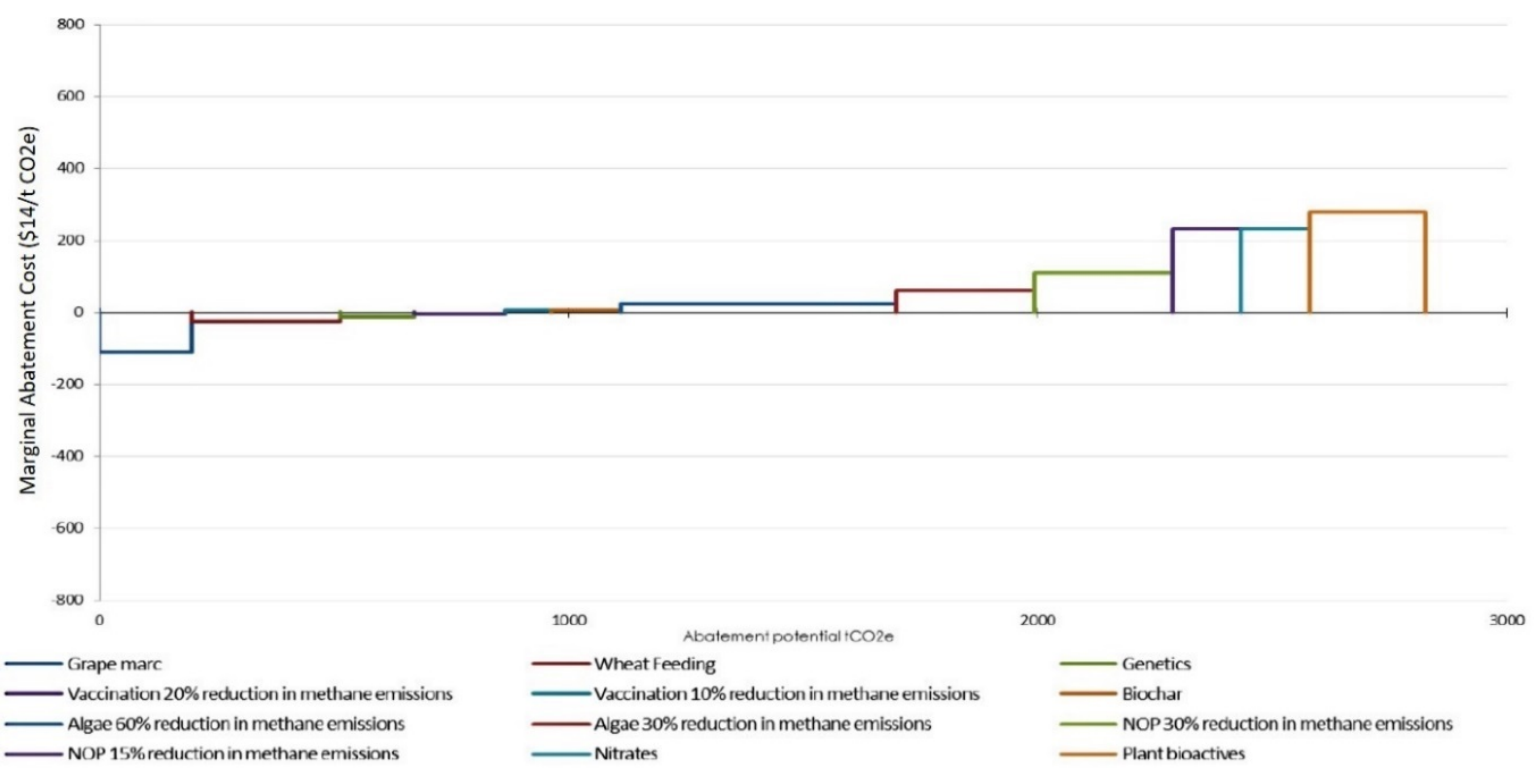

Figure 4.6 Marginal abatement cost curve (MACC) of GHG mitigation strategies for dairy in Australia Source: Cotter et al. (2015)

\subsection{Relation to GHG monitoring stage}

After defining the mitigation options, it is essential to measure and calculate the impact (size of reduction) of the mitigation intervention. A number of challenges exists when determining the impact of GHG mitigation strategies. The first challenge is the data availability: many farm data on inputs, feed consumption, manure storage etc. have to be collected in a standardised way and have to be available for automated, digital systems. The second is the reliability of the collected data, it is preferred to collect data from formalised data collection systems and to involve chain partners such as 
the dairy industry, fertiliser and feed suppliers, accountancy offices, etc. The third is the proper registration of the mitigation interventions. Some are already present in current monitoring and accounting systems. Others need to be filled in manually and in addition to the formalised data collection. They have to be checks to monitor data quality and to prevent mistakes and fraud. This implies that a centralised data strategy can be very useful.

Measurement of GHG emissions at farm level is a subject of research, but not yet operational. At this moment technologies are developed to measure emissions instead of calculating. The accuracy and costs of the measurements are still not at acceptable levels. However, this might be an option on the longer term.

There are many options for emission reduction. The efficacy depends often on the local conditions, farm type, and farmers' skills, which makes it difficult to mention exact data for reduction potentials. A long term study for Dutch conditions showed a reduction potential for the dairy sector of $50 \%$ (Vellinga et al., 2018). This is confirmed in a more detailed study of a research group of Wageningen Research (Lesschen et al., 2020a). A higher reduction potential between 80 and $90 \%$ can be realised by applying the maximum of technology and fully closed barns, with complete confinement of dairy cattle (Vellinga et al., 2018).

In the public debate many new agricultural systems are mentioned, like regenerative agriculture or circular food systems. The aim of a circular food system is reducing resource consumption and emission to the environment by closing the cycle of materials and substances. To achieve circularity first the losses of materials and substances should be prevented, otherwise they should be recycled or reused.

Circularity leads to less use of non-renewable resources, prevent losses and encourage the regenerative food systems.

In all systems, reduction of emissions by reducing the $\mathrm{N}$ input and reducing the methane formation in feed digestion (enteric fermentation) and manure storage are the key. This will also have positive effects on the other types of $\mathrm{N}$ losses (ammonia volatilisation and nitrate leaching) to the environment. The higher claims of carbon sequestration in regenerative agriculture have been extensively reviewed by Garnett et al. (2017) and considered as an overestimation of the potential. It can be stated that the GHG mitigation options can be considered as strategies toward a circular and regenerative food system. However, in a circular system the priority of using resources is for humans' food production and the role of farm animals in the food system is converting by-products which cannot be consumed by humans. It also consists of the losses in the process of food production. For example, in a circular system, livestock should no longer be fed by fish meal harvested from sea. These types of feed materials should be replaced by waste-fed insects or plants which are not edible for humans. 


\section{References and websites}

\section{References chapter 2}

Allen, M.R. et al. 2018. A solution to the misrepresentations of CO2-equivalent emissions of shortlived climate pollutants under ambitious mitigation. npj Clim. Atmos. Sci. 1, 16.

Anonymous, 2020. New Greenhouse Gas Protocol Standards/Guidance on Carbon Removals and Land Use. https://ghgprotocol.org/blog/new-greenhouse-gas-protocol-standardsguidance-carbonremovals-and-land-use. (Accessed (Last access: 09.09.2020.

Broekema, R., Tyszler, M., van't Veer, P., Kok, F.J., Martin, A., Lluch, A., Blonk, H.T.J., 2020. Futureproof and sustainable healthy diets based on current eating patterns in the Netherlands. The American Journal of Clinical Nutrition.

Carrillo Pineda, A., Chang, A., Faria, P. 2020. Foundations for science-based net-zero target setting in the corporate sector. Version 1.0. CDP. https://sciencebasedtargets.org/wpcontent/uploads/2020/09/foundations-for-net-zero-full-paper.pdf

Chen, C., Chaudhary, A., Mathys, A., 2019. Dietary change scenarios and implications for environmental, nutrition, human health and economic dimensions of food sustainability. Nutrients $11(4), 856$.

Fisher, B., Nakicenovic, N., Alfsen, K., Corfee Morlot, J., de la Chesnaye, F., Hourcade, J.C., Jiang, K., Kainuma, M., La Rovere, E., Matysek, A., 2007. Issues related to mitigation in the long term context. In B. Metz, O. R. Davidson, P. R. Bosch, R. Dave and L. A. Meyer (Eds.), Climate change 2007: Mitigation. Contribution of working group III to the fourth assessment report of the intergovernmental panel on climate change (pp. 171-250). Cambridge: Cambridge University Press. Cambridge, UK: Cambridge University Press.

Masson-Delmotte, V., Zhai, P., Pörtner, H.O., Roberts, D., Skea, J., Shukla, P.R., Pirani, A., Moufouma-Okia, W., Péan, C., Pidcock, R., Connors, S., Matthews, J.B.R., Chen, Y., Zhou, X., Gomis, M.I., Lonnoy, E., Maycock, T., Tignor, M., Waterfield, T., 2018. Global Warming of $1.5^{\circ} \mathrm{C}$. An IPCC Special Report on the impacts of global warming of $1.5^{\circ} \mathrm{C}$ above pre-industrial levels and related global greenhouse gas emission pathways, in the context of strengthening the global response to the threat of climate change, sustainable development, and efforts to eradicate poverty.

Reijs, J., Beldman, A., Zijlstra, J., Vrolijk, M. \& Hoes, A. C., Building farm-level sustainability programmes in agribusiness: a 5 step cycle based on lessons from working with the dairy industry 2021, Den Haag: Wageningen University \& Research. 33 p. Research output: Book/Report > Report > Professional https://edepot.wur.nl/543101

Smith, P., Bustamante, M., Ahammad, H., Clark, H., Dong, H., Elsiddig, E.A., Haberl, H., Harper, R., House, J., Jafari, M., Masera, O., Mbow, C., Ravindranath, N.H., Rice, C.W., Abad, C.R., Romanovskaya, A., Sperling, F., Tubiello, F.N., 2014. Agriculture, forestry and other land use (AFOLU). In: Edenhofer O, Pichs-Madruga R, Sokona Y, et al., editors. Climate change 2014: mitigation of climate change. Contribution of working group III to the ffth assessment report of the intergovernmental panel on climate change. Cambridge, and New York: Cambridge University Press; 2014. p. 811-922.

Willett, W., Rockström, J., Loken, B., Springmann, M., Lang, T., Vermeulen, S., Garnett, T., Tilman, D., DeClerck, F., Wood, A., 2019. Food in the Anthropocene: the EAT-Lancet Commission on healthy diets from sustainable food systems. The Lancet 393(10170), 447-492.

Wollenberg, E., Richards, M., Smith, P., Havlík, P., Obersteiner, M., Tubiello, F.N., Herold, M., Gerber, P., Carter, S., Reisinger, A., 2016. Reducing emissions from agriculture to meet the $2 \mathrm{C}$ target. Global change biology 22(12), 3859-3864.

WRI, 2018. Half a Degree and a World Apart: The Difference in Climate Impacts Between $1.5^{\circ} \mathrm{C}$ and $2^{\circ} \mathrm{C}$ of Warming. https://www.wri.org/. (Accessed 09.09.2020). 


\section{References chapter 3:}

Australia, Dairy. "Australian dairy industry sustainability report 2018." (2019).

Bills, J. (2004). The Australian dairy industry. Milchwissenschaft, 59(11-12), 584-586.

Doornewaard, G.J. ; Reijs, J.W. ; Beldman, A.C.G. ; Jager, J.H. ; Hoogeveen, M.W. (2020)

Wageningen : Wageningen Economic Research, (Wageningen Economic Research rapport 2020019) - 225

Eve, M., Pape, D., Flugge, M., Steele, R., Man, D., Riley-Gilbert, M., \& Biggar, S. (2014). Quantifying greenhouse gas fluxes in agriculture and forestry: Methods for entity-scale inventory. USDA Technical Bulletin 1939, July, 1-606.

http://www.usda.gov/oce/climate_change/techguide/USDA_CCPO_GHG_draft_082213.pdf

GREENHOUSE GAS INVENTORY REPORT - FY19. (2019). Synlait Milk LTD.

Rotz, A. C., Chianese, D. S., Montes, F., Hafner, S., \& Bonifacio, H. F. (2015). Dairy Gas Emissions Model (DairyGEM). Reference Manual, September, 137. http://www.ars.usda.gov/sp2UserFiles/Place/80700500/DairyGEMReferenceManual.pdf

Sheng, Y., \& Xu, X. (2019). The productivity impact of climate change: Evidence from Australia's Millennium drought. Economic Modelling, 76(July), 182-191. https://doi.org/10.1016/j.econmod.2018.07.031

The European Dairy Association. (2018). Product Environmental Footprint Category Rules for Dairy Products. https://ec.europa.eu/environment/eussd/smgp/pdf/PEFCR-DairyProducts_2018-0425_V1.pdf

Today, U. S. D. F. (2014). U.S. Dairy Industry.

US EPA. (2020). Inventory of U.S. greenhouse gas emissions and sinks: 1990-2009. Federal Register, 76(36), 10026.

Van Dijk, W., Schroder, J. J., Sebek, L., Oenema, J., Conijn, J. G., Vellinga, T. V., De Boer, J., De Haan, M. H. ., \& Verloop, J. (2020). Rekenregels van de KringloopWijzer 2019. https://library.wur.nl/WebQuery/wurpubs/fulltext/512610

Victoria, D. E. P. I. (2019). Dairy farm monitor project, Victoria annual report 2018/19.

\section{References chapter 4:}

Achinas, S., Martherus, D., Krooneman, J., Euverink, G.J.W., 2019. Preliminary Assessment of a Biogas-Based Power Plant from Organic Waste in the North Netherlands. Energies 12, 4034.

Ahmed, J., Almeida, E., Aminetzah, D., Denis, N., Henderson, K., Katz, J., Kitchel, H., Mannion, P., 2020. Agriculture and climate change: Reducing emissions through improved farming practices. McKinsey \& Company.

Amon, B., Kryvoruchko, V., Moitzi, G., Amon, T., 2006. Greenhouse gas and ammonia emission abatement by slurry treatment. International Congress Series. Elsevier, pp. 295-298.

Beauchemin, K., McGinn, S., Martinez, T., McAllister, T., 2007. Use of condensed tannin extract from quebracho trees to reduce methane emissions from cattle. Journal of Animal Science 85, 19901996.

Beauchemin, K.A., McAllister, T.A., McGinn, S.M., 2009. Dietary mitigation of enteric methane from cattle. CAB Reviews: Perspectives in Agriculture, Veterinary Science, Nutrition and Natural Resources 4, 1-18.

Bell, M., Wall, E., Russell, G., Morgan, C., Simm, G., 2010. Effect of breeding for milk yield, diet and management on enteric methane emissions from dairy cows. Animal Production Science 50, 817826.

Beukes, P., Gregorini, P., Romera, A., Levy, G., Waghorn, G., 2010. Improving production efficiency as a strategy to mitigate greenhouse gas emissions on pastoral dairy farms in New Zealand. Agriculture, Ecosystems \& Environment 136, 358-365.

Borhan, M.S., Mukhtar, S., Capareda, S., Rahman, S., 2012. Greenhouse gas emissions from housing and manure management systems at confined livestock operations. Waste management-an integrated vision. Rijeka (Croatia): InTech, 259-296.

Broekema, R., Tyszler, M., van't Veer, P., Kok, F.J., Martin, A., Lluch, A., Blonk, H.T.J., 2020. Futureproof and sustainable healthy diets based on current eating patterns in the Netherlands. The American Journal of Clinical Nutrition. 
Brown, E.G., Anderson, R.C., Carstens, G.E., Gutierrez-Bañuelos, H., McReynolds, J.L., Slay, L.J., Callaway, T.R., Nisbet, D.J., 2011. Effects of oral nitroethane administration on enteric methane emissions and ruminal fermentation in cattle. Animal Feed Science and Technology 166, 275-281.

Calvet, S., Hunt, J., Misselbrook, T.H., 2017. Low frequency aeration of pig slurry affects slurry characteristics and emissions of greenhouse gases and ammonia. biosystems engineering 159, 121-132.

Chen, C., Chaudhary, A., Mathys, A., 2019. Dietary change scenarios and implications for environmental, nutrition, human health and economic dimensions of food sustainability. Nutrients $11,856$.

Chen, M., Shi, J., 2018. Effect of rotational grazing on plant and animal production. Mathematical Biosciences \& Engineering 15, 393.

Cotter, J., Glass, R., Black, J., Madden, P., Davison, T., 2015. A marginal abatement cost analysis of practice options related to the NLMP program.

CRV, 2020. CRV-Jaarstatistieken 2018 - VOOR NEDERLAND.

De Haas, Y., Windig, J.J., Calus, M.P.L., Dijkstra, J., De Haan, M.H.A., Bannink, A., Veerkamp, R., 2011. Genetic parameters for predicted methane production and potential for reducing enteric emissions through genomic selection. Journal of dairy science 94, 6122-6134.

De Vries, J.W., Melse, R.W., 2017. Comparing environmental impact of air scrubbers for ammonia abatement at pig houses: A life cycle assessment. Biosystems Engineering 161, 53-61.

EC, 2002. Question and Answers on antibiotics in feed: European Commission.

FAO, 2017. Global Livestock Environmental Assessment Model (GLEAM). Rome (Italy): Food and Agriculture Organization of the United Nations (FAO).

Fisher, B., Nakicenovic, N., Alfsen, K., Corfee Morlot, J., de la Chesnaye, F., Hourcade, J.C., Jiang, K., Kainuma, M., La Rovere, E., Matysek, A., 2007. Issues related to mitigation in the long term context. In B. Metz, O. R. Davidson, P. R. Bosch, R. Dave and L. A. Meyer (Eds.), Climate change 2007: Mitigation. Contribution of working group III to the fourth assessment report of the intergovernmental panel on climate change (pp. 171-250). Cambridge: Cambridge University Press. Cambridge, UK: Cambridge University Press.

Frank, S., Beach, R., Havlík, P., Valin, H., Herrero, M., Mosnier, A., Hasegawa, T., Creason, J., Ragnauth, S., Obersteiner, M., 2018. Structural change as a key component for agricultural nonCO 2 mitigation efforts. Nature communications 9, 1-8.

Fuchs, K., Hörtnagl, L., Buchmann, N., Eugster, W., Snow, V., Merbold, L., 2018. Management matters; testing a mitigation strategy for nitrous oxide emissions using legumes on intensively managed grassland. Biogeosciences Discussions.

Garnett, T., Godde, C., Muller, A., Röös, E., Smith, P., De Boer, I.J.M., zu Ermgassen, E., Herrero, M., Van Middelaar, C.E., Schader, C., 2017. Grazed and confused?: Ruminating on cattle, grazing systems, methane, nitrous oxide, the soil carbon sequestration question-and what it all means for greenhouse gas emissions. FCRN.

Gebrezgabher, S.A., Meuwissen, M.P.M., Lansink, A.G.J.M.O., 2012. Energy-neutral dairy chain in the Netherlands: An economic feasibility analysis. Biomass and Bioenergy 36, 60-68.

Gerber, P., Vellinga, T., Opio, C., Steinfeld, H., 2011. Productivity gains and greenhouse gas emissions intensity in dairy systems. Livestock Science 139, 100-108.

Gerber, P.J., Henderson, B., Makkar, H.P.S., 2013. Mitigation of greenhouse gas emissions in livestock production: a review of technical options for non-CO2 emissions. Food and Agriculture Organization of the United Nations (FAO).

Groenestein, C.M., Smits, M.C.J., Huijsmans, J.F.M., Oenema, O., 2011. Measures to reduce ammonia emissions from livestock manures: now, soon and later. Wageningen UR Livestock Research.

Grossi, G., Goglio, P., Vitali, A., Williams, A.G., 2019. Livestock and climate change: impact of livestock on climate and mitigation strategies. Animal Frontiers 9, 69-76.

Gutierrez-Bañuelos, H., Anderson, R.C., Carstens, G.E., Slay, L.J., Ramlachan, N., Horrocks, S.M., Callaway, T.R., Edrington, T.S., Nisbet, D.J., 2007. Zoonotic bacterial populations, gut fermentation characteristics and methane production in feedlot steers during oral nitroethane treatment and after the feeding of an experimental chlorate product. Anaerobe 13, 21-31.

Harmsen, J.H.M., 2019. Non-CO2 Greenhouse Gas Mitigation in the 21st Century. Universiteit Utrecht. Hellwing, A.L.F., Weisbjerg, M.R., Møller, H.B., 2014. Enteric and manure-derived methane emissions and biogas yield of slurry from dairy cows fed grass silage or maize silage with and without supplementation of rapeseed. Livestock Science 165, 189-199. 
Herrero, M., Henderson, B., Havlík, P., Thornton, P.K., Conant, R.T., Smith, P., Wirsenius, S., Hristov, A.N., Gerber, P., Gill, M., 2016. Greenhouse gas mitigation potentials in the livestock sector. Nature Climate Change 6, 452-461.

Hilhorst, M.A., Melse, R.W., Willers, H.C., Groenestein, C.M., Monteny, G.J., 2002. Reduction of methane emissions from manure. Non- $\mathrm{CO} 2$ greenhouse gases: scientific understanding, control options and policy aspects, pp. 435-440.

Hoang, D.L., Davis, C., Moll, H.C., Nonhebel, S., 2020. Impacts of biogas production on nitrogen flows on Dutch dairy system: Multiple level assessment of nitrogen indicators within the biogas production chain. Journal of Industrial Ecology.

Jayasundara, S., Ranga Niroshan Appuhamy, J.A.D., Kebreab, E., Wagner-Riddle, C., 2016. Methane and nitrous oxide emissions from Canadian dairy farms and mitigation options: An updated review. Canadian Journal of Animal Science 96, 306-331.

Kinley, R.D., Martinez-Fernandez, G., Matthews, M.K., de Nys, R., Magnusson, M., Tomkins, N.W., 2020. Mitigating the carbon footprint and improving productivity of ruminant livestock agriculture using a red seaweed. Journal of Cleaner Production, 120836.

Knapp, J.R., Laur, G.L., Vadas, P.A., Weiss, W.P., Tricarico, J.M., 2014. Invited review: Enteric methane in dairy cattle production: Quantifying the opportunities and impact of reducing emissions. Journal of Dairy Science 97, 3231-3261.

Król-Badziak, A., Pishgar-Komleh, S.H., Rozakis, S., Księżak, J., 2021. Environmental and socioeconomic performance of different tillage systems in maize grain production: Application of Life Cycle Assessment and Multi-Criteria Decision Making. Journal of Cleaner Production 278, 123792.

Lam, S.K., Suter, H., Mosier, A.R., Chen, D., 2017. Using nitrification inhibitors to mitigate agricultural N2O emission: a double-edged sword? Global Change Biology 23, 485-489.

Lesschen, J.P., Reijs, J., Vellinga, T., Verhagen, J., Kros, H., de Vries, M., Jongeneel, R., Slier, T., Martinez, A.G., Vermeij, I., Daatselaar, C., 2020a. Scenariostudie perspectief voor ontwikkelrichtingen Nederlandse landbouw in 2050. Wageningen Environmental Research.

Lesschen, J.P., Reijs, J.W., Vellinga, T.V., Verhagen, J., Kros, H., de Vries, M., Jongeneel, R.A., Slier, T., Martinez, A.G., Vermeij, I., 2020b. Landbouw in Nederland in 2050: Effecten van ontwikkelrichtingen. Wageningen Environmental Research.

Li, X., Norman, H.C., Kinley, R.D., Laurence, M., Wilmot, M., Bender, H., de Nys, R., Tomkins, N., 2018. Asparagopsis taxiformis decreases enteric methane production from sheep. Animal Production Science 58, 681-688.

MacLeod, M., Eory, V., Gruère, G., Lankoski, J., 2015. Cost-effectiveness of greenhouse gas mitigation measures for agriculture: a literature review.

Masson-Delmotte, V., Zhai, P., Pörtner, H.O., Roberts, D., Skea, J., Shukla, P.R., Pirani, A., Moufouma-Okia, W., Péan, C., Pidcock, R., Connors, S., Matthews, J.B.R., Chen, Y., Zhou, X., Gomis, M.I., Lonnoy, E., Maycock, T., Tignor, M., Waterfield, T., 2018. Global Warming of $1.5^{\circ} \mathrm{C}$. An IPCC Special Report on the impacts of global warming of $1.5^{\circ} \mathrm{C}$ above pre-industrial levels and related global greenhouse gas emission pathways, in the context of strengthening the global response to the threat of climate change, sustainable development, and efforts to eradicate poverty.

Melse, R.W., Ogink, N.W.M., 2005. Air scrubbing techniques for ammonia and odor reduction at livestock operations: Review of on-farm research in the Netherlands. Transactions of the ASAE 48, 2303-2313.

Mkhabela, M.S., Gordon, R., Burton, D., Madani, A., Hart, W., Elmi, A., 2006. Ammonia and nitrous oxide emissions from two acidic soils of Nova Scotia fertilised with liquid hog manure mixed with or without dicyandiamide. Chemosphere 65, 1381-1387.

Mkhabela, M.S., Gordon, R., Burton, D., Smith, E., Madani, A., 2009. The impact of management practices and meteorological conditions on ammonia and nitrous oxide emissions following application of hog slurry to forage grass in Nova Scotia. Agriculture, Ecosystems \& Environment 130, 41-49.

Mohankumar Sajeev, E.P., Winiwarter, W., Amon, B., 2018. Greenhouse gas and ammonia emissions from different stages of liquid manure management chains: abatement options and emission interactions. Journal of environmental quality $47,30-41$.

Mollenhorst, H., de Haas, Y., 2019. The contribution of breeding to reducing environmental impact of animal production. Wageningen Livestock Research. 
Moller, H.B., Hansen, J.D., Sorensen, C.A.G., 2007. Nutrient recovery by solid-liquid separation and methane productivity of solids. Transactions of the ASABE 50, 193-200.

Monteny, G.J., 2000. Modelling of ammonia emissions from dairy cow houses.

Montes, F., Meinen, R., Dell, C., Rotz, A., Hristov, A.N., Oh, J., Waghorn, G., Gerber, P.J., Henderson, B., Makkar, H., 2013. SPECIAL TOPICS-mitigation of methane and nitrous oxide emissions from animal operations: II. A review of manure management mitigation options. Journal of animal science 91, 5070-5094.

Moran, D., Macleod, M., Wall, E., Eory, V., McVittie, A., Barnes, A., Rees, R., Topp, C.F.E., Moxey, A., 2011. Marginal abatement cost curves for UK agricultural greenhouse gas emissions. Journal of Agricultural Economics 62, 93-118.

Mostert, P.F., Bokkers, E.A.M., De Boer, I.J.M., Van Middelaar, C.E., 2019. Estimating the impact of clinical mastitis in dairy cows on greenhouse gas emissions using a dynamic stochastic simulation model: a case study. animal 13, 2913-2921.

Mostert, P.F., van Middelaar, C.E., Bokkers, E.A.M., de Boer, I.J.M., 2018a. The impact of subclinical ketosis in dairy cows on greenhouse gas emissions of milk production. Journal of Cleaner Production 171, 773-782.

Mostert, P.F., van Middelaar, C.E., de Boer, I.J.M., Bokkers, E.A.M., 2018b. The impact of foot lesions in dairy cows on greenhouse gas emissions of milk production. Agricultural Systems 167, 206-212.

Nair, D., Baral, K.R., Abalos, D., Strobel, B.W., Petersen, S.O., 2020. Nitrate leaching and nitrous oxide emissions from maize after grass-clover on a coarse sandy soil: Mitigation potentials of 3, 4dimethylpyrazole phosphate (DMPP). Journal of Environmental Management 260, 110165.

Petersen, S.O., 2018. Greenhouse gas emissions from liquid dairy manure: Prediction and mitigation. Journal of dairy science 101, 6642-6654.

Roche, L., Forrestal, P., Lanigan, G., Richards, K., Shaw, L., Wall, D., 2016. Impact of fertiliser nitrogen formulation, and $\mathrm{N}$ stabilisers on nitrous oxide emissions in spring barley. Agriculture, Ecosystems \& Environment 233, 229-237.

Roque, B.M., Salwen, J.K., Kinley, R., Kebreab, E., 2019. Inclusion of Asparagopsis armata in lactating dairy cows' diet reduces enteric methane emission by over 50 percent. Journal of Cleaner Production 234, 132-138.

Russell, J.B., Houlihan, A.J., 2003. Ionophore resistance of ruminal bacteria and its potential impact on human health. FEMS microbiology reviews 27, 65-74.

Salvador, S., Corazzin, M., Romanzin, A., Bovolenta, S., 2017. Greenhouse gas balance of mountain dairy farms as affected by grassland carbon sequestration. Journal of environmental management 196, 644-650.

Seddaiu, G., Iocola, I., Farina, R., Orsini, R., Iezzi, G., Roggero, P.P., 2016. Long term effects of tillage practices and $\mathrm{N}$ fertilization in rainfed Mediterranean cropping systems: durum wheat, sunflower and maize grain yield. European Journal of Agronomy 77, 166-178.

Smith, P., Bustamante, M., Ahammad, H., Clark, H., Dong, H., Elsiddig, E.A., Haberl, H., Harper, R., House, J., Jafari, M., Masera, O., Mbow, C., Ravindranath, N.H., Rice, C.W., Abad, C.R., Romanovskaya, A., Sperling, F., Tubiello, F.N., 2014. Agriculture, forestry and other land use (AFOLU). In: Edenhofer O, Pichs-Madruga R, Sokona Y, et al., editors. Climate change 2014: mitigation of climate change. Contribution of working group III to the ffth assessment report of the intergovernmental panel on climate change. Cambridge, and New York: Cambridge University Press; 2014. p. 811-922.

Sommer, S.G., Olesen, J.E., 1991. Effects of dry matter content and temperature on ammonia loss from surface-applied cattle slurry. Journal of Environmental Quality 20, 679-683.

Swierstra, D., Braam, C., Smits, M., 2001. Grooved floor system for cattle housing: Ammonia emission reduction and good slip resistance. Applied Engineering in Agriculture 17, 85.

Van den Pol, A., Blonk, H., Dolman, M.A., Evers, A.G., De Haan, M.H.A., Reijs, J.W., Sebek, L.B., Vellinga, T.V., Wemmenhove, H., 2013. Kosteneffectiviteit reductiemaatregelen emissie broeikasgassen zuivel. Wageningen UR Livestock Research.

van Dooren, H.J.C., Bokma, S., Ogink, N.W.M., 2019a. Ammoniakemissie tijdens frequent mixen van drijfmestmet lucht: Onderzoek op Dairy Campus. Wageningen Livestock Research.

van Dooren, H.J.C., Galama, P.J., Blanken, K., 2016. On farm development of bedded pack dairy barns in The Netherlands: gaseous emissions bedding. Wageningen Livestock Research. 
Van Dooren, H.J.C., Hol, J.M.G., Blanken, K., Galama, P.J., 2019b. Gasvormige emissies uit vrijloopstallen met houtsnipperbodems: ammoniak-, lachgas-en methaanemissie op stalniveau. Wageningen Livestock Research.

Van Kessel, C., Venterea, R., Six, J., Adviento-Borbe, M.A., Linquist, B., van Groenigen, K.J., 2013. Climate, duration, and N placement determine N2O emissions in reduced tillage systems: a metaanalysis. Global change biology 19, 33-44.

Van Middelaar, C., Berentsen, P., Dijkstra, J., De Boer, I., 2013. Evaluation of a feeding strategy to reduce greenhouse gas emissions from dairy farming: The level of analysis matters. Agricultural Systems 121, 9-22.

Vellinga, T., De Vries, M., 2018. Effectiveness of climate change mitigation options considering the amount of meat produced in dairy systems. Agricultural Systems 162, 136-144.

Vellinga, T.V., Reijs, J.W., Lesschen, J.P., Van Kernebeek, H.R., 2018. Lange termijn opties voor reductie van broeikasgassen uit de Nederlandse landbouw: Een verkenning. Wageningen Livestock Research.

Velthof, G.L., Rietra, R.P.J.J., 2018. Nitrous oxide emission from agricultural soils. Wageningen Environmental Research.

Verdoes, N., Bokma, S., 2017. Scheiding van urine en feces bij melkvee: fysiologie, gedragsherkenning en techniek. Wageningen Livestock Research.

Warner, D., Bannink, A., Hatew, B., Van Laar, H., Dijkstra, J., 2017. Effects of grass silage quality and level of feed intake on enteric methane production in lactating dairy cows. Journal of Animal Science 95, 3687-3699.

Willett, W., Rockström, J., Loken, B., Springmann, M., Lang, T., Vermeulen, S., Garnett, T., Tilman, D., DeClerck, F., Wood, A., 2019. Food in the Anthropocene: the EAT-Lancet Commission on healthy diets from sustainable food systems. The Lancet 393, 447-492.

Wollenberg, E., Richards, M., Smith, P., Havlík, P., Obersteiner, M., Tubiello, F.N., Herold, M., Gerber, P., Carter, S., Reisinger, A., 2016. Reducing emissions from agriculture to meet the $2 \mathrm{C}$ target. Global change biology 22, 3859-3864.

WRI, 2018. Half a Degree and a World Apart: The Difference in Climate Impacts Between $1.5^{\circ} \mathrm{C}$ and $2^{\circ} \mathrm{C}$ of Warming. World Resource Institute (WRI). 
Wageningen Economic Research P.O. Box 29703

2502 LS The Hague

The Netherlands

$\mathrm{T}+31(0) 703358330$

E communications.ssg@wur.nl

www.wur.eu/economic-research

Wageningen Economic Research REPORT

2021-105
The mission of Wageningen University \& Research is "To explore the potential of nature to improve the quality of life". Under the banner Wageningen University \& Research, Wageningen University and the specialised research institutes of the Wageningen Research Foundation have joined forces in contributing to finding solutions to important questions in the domain of healthy food and living environment. With its roughly 30 branches, $6,800$ employees ( $6,000 \mathrm{fte})$ and 12,900 students, Wageningen University \& Research is one of the leading organisations in its domain. The unique Wageningen approach lies in its integrated approach to issues and the collaboration between different disciplines.

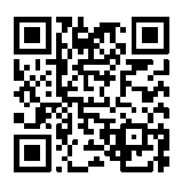





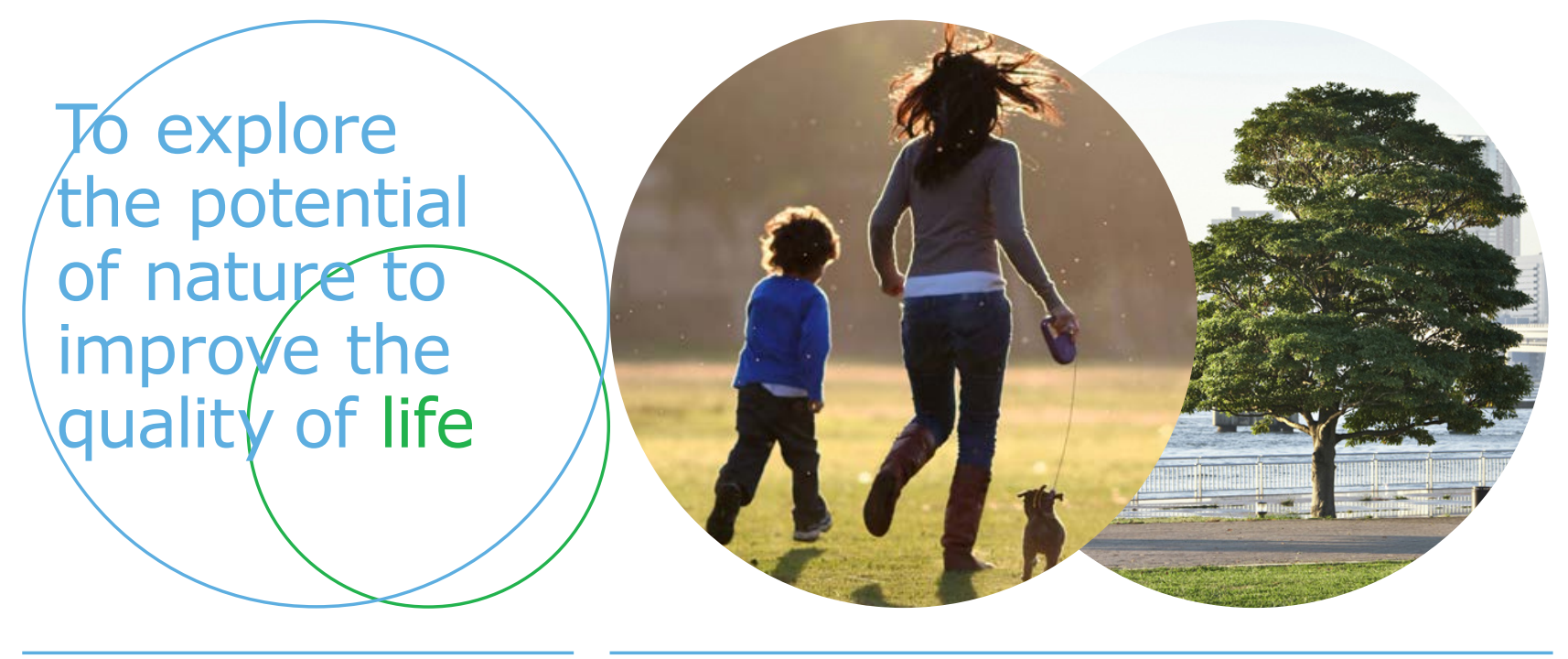

Wageningen Economic Research P.O. Box 29703

2502 LS Den Haag

The Netherlands

$\mathrm{T}+31(0) 703358330$

E communications.ssg@wur.nl

www.wur.eu/economic-research

Report 2021-105

ISBN 978-94-6395-992-6
The mission of Wageningen University \& Research is "To explore the potential of nature to improve the quality of life". Under the banner Wageningen University \& Research, Wageningen University and the specialised research institutes of the Wageningen Research Foundation have joined forces in contributing to finding solutions to important questions in the domain of healthy food and living environment. With its roughly 30 branches, 6,800 employees (6,000 fte) and 12,900 students, Wageningen University \& Research is one of the leading organisations in its domain. The unique Wageningen approach lies in its integrated approach to issues and the collaboration between different disciplines. 